\title{
Anadromous Salmonids of the Hanford Reach, Columbia River: 1984 Status
}

C. D. Becker

September 1985

Prepared for the U.S. Department of Energy under Contract DE-AC06-76RLO 1830

Pacific Northwest Laboratory Operated for the U.S. Department of Energy by Battelle Memorial Institute 


\title{
DISCLAIMER
}

This report was prepared as an account of work sponsored by an agency of the United States Government. Neither the United States Government nor any agency thereof, nor any of their employees, makes any warranty, express or implied, or assumes any legal liability or responsibility for the accuracy, completeness, or usefulness of any information, apparatus, product, or process disclosed, or represents that its use would not infringe privately owned rights. Reference herein to any specific commercial product, process, or service by trade name, trademark, manufacturer, or otherwise, does not necessarily constitute or imply its endorsement, recommendation, or favoring by the United States Government or any agency thereof. The views and opinions of authors expressed herein do not necessarily state or reflect those of the United States Government or any agency thereof.

\author{
PACIFIC NORTHWEST LABORATORY \\ operated by \\ BATTELLE \\ for the \\ UNITED STATES DEPARTMENT OF ENERGY \\ under Contract DE-AC06-76RLO 1830
}

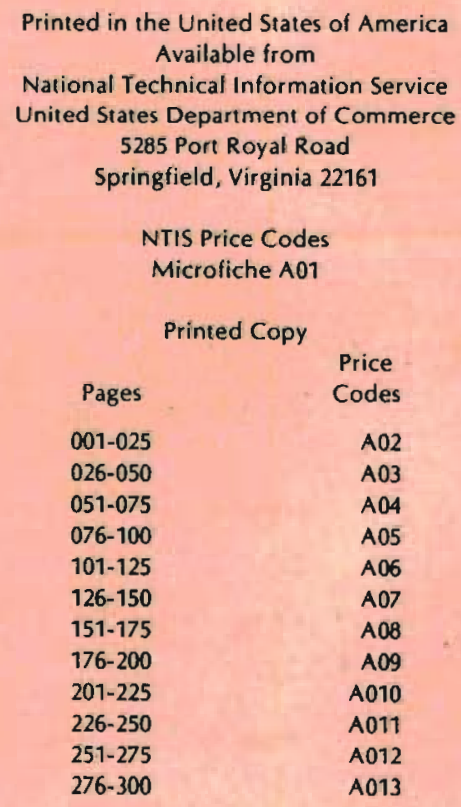


ANADROMOUS SALMONIDS OF THE HANFORD REACH, COLUMBIA RIVER: 1984 STATUS

C. D. Becker

September 1985

Prepared for

the U.S. Department of Energy

under Contract DE-AC06-76RLO 1830

Pacific Northwest Laboratory

Richland, Washington 99352 


\section{ACKNOWLEDGMENTS}

The author, as well as the text, benefited from erudite reviews provided by PNL scientists Dennis D. Dauble, Duane H. Fickeisen, Duane A. Neitzel, and Thomas L. Page. Other suggestions leading to manuscript improvement were kindly submitted by James W. Mullan, USFWS, Leavenworth National Fish Hatchery, Leavenworth, Washington; Don E. Weitkamp, Parametrix Inc., Bellevue, Washington; and Mike B. De11, Grant County Public Utility District, Ephrata, Washington. Suzanne F. Liebetrau of PNL provided editorial support. 
SUMMARY

The Hanford Reach, a regulated but flowing section of the Columbia River, supports spawning populations of fall chinook salmon (Oncorhynchus tshawytscha) and steelhead (Salmo gairdneri). It also serves as a migration route for upriver runs of chinook, coho ( $\underline{0}$ kisutch) and sockeye ( $\underline{0}$. nerka) salmon, and of steelhead. Environmental studies conducted in association with activities on the Hanford Site provide a basis for assessing present ecological conditions in the Hanford Reach. Spawning populations of fall chinook salmon at Hanford increased dramatically after 1960, when Priest Rapids Dam was completed, and have remained relatively stable since 1969. Numbers of adult salmonids that traverse the Hanford Reach to upriver spawning areas have varied in recent years. Generally, upriver runs of spring, summer, and fall chinook salmon have been depressed, but the fall run has been increasing since 1980. Runs of coho salmon have fallen concomitant with cutbacks in hatchery production, particularly since 1976 . Runs of sockeye salmon declined after 1968 to about 40,000 fish annually, but surged upward in 1983 and 1984. An extensive hatchery program has helped maintain upriver runs of steelhead, which also surged upward in 1983 and 1984.

Habitat modification represents the greatest threat to sustained production of fall chinook salmon in the Hanford Reach. Operations on and near the Hanford Site, such as various research and development work for the U.S. Department of Energy, releases of small amounts of radioactivity from onsite operations to river and groundwater, and operation of a steam electric plant, can have negligible effects on salmonids and other aquatic resources. Possible activities with potential for future impacts include development of a multi-unit power plant complex at Hanford, construction of a low-head hydroelectric dam above Richland, flow fluctuations from peaking power generation at Priest Rapids Dam, irrigation and reductions of instream flows, and dredging and commercial navigation above Hanford. If reproducing populations of fall chinook salmon and steelhead are to survive in the mid-Columbia River, the Hanford Reach must remain flowing, undeveloped for navigation, and with unimpaired water quality. 


\section{CONTENTS}

ACKNOWLEDGMENTS

iij

SUMMARY

$\checkmark$

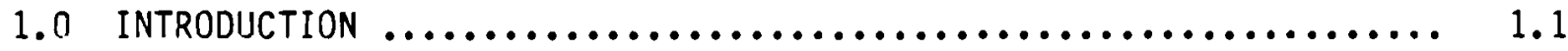

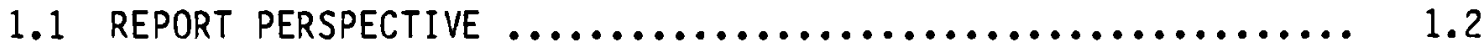

1.2 HISTORICAL PERSPECTIVE $\ldots \ldots \ldots \ldots \ldots \ldots \ldots \ldots \ldots \ldots \ldots \ldots \ldots \ldots \ldots \ldots \ldots \ldots \ldots$

2.0 THE HANFORD REACH OF THE COLUMBIA RIVER $\ldots \ldots \ldots \ldots \ldots \ldots \ldots \ldots \ldots \ldots$

2.1 GENERAL DESCRIPTION $\ldots \ldots \ldots \ldots \ldots \ldots \ldots \ldots \ldots \ldots \ldots \ldots \ldots \ldots \ldots \ldots \ldots \ldots \ldots \ldots$

2.2 PHYSICAL CHARACTERISTICS $\ldots \ldots \ldots \ldots \ldots \ldots \ldots \ldots \ldots \ldots \ldots \ldots . \ldots \ldots$

2.2.1 River Flows $\ldots \ldots \ldots \ldots \ldots \ldots \ldots \ldots \ldots \ldots \ldots \ldots \ldots . \ldots \ldots$

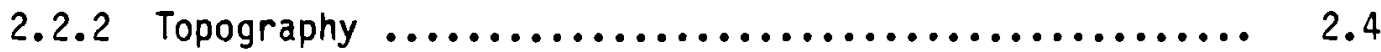

2.2 .3 Water Quality $\ldots \ldots \ldots \ldots \ldots \ldots \ldots \ldots \ldots \ldots \ldots \ldots . \ldots \ldots$

2.2.4 Suspended Materials .................... 2.8

2.2.5 Water Temperatures $\ldots \ldots \ldots \ldots \ldots \ldots \ldots \ldots \ldots \ldots \ldots \ldots . \ldots \ldots$

3.0 SALMONID POPULATIONS $\ldots \ldots \ldots \ldots \ldots \ldots \ldots \ldots \ldots \ldots \ldots \ldots \ldots \ldots \ldots \ldots \ldots \ldots \ldots \ldots \ldots$

3.1 CHINOOK SALMON $\ldots \ldots \ldots \ldots \ldots \ldots \ldots \ldots \ldots \ldots \ldots \ldots \ldots \ldots \ldots \ldots \ldots \ldots \ldots . \ldots \ldots$

3.1 .1 Fall-Run Adults $\ldots \ldots \ldots \ldots \ldots \ldots \ldots \ldots \ldots \ldots \ldots . \ldots . \ldots . \ldots$

3.1.2 Spring-Run and Summer-Run Adults $\ldots \ldots \ldots \ldots \ldots \ldots \ldots . . \ldots \ldots$

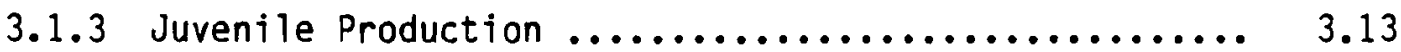

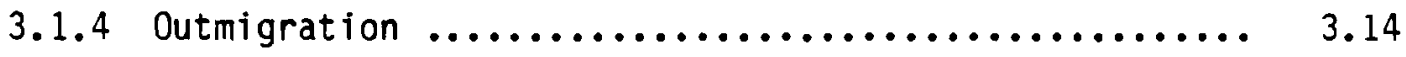

3.1.5 Fish Releases $\ldots \ldots \ldots \ldots \ldots \ldots \ldots \ldots \ldots \ldots \ldots \ldots \ldots \ldots . . \ldots . \ldots$

3.2 COHO SALMON $\ldots \ldots \ldots \ldots \ldots \ldots \ldots \ldots \ldots \ldots \ldots \ldots \ldots \ldots \ldots \ldots \ldots \ldots . \ldots \ldots$

3.2 .1 Adults $\ldots \ldots \ldots \ldots \ldots \ldots \ldots \ldots \ldots \ldots \ldots \ldots \ldots \ldots \ldots \ldots \ldots . \ldots . \ldots . \ldots . \ldots$

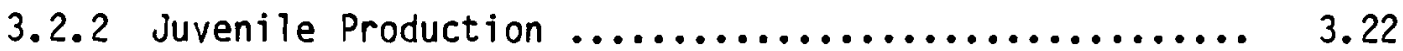

3.2 .3 Dutmigration $\ldots \ldots \ldots \ldots \ldots \ldots \ldots \ldots \ldots \ldots \ldots \ldots \ldots \ldots . \ldots \ldots \ldots$

3.2.4 Fish Releases ........................... 3.24 
3.3 SOCKEYE SALMON $\ldots \ldots \ldots \ldots \ldots \ldots \ldots \ldots \ldots \ldots \ldots \ldots \ldots \ldots, \quad 3.24$

3.3 .1 Adults ................................... 3.24

3.3.2 Juvenile Production $. . \ldots \ldots \ldots \ldots \ldots \ldots \ldots \ldots \ldots . .6 .25$

3.3 .3 Outmigration $\ldots \ldots \ldots \ldots \ldots \ldots \ldots \ldots \ldots \ldots \ldots \ldots \ldots, 3.26$

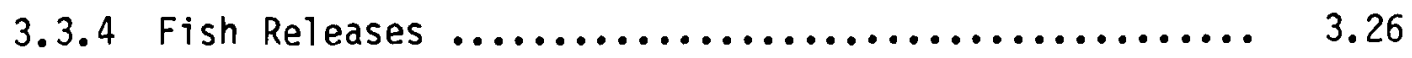

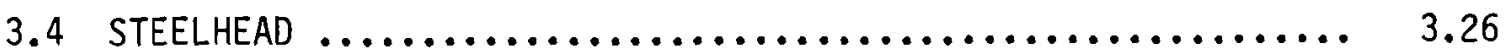

3.4 .1 Adults .................................... 3.26

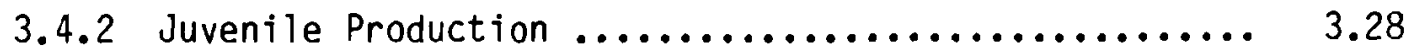

3.4 .3 Outmigration $\ldots \ldots \ldots \ldots \ldots \ldots \ldots \ldots \ldots \ldots \ldots . . . \ldots \ldots$

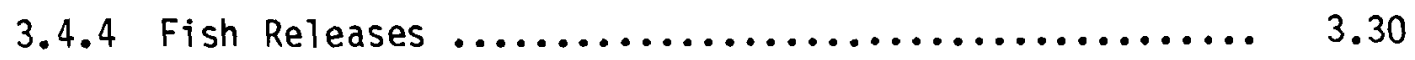

4.0 POTENTIAL HABITAT MODIFICATIONS $\ldots \ldots \ldots \ldots \ldots \ldots \ldots \ldots \ldots \ldots, 4.1$

4.1 HANFORD SITE ACTIVITIES $\ldots \ldots \ldots \ldots \ldots \ldots \ldots \ldots \ldots \ldots \ldots, 4.1$

4.1.1 Direct Releases of Heat and Radionuclides to the River ..................................... 4.2

4.1.2 Indirect Releases of Radionuclides

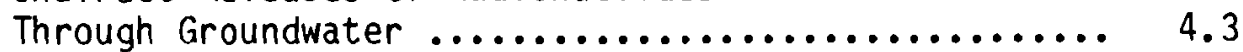

4.1.3 Operation of a Steam-Electric Plant ............. 4.4

4.1.4 Multi-Unit Power Plant Complex at Hanford .......... 4.5

4.2 REgIONAL ACTIVITIES $\ldots \ldots \ldots \ldots \ldots \ldots \ldots \ldots \ldots \ldots \ldots \ldots, 4.6$

4.2.1 Peaking Power Generation at Upriver Dam ........... 4.6

4.2.2 Potential Hydroelectric Dam on the Hanford Reach .... 4.7

4.2.3 Irrigation and Instream Flow Reduction $\ldots \ldots \ldots \ldots \ldots . .4$

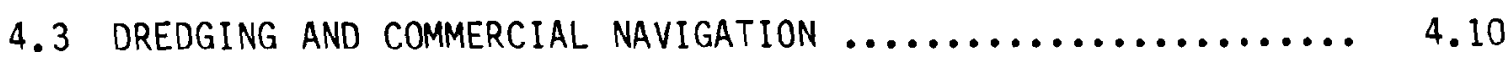

5.0 ASSESSMENT $\ldots \ldots \ldots \ldots \ldots \ldots \ldots \ldots \ldots \ldots \ldots \ldots \ldots \ldots \ldots \ldots \ldots \ldots . \ldots \ldots . \ldots \ldots$

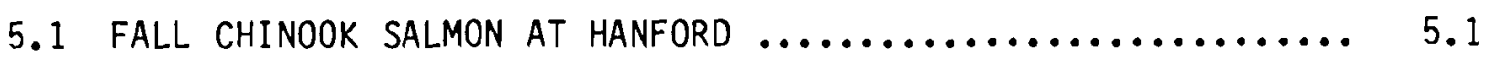

5.2 EFFECTS ON THE HANFORD REACH $\ldots \ldots \ldots \ldots \ldots \ldots \ldots \ldots \ldots \ldots \ldots . \ldots \ldots$

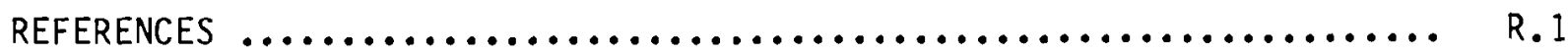

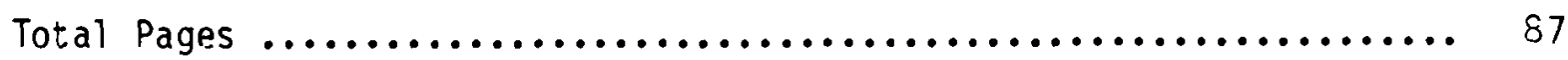




\section{FIGURES}

1.1 Chinook Salmon, Oncorhynchus tshawytscha $\ldots \ldots \ldots \ldots \ldots \ldots \ldots \ldots . . \ldots 1$

2.1 Hanford Reach of the Mid-Columbia River in Washington State ..... 2.2

2.2 Schematic View of Distance and Elevation of the Hanford

Reach in Relation to Mainstem Columbia River Dams ............. 2.2

2.3 Columbia River Daily Flow Patterns at Priest Rapids Dam, May Through August 1976-1977

2.4 Results of Monitoring the Quality of Columbia River Water

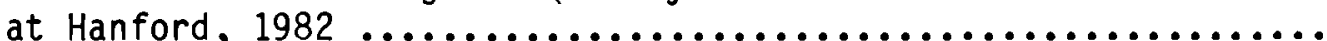

2.5 Mean, Maximum and Minimum Daily Columbia River Water Temperatures at Priest Rapids Dam, 1960-1977 ........... 2.11

3.1 Life Cycle of Anadromous Fall Chinook Salmon Associated with the Hanford Reach

3.2 Seasonal Distribution of Anadromous Salmonids Using the Hanford Reach ......................................

3.3 Relative Abundance of Fall Chinook Salmon Redds in the Hanford Reach, 1947 through 1981

3.4 Major Spawning Areas Used by Fall Chinook Salmon in the Hanford Reach

3.5 Outmigration Pattern of Juvenile Spring Chinook and Sockeye Salmon and Steelhead Trout at Priest Rapids Dam in 1982

3.6 Releases of Juvenile Fall Chinook Salmon from Priest Rapids Rearing Facilities 1962-1983

3.7 Releases of Juvenile Chinook Salmon from Ringold Rearing Facilities

3.8 Likely Spawning Areas for Steelhead in the Hanford Reach ....... 3.29

3.9 Releases of Juvenile Steelhead from Ringold Rearing Facilities

5.1 Assessment of Effects from Present or Potential Activities on Salmonid Resources of the Hanford Reach, Based on Life Cycle Phase and Environment 


\section{TABLES}

2.1 Water Quality Standards for the Hanford Reach of the Columbia River ................................... 2.6

2.2 Quality Characteristics of Columbia River Water at Vernita Bridge, Above the Hanford Reach, October 1977 to October 1980

3.1 Annual Estimates of Adult Fall Chinook Salmon in the Mid-Columbia River Since 1960 ........................... 3.6

3.2 Counts of Adult Salmonids at the Fishway of Priest Rapids Dam ................................. 3.7

3.3 Distribution of Fall Chinook Salmon Redds in the Hanford Reach by Major Spawning Area ......................... 3.11

3.4 Peak Outmigration Dates for Juvenile Salmonids at Priest Rapids Dam, and Their Percent Relative Abundance for Years Where Data Are Comparable

3.5 Estimated Numbers of Salmonid Smolts Passing Downstream at Priest Rapids Dam 1965-1983, Where Data Are Available 


\subsection{INTRODUCTIUN}

The Hanford Reach is the last unimpounded section of the mainstem Columbia River above Bonneville Dam. For this reason, the Hanford Reach represents "remnant habitat," a survivor of the river's past. Although regulated by operation of Priest Rapids Dam, the Hanford Reach remains flowing and retains many seasonal flow characteristics. The Hanford Reach contributes substantialiy to upriver runs of fall chinook saimon (Oncorhynchus tshawytscha, Figure 1.1) in the Columbia River. It is also used for spawning by steelhead (Salmo gairdneri) and by other species of anadromous fish as an upstream and downstream migration route.

The Hanford Reach lies primarily within or adjacent to the Hanford Site, 1,476 square kilometers in southeastern Washington that have been maintained since 1943 by the Federal government. A number of energy, defense, and other programs that support national needs are conducted at Hanford. Environmental requirements of salmonids and other aquatic resources of the Hanford Reach are considered in the planning and operational phases of these programs.

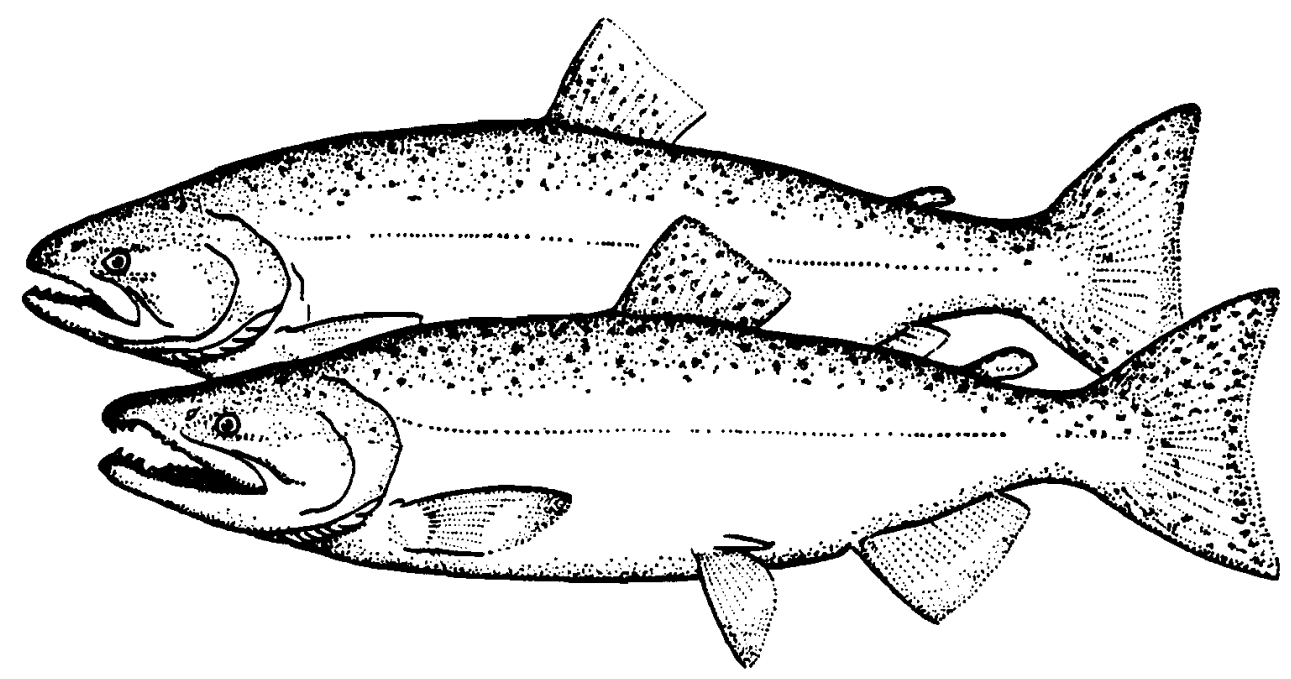

FIGURE 1.1. Chinook Salmon, Oncorhynchus tshawytscha 


\subsection{REPORT PERSPECTIVE}

The objectives of this report are to describe the anadromous salmonid resources of the Hanford Reach, and to evaluate the effect of human activities on long-term maintenance of these resources.

The report is organized into three sections. The first section describes existing ecological features of the Hanford Reach, with emphasis on those features that influence the abundance of anadromous fish. The second section describes populations of fall chinook salmon, coho salmon (‥ kisutch), sockeye salmon ( ${ }^{0}$ nerka) , and steelhead that use or pass through the Hanford Reach. The third section reviews current activities and possible future actions with potential for adverse effects on anadromous salmonid populations of the Hanford Reach.

\subsection{HISTORICAL PERSPECTIVE}

Due to heavy exploitation, the sizes of anadromous salmon runs to the Columbia River were greatly reduced prior to the construction of Bonneville Dam near the river outlet in 1938 (Smith 1979; Seufert 1980; Chapman et al. 1982). Since then, development of hydroelectric power and water storage projects throughout the Columbia River system has reduced the spawning and rearing habitat for anadromous salmonids from 422,688 to 187,205 square kilometers (Salo and Stober 1977). The creation of large pools behind the series of dams represents loss of spawning areas, which has contributed directly to the reduction of anadromous salmonid stocks (Brockson et al. 1982). The resource has never recovered its natural reproductive potential.

Other impacts on salmon and steelhead are associated with Columbia River dams and their operation. These impacts are listed below.

- mortality of juvenile outmigrants (smolts) in power-generating turbines (Cramer and 01igher 1964; Ebel 1977; Turbak et al. 1981)

- mortality from nitrogen supersaturation (Ebel 1969; Meekin and Allen 1974; Ebel et al. 1975; Weitkamp and Katz 1980)

- blockage of upstream migrations, particularly at Grand Coulee Dam (Fulton 1968, 1970) 
- predation (Thompson 1959; Brown and Moyle 1981; Gray et al. 1984)

- delay in timing adult and smolt migrations (French and Wahle 1966; Raymond 1968, 1969, 1979; Collins et al. 1975; Bentley and Raymond 1976; Monan and Liscom 1976)

- transmission of infectious disease agents in fish passage facilities (Fujihara and Hungate 1971; Becker and Fujihara 1978).

In addition, dams and their reservoirs alter many different physical characteristics of a river (Baxter 1977; Baxter and Claude 1980; Brockson et a1. 1982; Ward and Stanford 1979).

Assessment of the salmonid stocks today indicates that the effects have increased with the addition of each new dam, while the resiliency of the various species has steadily declined (Salo and Stober 1977). Reduction in stock sizes has been accompanied by strong, even increased, fishing pressure (Chapman et al. 1982).

Beginning with the development of fish passage facilities at dams, over 35 years of effort have been extended to prevent declines in anadromous salmon runs in the Columbia River system (Netboy 1974). Subsequent mitigation efforts have included an extensive hatchery program supported by the Federal government and the states of Washington, Oregon, and Idaho (Armacost 1979; Kaczynski and Moos 1979). As a result, unique up-river stocks of naturally spawning salmonids have been replaced through mass production of fish with common life histories, morphology and genetic characteristics. The production of hatchery and wild salmonids in the Columbia River system is now about 50:50, and it is important that the remaining wild stocks be conserved (Salo and Stober 1977).

Populations of anadromous salmonids in the Columbia River above the Bonneville pool today are largely dependent on hatchery production, and their status remains tenuous. Since the Hanford Reach provides the only natural spawning area for anadromous salmonids in the mainstem Columbia River, adverse impacts must be avoided. Existing environmental regulations make attainment of this goal possible. 


\subsection{THE HANFORD REACH OF THE COLUMBIA RIVER}

The abiotic and biotic environment that sustains anadromous salmonids in the mid-Columbia River is now well characterized, largely because of Federal regulatory requirements (Greenwood et al. 1979). The National Environmental Policy Act (NEPA) of 1969, for example, stipulates that all environmental consequences of Federal actions must be considered and evaluated. As a result, information on the aquatic ecology of the Hanford Reach is now extensive (e.g., U.S. ERDA 1975; U.S. IRC 1975; Page et al. 1976; Gray et al. 1976; WPPSS 1977; Gray and Page 1977, 1978, 1979a, 1979b; Beak Consultants, Inc. 1980; Fickeisen et al. 1980; Neitzel et al. 1982a, 1982b; Page et al. 1982; Puget Power 1982; Rickard et al. 1982; U.S. DOE 1982).

\subsection{GENERAL DESCRIPTION}

The Hanford Reach of the Columbia River extends 94 kilometers from Priest Rapids Dan at River Kilometer (RKM) 639 downstream to the city of Richland (RKM 545) in southcentral Washington. The Hanford Reach runs through the northern part of the Hanford Site and along its eastern border (Figure 2.1). The Snake River and Yakima River join the Columbia River below Richland, and the combined flows enter Lake Wallula behind McNary Dam.

The Columbia River drains about 249,000 square kilometers (96,000 square miles) above Hanford. Seven dams extend from the Canadian border downstream to the Hanford Reach (Figure 2.2), and other dams are located in Canada. The dams were built primarily to provide hydroelectric power, water for irrigation, and flood control.

The Hanford Reach passes through a semi-arid plateau at about 130 meters (426 feet) above mean sea level. Summer maximum temperatures have varied from $37.8^{\circ}$ to $46.1^{\circ} \mathrm{C}\left(100^{\circ}\right.$ to $\left.115^{\circ} \mathrm{F}\right)$, while winter minima vary from $-47^{\circ}$ to $-5.6^{\circ} \mathrm{C}$ $\left(-27^{\circ}\right.$ to $+22^{\circ} \mathrm{F}$ ) (Stone et al. 1983). Hanford lies in the rain shadow of the Cascade Mountains, and annual precipitation averages 15.9 centimeters (6.25 inches). The wettest period, through November, December and January, provides $44 \%$ of the total annual precipitation; the driest period, July, August and September, provides only $12 \%$. 

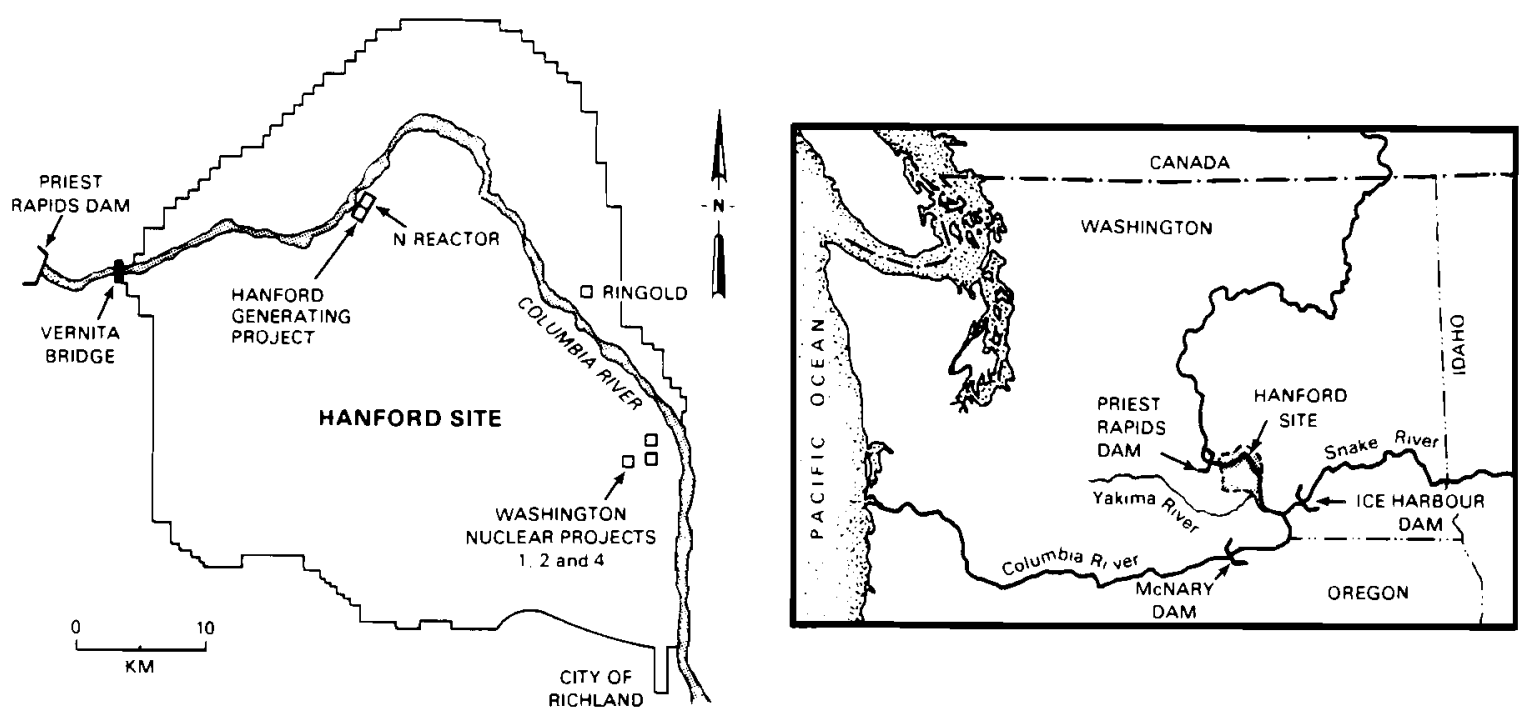

FIGURE 2.1. Hanford Reach of the Mid-Columbia River in Washington State (Only dams directly above and below Hanford are shown)

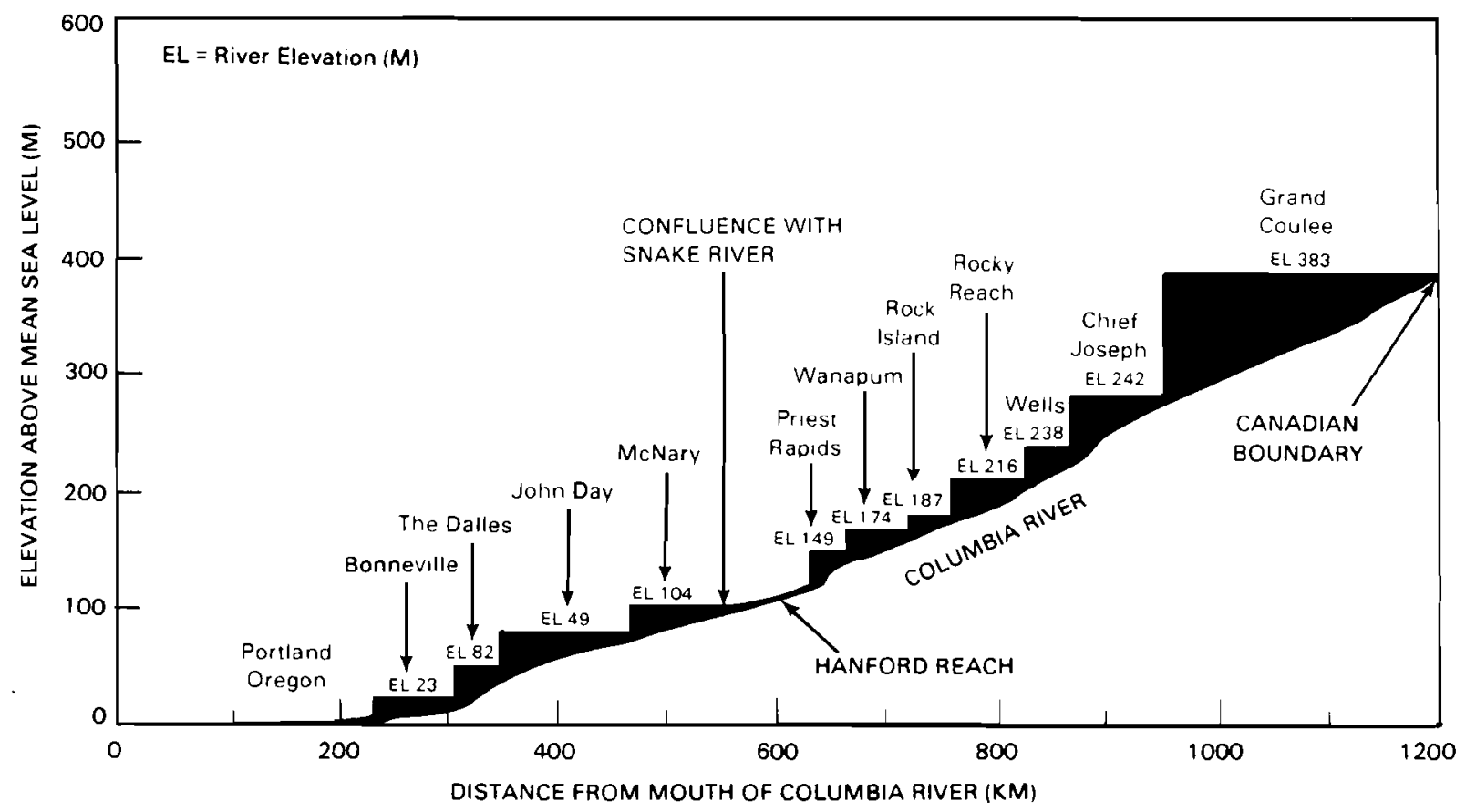

FIGURE 2.2. Schematic View of Distance and Elevation of the Hanford Reach in Relation to Mainstem Columbia River Dams (after U.S. ACOE 1976) 


\subsection{PHYSICAL CHARACTERISTICS}

The physical characteristics of the Hanford Reach are those of a regulated but flowing river that carries relatively large amounts of water from an extensive drainage basin.

\subsubsection{River Flows}

River flows in the Hanford Reach vary with seasonal runoff and powerpeaking operations at Priest Rapids Dam (Whelan and Newbill 1983). The average daily discharge may range from 1,020 cubic meters per second $(36,000$ cubic feet per second), the minimum legal flow set by the Federal Energy Regulatory Commission, to as much as 4,530 cubic meters per second $(160,000$ cubic feet per second). Peak seasonal flows are due to melting of winter snowpack during June and July, augmented by local rainfall. Average daily discharges of 4350 cubic meters per second to as much as 18,418 cubic meters per second $(650,000$ cubic feet per second) have been recorded during spring runoff (U.S. ERDA 1975). The 55-year average daily flow rate for the Hanford Reach is 3,422 cubic meters per second $(120,800$ cubic feet per second). However, flows average around 2,266 cubic meters per second $(80,000$ cubic feet per second) or less during late summer and early fall (U.S. ERDA 1975).

Today, flow extremes are greatly moderated by the reservoir complex above Hanford, particularly during the annual spring runoff. The mean monthly volume of water passing Priest Rapids Dam from March through July, 1960 through 1970, was $61 \%$ of the mean annual volume, but this decreased to 53\% from 1971 through 1979. Also, the high June flows that formerly accounted for $21 \%$ of the annual volume have decreased to $13 \%$. The reservoir complex, therefore, has reduced the historical annual discharge pattern so that a constant flow regime is being approached (Dewaard 1981).

The width and depth of the Columbia River at Hanford vary with location and discharge volume. Width extends from 365 to 548 meters $(1,200$ to 1,800 feet). Midchannel depth varies from 9 to 14 meters (30 to 46 feet). River flows fluctuate daily but the range is variable (Figure 2.3). River elevation may vary as much as 3 meters (10 feet) daily in the upper part of the Hanford Reach and 1.5 meters ( 5 feet) further downstream when power generation at 


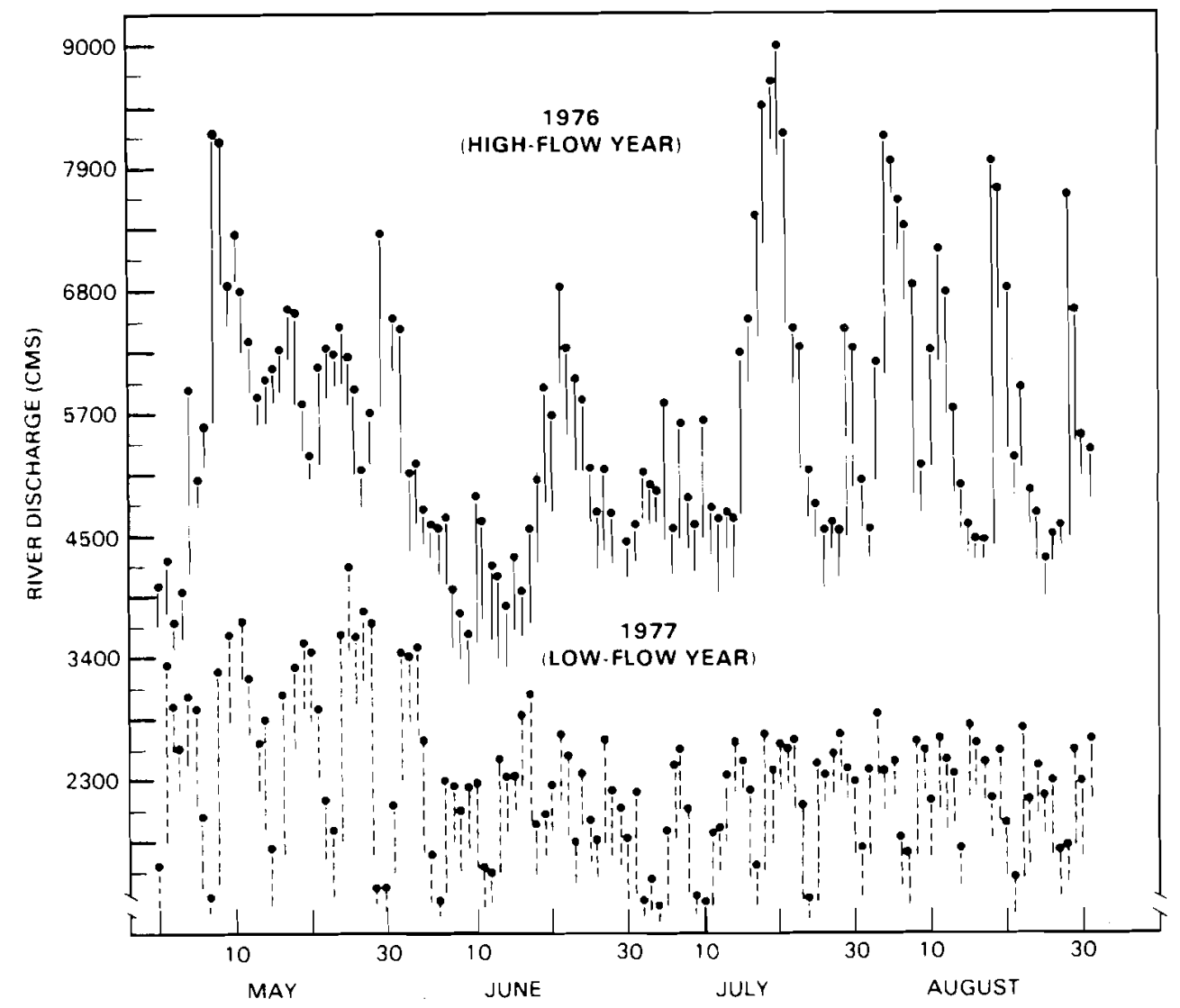

FIGURE 2.3. Columbia River Daily Flow Patterns (spill plus turbine discharge) at Priest Rapids Dam, May Through August 1976-1977 (daily and weekly variations in discharge are due to hydroelectric generation in response to power demand; after Becker et a1. 1981)

Priest Rapids Dam responds to changed consumer demand (U.S. ERDA 1975). These fluctuations cause frequent, short-term flooding and dewatering of the shoreline.

Current velocities vary from less than 0.9 to over 3.35 meters per second ( 3 to 11 feet per second), depending on flow stage and location. Maximum surface velocities occur near midstream during the spring spate (U.S. ERDA 1975).

\subsubsection{Topography}

The upper section of the Hanford Reach, from Priest Rapids to Coyote Rapids (RKM 616), is a deep, U-shaped channel with uniform features. From this point downstream to the city of Richland, the channel of the Hanford Reach is 
braided around islands, submerged rock ledges and gravel bars, causing repeated pooling and channeling (U.S. ERDA 1975). The river bed typically consists of sand, gravel, cobble and large rock up to 20 centimeters ( 8 inches) in diameter. Sections of the steam bed include Ringold formation substrate, a conglomerate of clay, sand, gravel, and rock. Much of the shoreline is steep and includes a narrow cobble strip. Twenty-one islands are present, with cobble and/or sandy shorelines (Fickeisen et al. 1980).

The shoreline and islands in the Hanford Reach vary in expanse according to their slopes and river stages. Large cobblestone beaches occur on very gentle slopes or flat islands. The cobblestone areas are subject to frequent water-level changes, and are kept free of overburden by currents. The vegetation of the cobblestone areas consists mainly of hardy, water-tolerant perennial forbs and grasses that grow profusely during the summer low-flow period. Additionally, four large slough areas with shallow basins and deposits of silt support a rich assembly of riparian forbs and grasses, including cattails (Typha latifolia), reed canary grass (Phalaris arundinacea), and spikerush (Eleocharis palustris). Sandbar willow (Salix exigua) grows in scattered patches along the fringes of the high-water mark.

The cobblestone substrate and associated riparian plant communities of the Hanford Reach are unique in the Columbia River ecosystem (Fickeisen et al. 1980). The physical characteristics and shoreline communities of impoundments above and below Hanford are considerably different.

\subsubsection{Water Quality}

The Washington State Department of Ecology (WSDOE) has designated the Hanford Reach as Class A, or excellent, for water quality requirements. This designation requires that industrial uses of the river be compatible with all other uses of the water, including drinking water, recreation and wildiife (WSDOE 1977). State standards are identified in Table 2.1.

The Columbia River Basin of eastern Washington has been developed primarily for agriculture. Water quality might be impaired by return flows of irrigation water containing fertilizers, insecticides and herbicides, by 
TABLE 2.1. Water Quality Standards for the Hanford Reach of the Columbia River

Parameter

Fecal coliform
bacteria
Dissolved oxygen
Temperature
pH
Turbidity
Toxic, radioactive,
or deleterious
material

Aesthetic value
Permissible Levels

1. $<100$ organisms $/ 100 \mathrm{~mL}$ (median)

2. $610 \%$ of samples may exceed 20 organisms $/ 100 \mathrm{~mL}$ $\geqslant 8 \mathrm{mg} / \mathrm{L}$

1. $\quad 620 \mathrm{C}(68 \mathrm{~F})$ due to human activity

2. Increases not to exceed $34 /(T+9)$ where $T=$ highest existing temperature in $C$ outside of mixing zone.

1. 6.5 to 8.5 range

2. $<0.5$ unit induced variation $\leqslant 5$ NTU (Nephelometric Turbidity Units - standard candle) over background turbidity

Concentration shall be below those of public health significance, or which cause acute or chronic conditions to aquatic biota, or which may adversely affect water use.

Shall not be impaired by the presence of materials and their effects, excluding those of natural origin, which offend the senses of sight, touch or taste.

Source: After Washington State Department of Ecology 1977.

industrial wastes and domestic sewage discharges, and by silt from soil erosion. Water quality in Basin streams was examined from 1951 to 1953 (Robeck et al. 1954) and from 1954 to 1957 (Sylvester 1959). The data revealed no significant change in water quality, and indicated that future impoundments formed in the main Columbia River would not alter chemical and physical parameters sufficiently to harm aquatic life (Sylvester 1959). This conclusion proved to be essentially correct. Quality of water in the mid-Columbia River remains high today (WSDOE 1977).

The cities of Richland and Pasco obtain most of their municipal water, and the city of Kennewick obtains about $40 \%$ of its total, from the Columbia River downstream from Hanford. The combined population for the Tri-Cities is near 90,000 (Price et al. 1984).

Water quality has been routinely monitored at Hanford for many years by the U.S. Geological Survey, and by a site surveillance group on the Hanford 
Site. Present conditions are represented by data taken from 0ctober 1977 to October 1980 (Table 2.2). Generally, dissolved solids range from 73 to $120 \mathrm{mg} / \mathrm{L}$, and hardness varies from 65 to $85 \mathrm{mg} / \mathrm{L}$. Dissolved oxygen (DO) levels range from about 8 to $13 \mathrm{mg} / \mathrm{L}$, average $11.0 \mathrm{mg} / \mathrm{L}$, and are usually near saturation (U.S. DOE 1982). Coliform bacteria range from 4 to 75 per 100 milliliters

TABLE 2.2. Quality Characteristics of Columbia River Water at Vernita Bridge, Above the Hanford Reach, October 1977 to October 1980

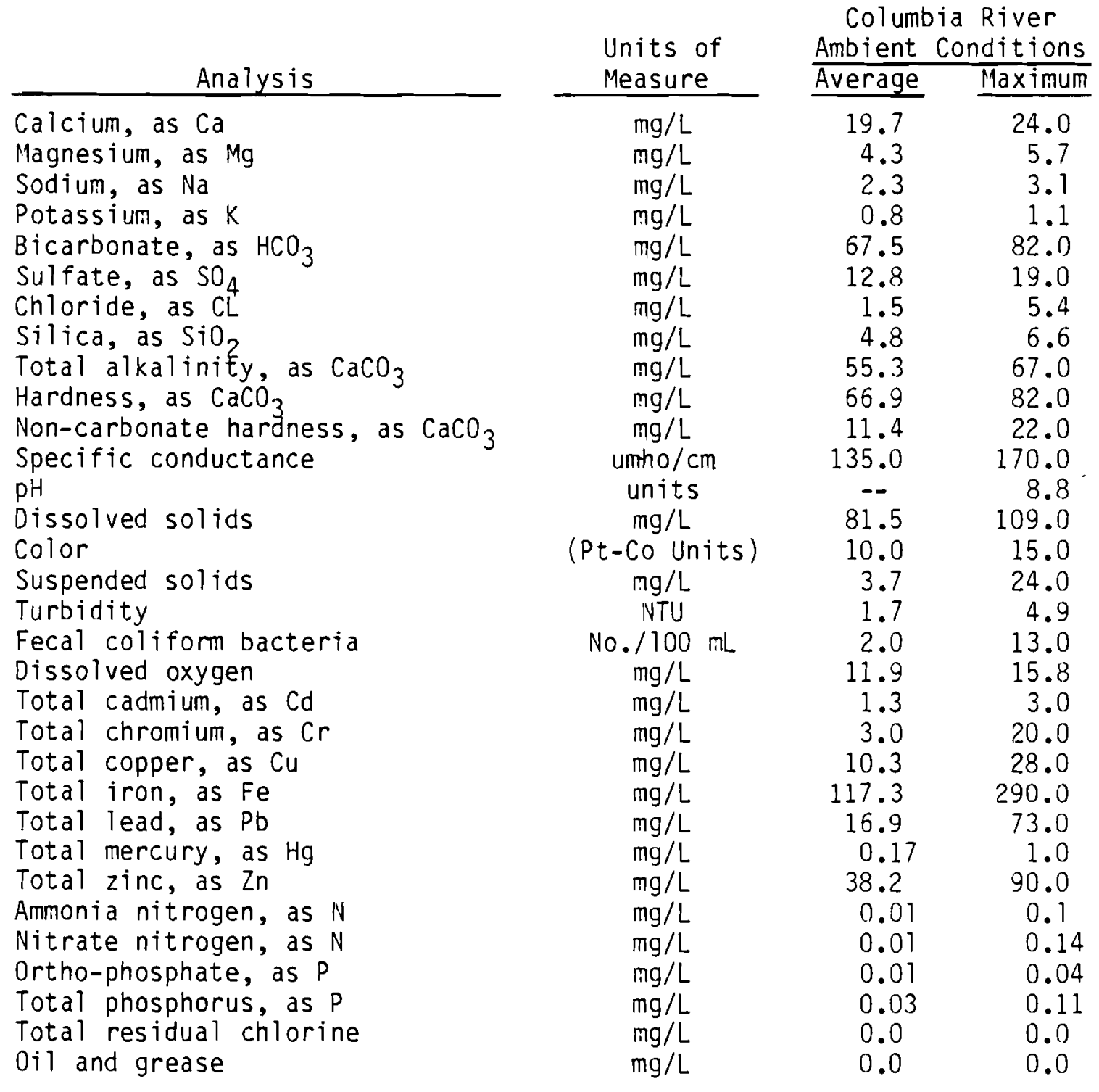

Source: After Puget Power 1982. 
of water below Priest Rapids Dam and average about 30 per 100 milliliters. Turbidity in the Hanford Reach is generally less than 5 Jackson Turbidity Units. The river water is alkaline at $\mathrm{pH} 8$ to 8.5 .

Activities on the Hanford Site conform to federal and state standards designed to protect environmental quality. Each waste water discharge from various operations at Hanford has an applicable EPA permit. Water quality measurements are taken above and below Hanford to detect any affects attributable to onsite work, and to determine compliance with Class A designation requirements. Sampling in 1982 and 1983 indicated no substantial deterioration in water quality from activities at Hanford (Sula et al. 1983; Price et al. 1984). However, state water quality standards for fecal coliform bacteria, pH, and low dissolved oxygen were sometimes exceeded in river water above and in the Hanford Reach (Figure 2.4). Thus, exogenous factors can impair onsite water quality.

\subsubsection{Suspended Materials}

Concentrations of suspended sediment vary widely in the Hanford Reach because inputs from upriver tributaries vary seasonally (U.S. ERDA 1975). Columbia River reservoirs intercept much of the suspended material during low river flows, but some of the deposits are resuspended and washed downstream during high flows (Whetten et al. 1969; Robertson and Fix 1977).

Suspended material in river water ranges from $300 \mathrm{~g} / \mathrm{L}$ in November to $35,000 \mathrm{~g} / \mathrm{L}$ in April, or nearly a hundredfold variation annually (Wildung et al. 1972). The portion of suspended particles $<0.5$ microns diameter exceeds $50 \%$ during the spring spate, reflecting redistribution and downstream passage of fine materials. At other seasons, suspended particles from 2.0 to 5.3 microns in diameter predominate $(>70 \%)$. The total carbon content of suspended material is least in the spring and greatest in the fall, which probably reflects the increased seasonal production of phytoplankton (Wildung et al. 1972; Neitzel et al. 1982a).

Deposition of water-borne materials in the Hanford Reach is limited because of strong currents. Therefore, the gravel composition of the stream bed probably remains similar to that existing centuries ago. 

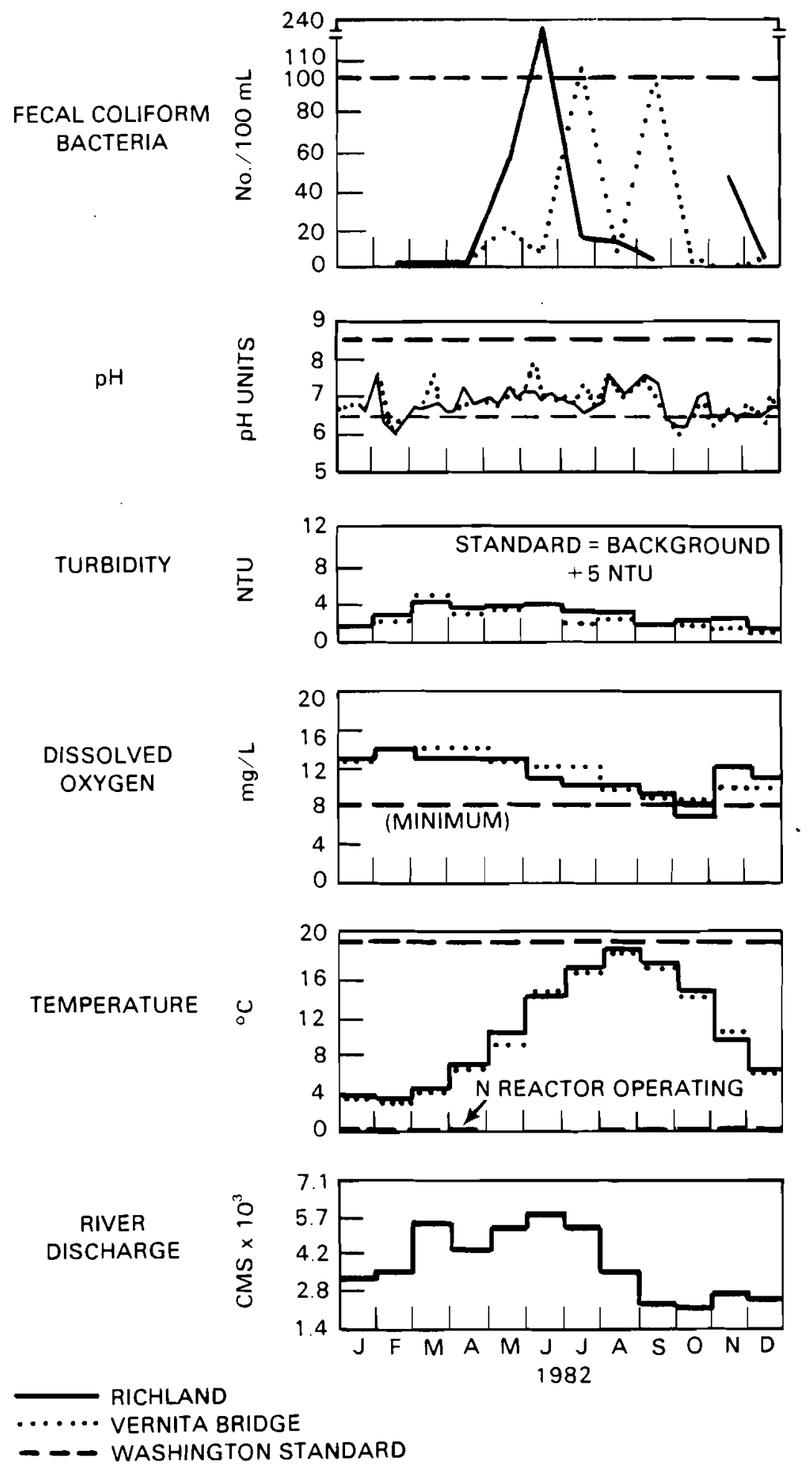

FIGURE 2.4. Results of Monitoring the Quality of Columbia River Water at Hanford, 1982 (after Sula et a1. 1982) 
Windblown sediments and erosion contribute fine materials to exposed islands, gravel bars and shorelines in the Hanford Reach. The annual spring spate, now moderated by reservoir storage and controlled release at dams, normally removes fine particulates from areas exposed during the rest of the year. However, the reduction in magnitude of the annual spring runoff during 19711979 has enhanced the development of shoreline and island vegetation. The high runoff of earlier years scoured many gravel and cobblestone areas free of soil and vegetation. The regulated runoff of today has lost much of its scouring action, and successional stages of vegetation are invading formerly littoral areas (Dewaard 1981).

\subsubsection{Water Temperatures}

Columbia River temperatures range from a maximum near $20^{\circ} \mathrm{C}$ in August to a minimum near $2^{\circ} \mathrm{C}$ in late January or February (Figure 2.5). Temperatures have been monitored at Vernita Bridge and Richland, representing the upper and lower boundaries of the Hanford Reach, from 1961 to 1980 (Whelan and Newbi11 1983). Monthly average temperatures at these locations are nearly identical with slight differences related to season (Puget Power 1982).

The unimpounded river at Hanford is warmed about $0.5^{\circ}$ to $0.75^{\circ} \mathrm{C}$ during August and September, primarily by insolation (Sula et al. 1983). Additionally, fluctuations in discharges at Priest Rapids Dam can impart a daily temperature variation of about $1.2^{\circ} \mathrm{C}$ in the spring and summer and $0.6^{\circ} \mathrm{C}$ in fall and winter to water entering the Hanford Reach (Puget Power 1982). Cooling water discharges from the $N$ Reactor and Hanford Generating Plant (HGP) at RKM 611 also raise the water temperature slightly (WPPSS 1978).

Historically, the most significant change in temperature regime of the Columbia River is due to Lake Roosevelt, behind Grand Coulee Dam (RKM 961), and its massive storage capacity of 5.2 million acre feet. Other river-run reservoirs above Hanford, being much smaller, have produced no significant change in annual average water temperature (Jaske and Goebel 1967). Storage and release of water from Lake Roosevelt since 1941 have delayed the timing of peak summer temperatures in downstream sections of the Columbia River. This delay is about 


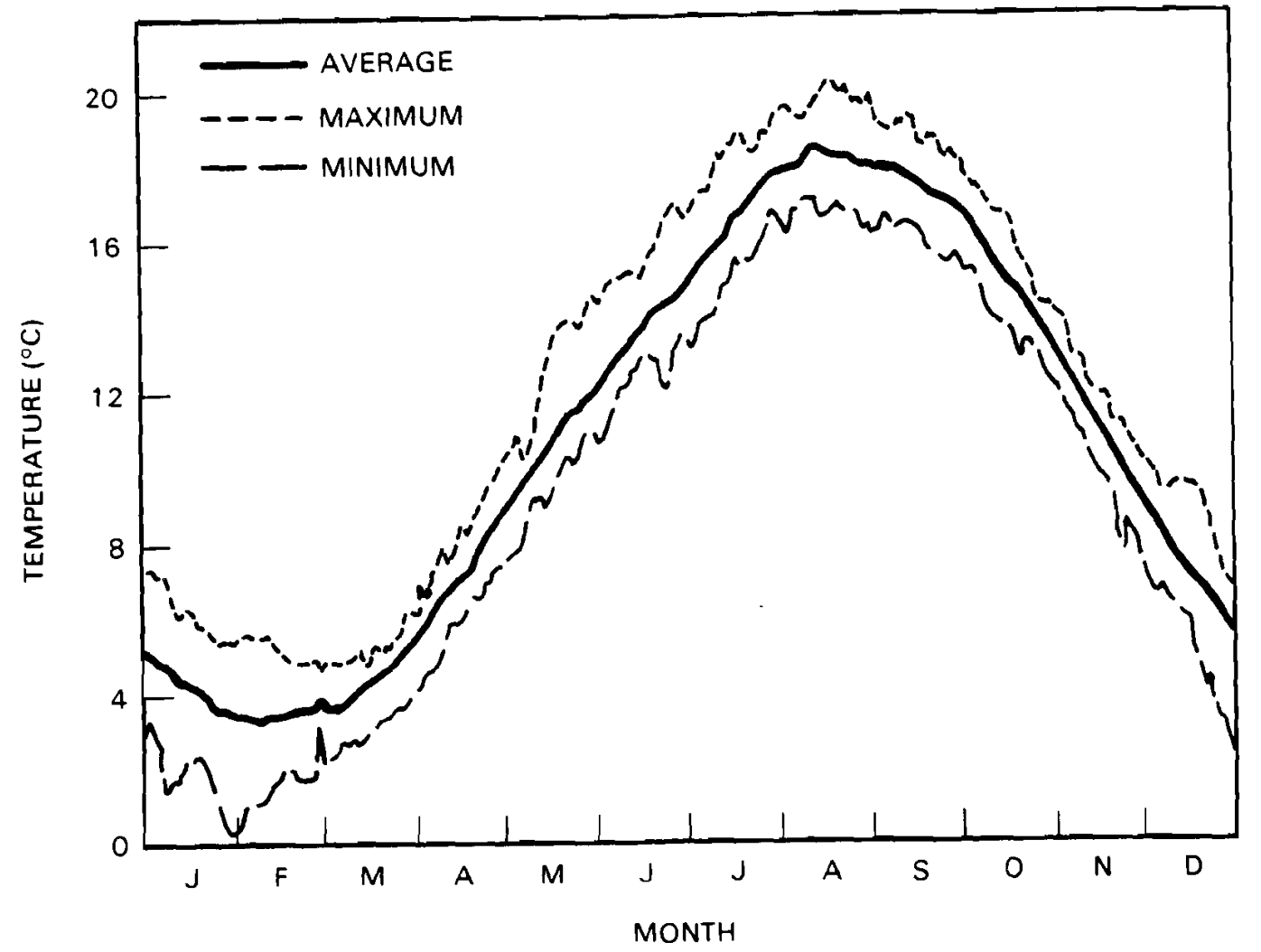

FIGURE 2.5. Mean, Maximum and Minimum Daily Columbia River Water Temperatures at Priest Rapids Dam, 1960-1977 (after U.S. DOE 1982)

30 days at Rock Island Dam (RKM 729) and is reflected, to a lesser extent, as far downstream as Bonneville Dam near the river's outlet (Jaske and Synoground 1970).

Other mainstem reservoirs have little effect on temperature timing because daily discharges are a significant fraction of reservoir capacity (Jaske and Goebel 1967). The reservoir complex tends to moderate high and low temperature extremes. Also, the unimpounded Columbia River responds more rapidly than impounded areas to temperature changes from weather and industrial sources. Therefore, summer warming and winter cooling occur more rapidly in the Hanford Reach (Jaske and Synoground 1970). 


\subsection{SALMONID POPULATIONS}

The anadromous salmonids using the Hanford Reach either for spawning, rearing of young, and downstream and upstream migration are chinook salmon (Oncorhynchus tshawytscha), coho salmon ( $\underline{0}$ kisutch), sockeye salmon (0. nerka), and steelhead (Salmo gairdneri). The largest spawning group at Hanford is the fall chinook salmon run. Anadromous salmonids share the Hanford ecosystem with nearly forty other native and introduced fish species (Gray and Dauble 1977).

Seaward migration of juvenile fish, feeding and growth in the ocean, and return to the river of origin as mature adults are typical of all anadromous salmonids (Figure 3.1). However, the timing of downstream and upstream migration, and the duration of stay in fresh water and the ocean, vary among species.

Because of differences in life cycles, some salmonids are present in the Hanford Reach each month, either as adult upstream migrants or spawners, or as juvenile residents or downstream migrants (smolts) (Figure 3.2). Upstream migration of adult salmonids at Hanford varies seasonally:

$$
\begin{array}{cl}
\begin{array}{c}
\text { Chinook Salmon (a) } \\
\text { spring-run } \\
\text { sunmer-run } \\
\text { fall-run }
\end{array} & \begin{array}{l}
\text { March to mid-June } \\
\text { Mid-August to November }
\end{array} \\
\text { Coho Saimon } & \text { Late August to November } \\
\text { Sockeye Salmon } & \text { July to August } \\
\text { Steelhead } & \begin{array}{l}
\text { August to November maximum, } \\
\text { but present all year. }
\end{array}
\end{array}
$$

(a) Separation of the chinook salmon migration to the Columbia River into spring, summer, and fall runs is a man-induced artifact (Chapman et al. 1982). The original run was represented by a bell-shaped curve from April through September, with a peak generally between June 10 and 20 . The early river fishery severely reduced the main summer run, leaving the spring and fall runs dominant, those runs that received some protection (Thompson 1951; Van Hyning 1973). The early fishery literally took the heart out of the run (Chapman et al. 1982). 


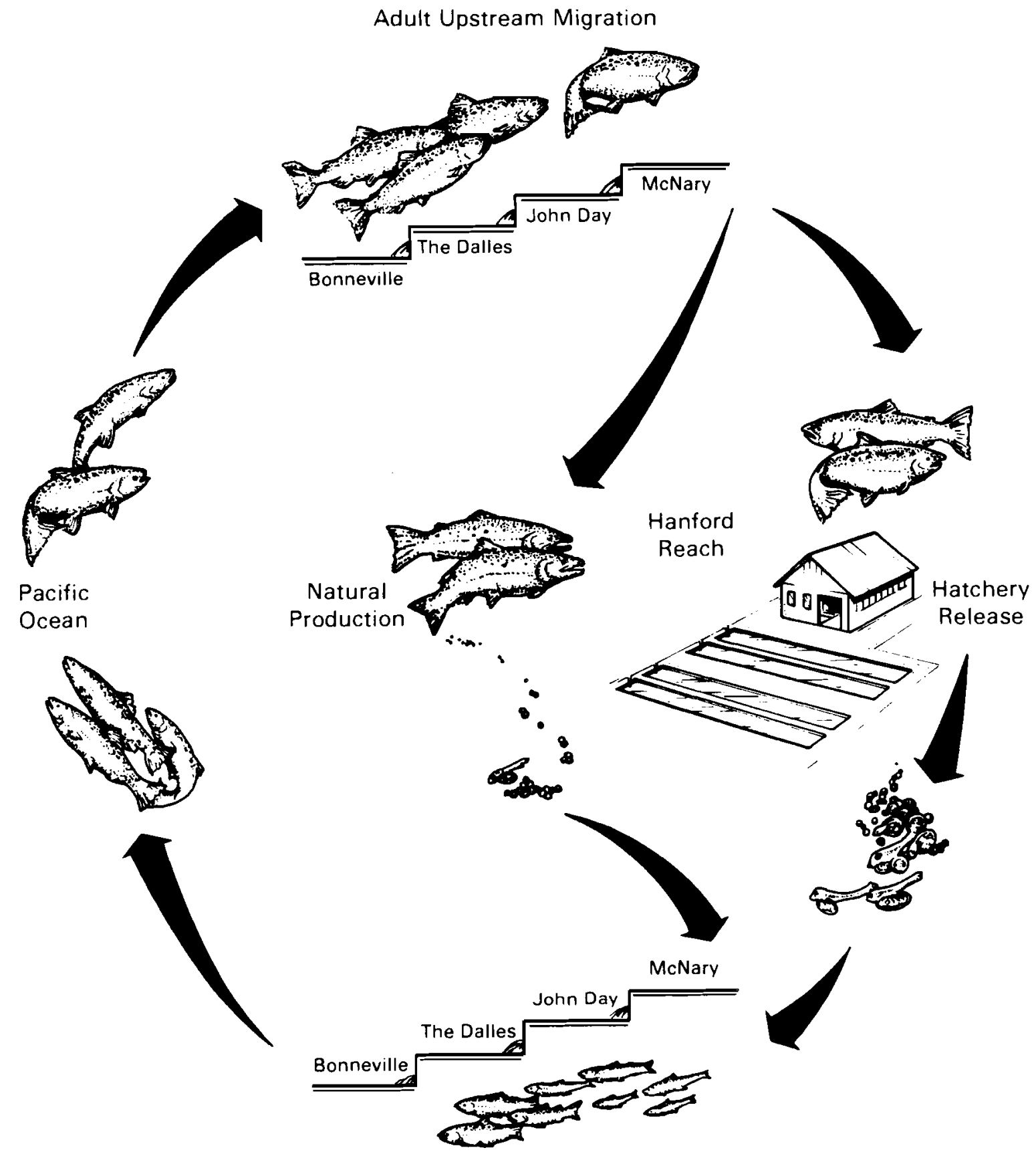

Juvenile Downstream Migration

FIGURE 3.1. Life Cycle of Anadromous Fall Chinook Salmon Associated with the Hanford Reach 


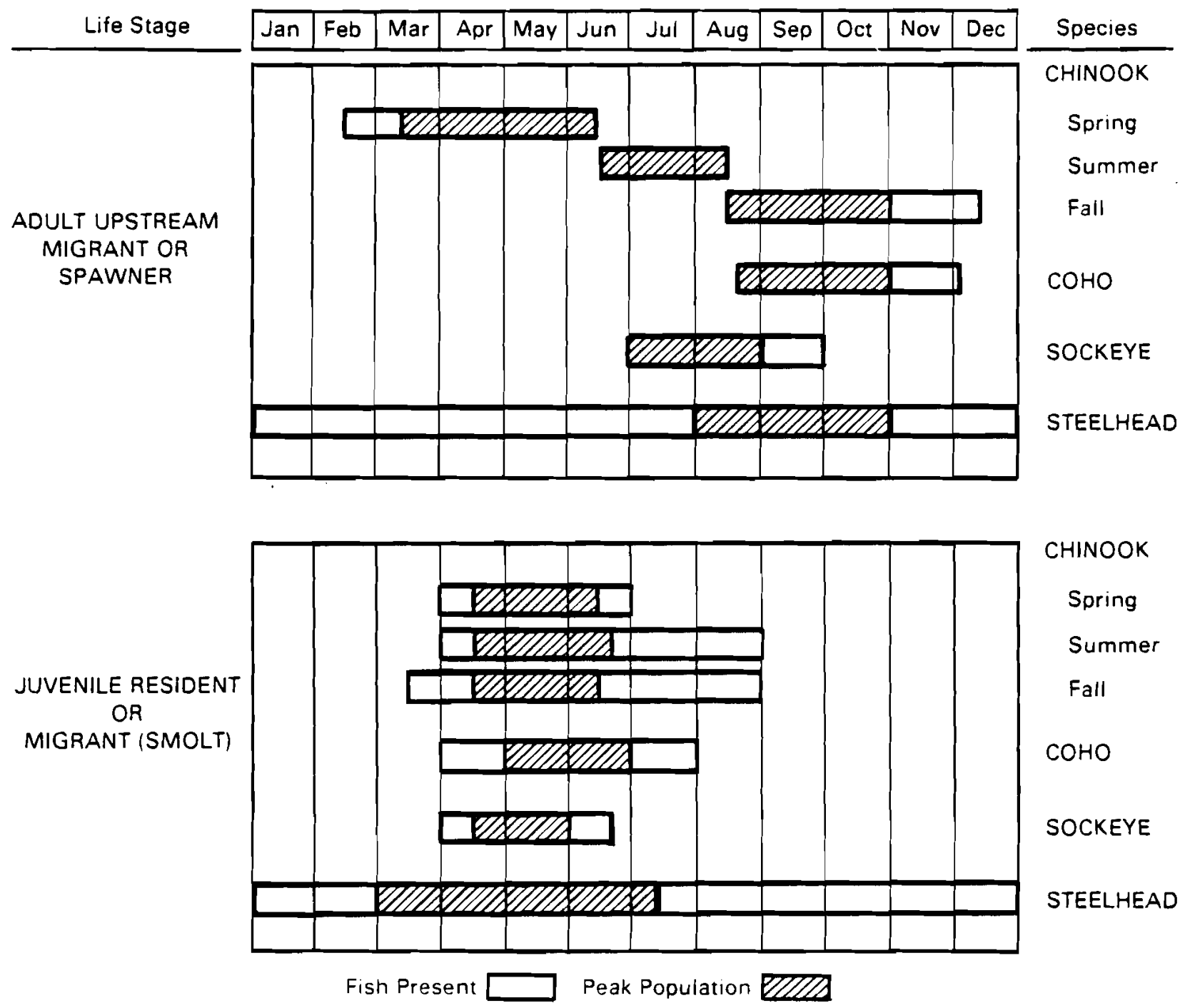

FIGURE 3.2. Seasonal Distribution of Anadromous Salmonids Using the Hanford Reach

The characteristic timing of adult return migrations (ODFW and WDF 1983) and a strong homing instinct (Groves et al. 1968; Banks 1969) allow salmon to be separated into management units called runs. A single species in a large river system may have several distinct runs. In the Columbia River, spring, summer and fall runs of chinook salmon all penetrate $545 \mathrm{kilometers} \mathrm{upstream} \mathrm{to} \mathrm{the}$ Hanford Reach and beyond. Fall chinook salmon associated with Hanford spawn either throughout the Hanford Reach, at Vernita Bar below Priest Rapids Dam, or above Priest Rapids Dam. 
The stocks of fall chinook salmon using the mid-Columbia and Snake rivers today appear to be genetically distinct (Utter et al. 1982). However, there is no clear genetic identity to the fall chinook salmon spawning in the Hanford Reach. According to F. M. Utter (National Marine Fisheries Service, Seattle, Washington), this finding is consistent with recent genetic isolation and/or sufficient gene exchange to prevent establishment of distinct protein coding genes. The lack of clear genetic identity may be attributed to the recent origin of the Hanford stock from fish misplaced by construction of mid-Columbia River dams, the rearing and release of juvenile fish at Priest Rapids Dam, and the release of juvenile fish from other stocks in the Hanford Reach.

The altered habitat represented by reservoirs between the Hanford Reach and the Pacific Ocean may have an effect on upriver populations of salmonids. Each year, substantial numbers of returning adults cannot be accounted for between Bonneville Dam and other dams on the lower Columbia River (Fredd 1966). Reservoirs are instrumental in delayed ocean entry for juvenile outmigrants, but they also provide an alternate type of freshwater rearing habitat. Recent studies (1980 to 1982) indicate that juvenile fall chinook salmon are very abundant in McNary Reservoir below the Hanford Reach after their spring emergence, and that they grow rapidly through June, while using terrestrial insects for the main portion of their diet. While competition for food and space with juvenile resident fish is minimal, predation by smallmouth bass (Micropterus dolomieui) may be substantial in some years (information provided by $W$. $R$. Nelson, USFWS, National Fishery Research Center, Cook, Washington). Whether mainstem reservoirs represent a net plus or minus for outmigrants remains unresolved.

\subsection{CHINOOK SALMON}

This section describes ecological characteristics of chinook salmon runs associated with the Hanford Reach. The following features are discussed: fall-run adults, spring-run and summer-run adults, juvenile production, outmigration and Hanford releases. 


\subsubsection{Fall-Run Adults}

Historically, the main spawning areas for fall chinook salmon were tributaries of the lower Columbia River, the mainstem Columbia River, and the Snake River (Fulton 1968). Fall chinook spawning below Bonneville Dam or in tributaries of the Bonneville pool are called "tules." Those passing above the Bonneville pool and its hatchery system are called "upriver wilds" or "brights" (Horner and Bjornn 1979; ODFW and WDF 1983).

Runs of fall chinook salmon entering the Columbia River today reflect reduced population levels. From 1969 to 1978, runs ascending fishways at Bonneville Dam near the river outlet numbered about 200,000 fish annually. Nearly half of these were harvested by the Indian fishery between Bonneville and MCNary Dams (Fickeisen et al. 1980). Numbers passing MCNary Dam (RKM 470) averaged 71,000 fish from 1968 to 1978, but only 45,000 fish from 1978 to 1983 (Table 3.1). Above McNary Dam, the upriver run of fall chinook salmon diverts to different areas. Some enter the Snake or Yakima rivers, some spawn in the Hanford Reach, and some pass up the Columbia River over Priest Rapids Dam. Numbers of fall chinook entering the Snake River and over Ice Harbor Dam declined from 24,000 to 1,700 fish from 1968 to 1978, and averaged only 2,200 fish (range 1,600 to 3,500) from 1978 to 1983 (Table 3.1). The number passing over Priest Rapids Dam ranged between 5,400 and 16,000 from 1968 to 1982 (Tables 3.1 and 3.2). The number spawning in the mid-Columbia area (e.g., between McNary, Ice Harbor and Priest Rapids dams) is usually 25,000 to 70,000 fish.

Fall chinook salmon pass through the Hanford Reach to limited spawning areas above Priest Rapids Dam from the middle of August to November. Some spawning occurs in the tailraces of Rocky Reach and Wanapum dams (Horner and Bjornn 1979). However, the largest segment of the upriver run spawns in the Hanford area from October through November, peaking in late October and early November (Watson 1976; Chapman et al. 1983).

Adult salmonids characteristically travel parallel to the banks during upstream migrations in large rivers. In the Hanford Reach, adult chinook salmon usually migrate close to the north or east bank (Franklin County side) (Becker 1973a; Coutant 1973). The migration path is not consistent. Fish may 
TABLE 3.1. Annual Estimates of Adult (a) Fall Chinook Salmon in the Mid-Columbia River Since 1960

\begin{tabular}{|c|c|c|c|c|c|}
\hline \multirow[b]{2}{*}{ Year } & \multicolumn{3}{|c|}{ Dam Count } & \multirow{2}{*}{$\begin{array}{c}\text { Yakima } \\
\text { River } \\
\text { Escapement } \\
\end{array}$} & \multirow{2}{*}{$\begin{array}{l}\text { Interdam } \\
\text { Population } \\
\text { (estimate) }\end{array}$} \\
\hline & McNary & Ice Harbor & Priest Rapids & & \\
\hline $\begin{array}{l}1960 \\
1961 \\
1962 \\
1963 \\
1964\end{array}$ & $\begin{array}{l}47,337 \\
41,200 \\
44,116 \\
57,363 \\
58,593\end{array}$ & $\begin{array}{r}30,049 \\
13,537 \\
11,09\end{array}$ & $\begin{array}{l}10,687 \\
11,108 \\
10,082 \\
17,563 \\
14,760\end{array}$ & $\begin{array}{r}87 \\
15 \\
324 \\
120\end{array}$ & $\begin{array}{r}3,970 \\
25,936 \\
32,616\end{array}$ \\
\hline $\begin{array}{l}1965 \\
1966 \\
1967 \\
1968 \\
1969\end{array}$ & $\begin{array}{l}76,326 \\
75,119 \\
73,087 \\
72,757 \\
79,375\end{array}$ & $\begin{array}{l}12,354 \\
15,018 \\
19,022 \\
24,377 \\
17,507\end{array}$ & $\begin{array}{l}21,149 \\
18,821 \\
12,375 \\
11,031 \\
12,367\end{array}$ & $\begin{array}{r}198 \\
405 \\
531 \\
186 \\
2,487\end{array}$ & $\begin{array}{l}42,625 \\
40,875 \\
41,159 \\
37,163 \\
47,014\end{array}$ \\
\hline $\begin{array}{l}1970 \\
1971 \\
1972 \\
1973 \\
1974\end{array}$ & $\begin{array}{l}61,554 \\
69,718 \\
49,307 \\
73,253 \\
62,009\end{array}$ & $\begin{array}{r}10,385 \\
11,004 \\
9,436 \\
8,353 \\
2,814\end{array}$ & $\begin{array}{r}16,372 \\
10,591 \\
5,782 \\
10,083 \\
7,618\end{array}$ & $\begin{array}{l}1,830 \\
2,090 \\
1,480 \\
2,200 \\
1,860\end{array}$ & $\begin{array}{l}32,967 \\
46,033 \\
32,611 \\
52,617 \\
49,717\end{array}$ \\
\hline $\begin{array}{l}1975 \\
1976 \\
1977 \\
1978 \\
1979 \\
1980 \\
1981 \\
1982 \\
1983 \\
1984\end{array}$ & $\begin{array}{r}68,719 \\
87,991 \\
84,370 \\
44,145 \\
49,961 \\
38,910 \\
33,148 \\
57,299 \\
73,801 \\
110,275\end{array}$ & $\begin{array}{l}2,558 \\
1,474 \\
1,756 \\
1,609 \\
2,074 \\
1,744 \\
2,111 \\
3,519 \\
2,735 \\
2,445\end{array}$ & $\begin{array}{r}13,365 \\
10,774 \\
6,856 \\
6,523 \\
7,727 \\
8,441 \\
5,438 \\
13,110 \\
10,668 \\
12,695\end{array}$ & $\begin{array}{l}2,060 \\
2,640 \\
2,531 \\
1,324 \\
1,499 \\
1,167\end{array}$ & $\begin{array}{l}50,736 \\
73,103 \\
73,227 \\
34,689 \\
38,661 \\
27,557\end{array}$ \\
\hline
\end{tabular}

(a) Data are total counts, and include precocious male "jacks."

Sources: Dam counts from U.S. ACOE 1983 (MCNary and Ice Harbor), and Grant County Public Utility District No. 2 (Priest Rapids); see Table 3.2. Yakima River escapement from Watson, 1970; other data supplied by D. G. Watson, Pacific Northwest Laboratory. 
TABLE 3.2. Counts of Adult Salmonids at the Fishway of Priest Rapids Dam

\begin{tabular}{|c|c|c|c|c|c|c|c|}
\hline Year & $\begin{array}{c}\text { Fall } \\
\text { Chinook (a) } \\
\end{array}$ & $\begin{array}{c}\text { Spring } \\
\text { Chinook (a) }\end{array}$ & $\begin{array}{c}\text { Summer } \\
\text { Chinook (a) }\end{array}$ & Coho (a) & Sockeye & Steelhead & $\begin{array}{c}\text { Total } \\
\text { Salmonids } \\
\end{array}$ \\
\hline $\begin{array}{l}1960 \\
1961 \\
1962 \\
1963 \\
1964\end{array}$ & $\begin{array}{l}10,687 \\
11,108 \\
10,082 \\
17,563 \\
14,760\end{array}$ & $\begin{array}{l}8,534 \\
8,385 \\
7,993 \\
7,597 \\
9,814\end{array}$ & $\begin{array}{l}20,852 \\
18,245 \\
20,824 \\
18,511 \\
26,489\end{array}$ & $\begin{array}{r}58 \\
88 \\
601 \\
29 \\
60\end{array}$ & $\begin{array}{l}58,201 \\
19,793 \\
28,575 \\
64,883 \\
79,072\end{array}$ & $\begin{array}{l}7,827 \\
8,559 \\
9,324 \\
9,344 \\
6,009\end{array}$ & $\begin{array}{r}106,159 \\
66,178 \\
77,399 \\
177,927 \\
136,204\end{array}$ \\
\hline $\begin{array}{l}1965 \\
1966 \\
1967 \\
1968 \\
1969\end{array}$ & $\begin{array}{l}21,149 \\
18,821 \\
12,375 \\
11,031 \\
12,367\end{array}$ & $\begin{array}{r}5,718 \\
13,358 \\
10,307 \\
10,739 \\
7,142\end{array}$ & $\begin{array}{l}24,936 \\
29,736 \\
26,256 \\
26,544 \\
21,277\end{array}$ & $\begin{array}{r}448 \\
11,903 \\
8,879 \\
13,212 \\
1,351\end{array}$ & $\begin{array}{r}48,340 \\
170,071 \\
123,786 \\
108,308 \\
39,240\end{array}$ & $\begin{array}{r}9,041 \\
13,006 \\
7,354 \\
10,524 \\
6,650\end{array}$ & $\begin{array}{r}109,632 \\
256,896 \\
188,957 \\
180,358 \\
88,027\end{array}$ \\
\hline $\begin{array}{l}1970 \\
1971 \\
1972 \\
1973 \\
1974\end{array}$ & $\begin{array}{r}16,372 \\
10,591 \\
5,782 \\
10,083 \\
7,618\end{array}$ & $\begin{array}{r}5,789 \\
5,086 \\
8,775 \\
9,967 \\
11,127\end{array}$ & $\begin{array}{l}21,641 \\
20,481 \\
18,083 \\
14,351 \\
13,703\end{array}$ & $\begin{array}{l}4,971 \\
7,738 \\
5,225 \\
1,576 \\
1,781\end{array}$ & $\begin{array}{l}77,419 \\
73,837 \\
44,927 \\
54,480 \\
35,434\end{array}$ & $\begin{array}{r}5,558 \\
11,102 \\
6,429 \\
6,999 \\
3,089\end{array}$ & $\begin{array}{r}131,750 \\
128,835 \\
89,221 \\
97,456 \\
72,752\end{array}$ \\
\hline $\begin{array}{l}1975 \\
1976 \\
1977 \\
1978 \\
1979\end{array}$ & $\begin{array}{r}13,365 \\
10,774 \\
6,856 \\
6,523 \\
7,727\end{array}$ & $\begin{array}{r}8,170 \\
13,306 \\
21,217 \\
21,427 \\
7,750\end{array}$ & $\begin{array}{l}22,205 \\
19,344 \\
19,605 \\
22,580 \\
22,689\end{array}$ & $\begin{array}{r}2,193 \\
2,275 \\
370 \\
597 \\
311\end{array}$ & $\begin{array}{l}55,210 \\
32,810 \\
95,413 \\
17,529 \\
45,662\end{array}$ & $\begin{array}{l}2,462 \\
9,248 \\
9,803 \\
4,545 \\
8,409\end{array}$ & $\begin{array}{r}103,605 \\
87,757 \\
153,264 \\
73,201 \\
92,548\end{array}$ \\
\hline $\begin{array}{l}1980 \\
1981 \\
1982 \\
1983 \\
1984\end{array}$ & $\begin{array}{r}8,441 \\
5,438 \\
13,110 \\
10,668 \\
12,695\end{array}$ & $\begin{array}{r}11,136 \\
14,787 \\
9,088 \\
10,780 \\
12,662\end{array}$ & $\begin{array}{r}18,708 \\
12,381 \\
9,883 \\
9,573 \\
17,372\end{array}$ & $\begin{array}{r}318 \\
428 \\
1,810 \\
502 \\
172\end{array}$ & $\begin{array}{r}52,039 \\
51,461 \\
40,461 \\
90,008 \\
114,766\end{array}$ & $\begin{array}{r}8,524 \\
9,117 \\
11,119 \\
31,882 \\
26,209\end{array}$ & $\begin{array}{r}99,166 \\
93,612 \\
85,471 \\
153,413 \\
183,876\end{array}$ \\
\hline
\end{tabular}

(a) Chinook and coho salmon data include precocious male "jacks."

Sources: After 01 son 1981; recent data supplied by M. B. Dell, Grant County Public Utility District No. 2, Ephrata, Washington.

cross from one bank to another near obstructions or in high turbulence areas along the shoreline, which become prominent during low flow periods.

The numbers of fall chinook that spawn in the Hanford Reach increased markedly after 1960, following the construction of Priest Rapids Dam. The initial increase was probably due to the barrier created by the dam and to the upstream translocation of fish whose spawning grounds were inundated by dams 
below Hanford (Watson 1970). Subsequent levels of spawners were influenced, to an undetermined extent, by smolts reared artificially and released below Priest Rapids Dam.

Annual surveys of fall chinook salmon redds have been made at Hanford since 1947 (Figure 3.3). The number of redds increased dramatically from about 300 in 1960 to 4,500 in 1969. A general decline occurred from 1970 to 1980 , but the number of redds then increased to peak at 7,310 in 1984. Redd counts are limited for estimating the total number of spawners in any given year. Their main value is in establishing long-term trends that show stability, increases or decreases in the annual number of spawners. Post-dam counts of

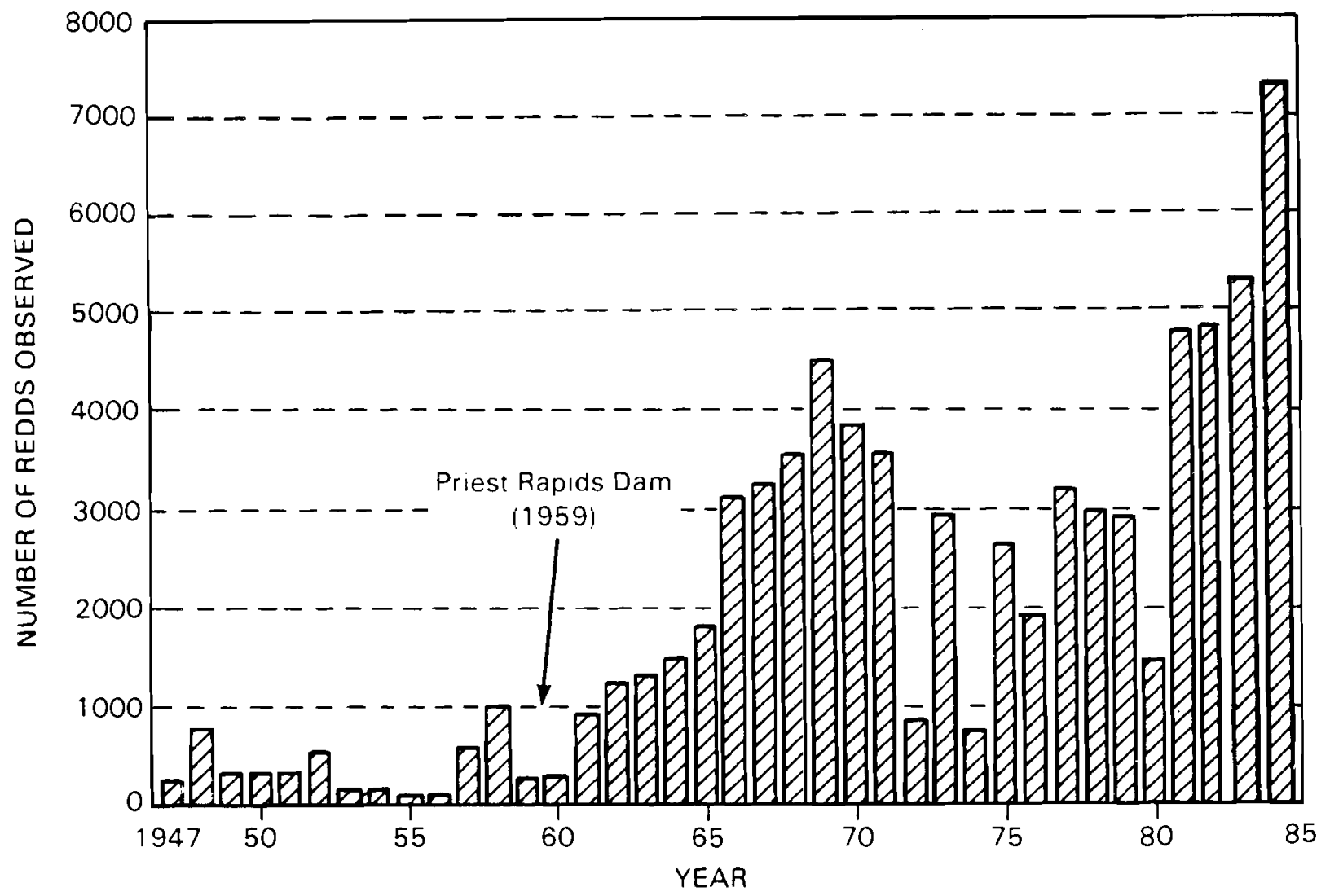

FIGURE 3.3. Relative Abundance of Fall Chinook Salmon Redds in the Hanford Reach, 1947 through 1981 (after Watson 1970, 1976; recent data supplied by $\mathrm{n}$. F. Watson, Pacific Northwest Laboratory) 
spawning fall chinook at Vernita Bar show a twelvefold increase over pre-dam counts, and about a fivefold increase for the Hanford Reach (Chapman et al. 1983).

Redd counts from aircraft over large rivers are affected by stream discharge and any other condition that alters visibility. Counts made at low discharges, where more redds are visible, are usually higher than counts made at high discharges. Vernita Bar counts since 1975 at flows above 36,000 cubic feet per second reveal an average of only $34 \%$ (range $12.8 \%$ to $51.4 \%$ ) of the redds counted at flows near 36,000 cubic feet per second (Chapman et al. 1983).

A

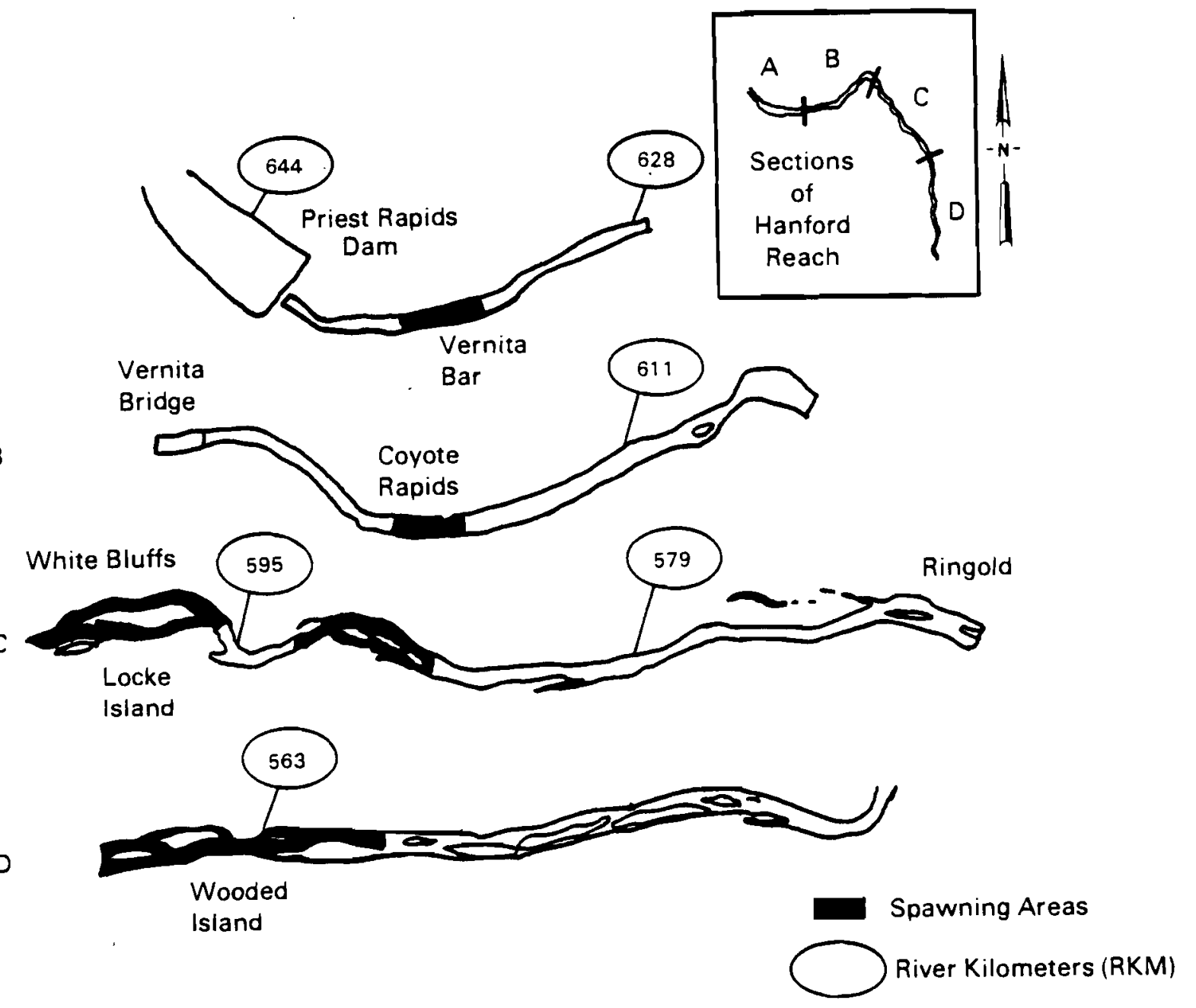

FIGIJRE 3.4. Major Spawning Areas Ilsed by Fall Chinook Salmon in the Hanford Reach (after Watson 1976) 
Even at low flows, a number of redds are always deposited each year at depths below the limit of detection from the surface or above.

Several areas at Hanford are used by fall chinook salmon to spawn (Figure 3.4). Redds are counted annually in defined spawning areas. Since 1967 , most spawning has occurred at Vernita Rar (36\% average contribution), which lies below Priest Rapids Dam, and at RKM 600-605 above White Bluffs (35\% average contribution) (Table 3.3).

Conceivably, some areas suitable for spawning in the Hanford Reach are not used because sexually mature adults tend to concentrate upstream in the vicinity of Vernita Rar. If use of other areas could be enhanced, a larger spawning population of fall chinook might be accommodated. Present concentrations of spawners near Vernita Bar may lead to some superimposition of redds. Such superimposition may result, not from too many spawners at any one time, but rather from the long spawning season. Redds constructed early become vulnerable to overlap later when the females that arrive first die and can no longer defend their redds (Chapman et al. 1983). Females spawning in late nctober are unlikely to survive to mid-November, the late part of the spawning season, making early redds vulnerable.

Spawning of fall chinook salmon at Vernita Bar usually begins during the second half of October, although fish appear at the site earlier. Inder ambient river temperature conditions, about $50 \%$ of the eggs deposited in redds at Vernita Bar hatch during the first half of December (Chapman et a1. 1983). While fry emerge from the gravel primarily in April and May (Chapman et al. 1983), emergence may begin as early as March. The general timing of spawning, hatching, and emergence is probably similar throughout the Hanford Reach. Peak numbers of 0 -age fry usually occur in shoreline areas at Hanford from April through May (Mains and Smith 1964; Gray and Page 1979a, 1979b).

Reduced flows can force spawning fish from redds started at higher flows. However, redds dug by fall chinook salmon at Vernita Bar can be completed in less than 24 hours and, with a diel cycle of water level fluctuations, fish displaced at low flow can complete a redd during the next.high-flow period 
TABLE 3.3. Distribution of Fall Chinook Salmon Redds in the Hanford Reach by Major Spawning Area

Number of Redds by Spawning Area

\begin{tabular}{|c|c|c|c|c|c|c|c|c|}
\hline Year & $\begin{array}{c}\text { RKM } 570 \\
\text { (Ringold) } \\
\end{array}$ & $\begin{array}{c}\text { RKM } 587 \\
\text { to } \\
592 \\
\end{array}$ & $\begin{array}{l}\text { RKM } 597 \\
\text { (White } \\
\text { Bluffs) } \\
\end{array}$ & $\begin{array}{c}\text { RKM } 600 \\
\text { to } \\
605 \\
\end{array}$ & $\begin{array}{l}\text { RKM 616 } \\
\text { (Coyote } \\
\text { Rapids) } \\
\end{array}$ & $\begin{array}{r}\text { RKM } 632 \\
\text { (Midway) } \\
\end{array}$ & $\begin{array}{l}\text { Other } \\
\text { Redds } \\
\end{array}$ & $\begin{array}{l}\text { Total } \\
\text { Redds } \\
\end{array}$ \\
\hline $\begin{array}{l}1947 \\
1948 \\
1949 \\
1950 \\
1951 \\
1952 \\
1953 \\
1954\end{array}$ & $\begin{array}{r}0 \\
120 \\
45 \\
24 \\
5 \\
73 \\
7 \\
4\end{array}$ & $\begin{array}{r}15 \\
330 \\
50 \\
43 \\
10 \\
101 \\
5 \\
5\end{array}$ & $\begin{array}{r}25 \\
38 \\
6 \\
38 \\
45 \\
40 \\
16 \\
8\end{array}$ & $\begin{array}{r}10 \\
219 \\
195 \\
151 \\
151 \\
221 \\
38 \\
127\end{array}$ & $\begin{array}{l}0 \\
0 \\
0 \\
3 \\
5 \\
3 \\
0 \\
0\end{array}$ & $\begin{array}{r}75 \\
25 \\
1 \\
46 \\
95 \\
78 \\
83 \\
6\end{array}$ & $\begin{array}{r}115 \\
53 \\
33 \\
11 \\
3 \\
23 \\
0 \\
7\end{array}$ & $\begin{array}{l}240 \\
785 \\
330 \\
316 \\
314 \\
539 \\
149 \\
157\end{array}$ \\
\hline $\begin{array}{l}1955 \\
1956(a) \\
1957(a) \\
1958(a) \\
1959 \\
1960 \\
1961 \\
1962 \\
1963 \\
1964\end{array}$ & $\begin{array}{r}0 \\
0 \\
17 \\
32 \\
1 \\
0 \\
0 \\
6 \\
0 \\
5\end{array}$ & $\begin{array}{r}12 \\
3 \\
88 \\
105 \\
0 \\
31 \\
27 \\
195 \\
283 \\
163\end{array}$ & $\begin{array}{r}0 \\
7 \\
39 \\
99 \\
36 \\
22 \\
43 \\
66 \\
127 \\
111\end{array}$ & $\begin{array}{r}47 \\
59 \\
290 \\
332 \\
101 \\
99 \\
201 \\
456 \\
506 \\
510\end{array}$ & $\begin{array}{r}0 \\
0 \\
42 \\
130 \\
32 \\
38 \\
23 \\
1 \\
14 \\
37\end{array}$ & $\begin{array}{r}4 \\
17 \\
100 \\
176 \\
111 \\
105 \\
640 \\
535 \\
370 \\
624\end{array}$ & $\begin{array}{r}1 \\
6 \\
1 \\
48 \\
0 \\
0 \\
4 \\
2 \\
3 \\
27\end{array}$ & $\begin{array}{r}64 \\
92 \\
577 \\
922 \\
281 \\
295 \\
939 \\
1,261 \\
1,303 \\
1,477\end{array}$ \\
\hline $\begin{array}{l}1965 \\
1966 \\
1967 \\
1968 \\
1969 \\
1970 \\
1971 \\
1972 \\
1973 \\
1974\end{array}$ & $\begin{array}{r}4 \\
10 \\
28 \\
117 \\
265 \\
107 \\
182 \\
88 \\
137 \\
104\end{array}$ & $\begin{array}{l}262 \\
279 \\
388 \\
595 \\
820 \\
615 \\
560 \\
247 \\
458 \\
156\end{array}$ & $\begin{array}{r}211 \\
267 \\
273 \\
188 \\
427 \\
302 \\
416 \\
147 \\
179 \\
49\end{array}$ & $\begin{array}{r}588 \\
1,206 \\
1,192 \\
1,069 \\
1,446 \\
1,180 \\
1,071 \\
259 \\
1,273 \\
238\end{array}$ & $\begin{array}{r}54 \\
37 \\
17 \\
52 \\
50 \\
72 \\
10 \\
4 \\
62 \\
5\end{array}$ & $\begin{array}{r}659 \\
1,300 \\
1,340 \\
1,520 \\
1,500 \\
1,528 \\
1,361 \\
131 \\
856 \\
173\end{array}$ & $\begin{array}{r}11 \\
2 \\
29 \\
39 \\
0 \\
9 \\
0 \\
0 \\
0 \\
3\end{array}$ & $\begin{array}{r}1,789 \\
3,101 \\
3,269 \\
3,595 \\
4,508 \\
3,813 \\
3,600 \\
876 \\
2,965 \\
728\end{array}$ \\
\hline $\begin{array}{l}1975 \\
1976 \\
1977 \\
1978 \\
1979 \\
1980 \\
1981 \\
1982 \\
1983 \\
1984\end{array}$ & $\begin{array}{r}95 \\
25 \\
15 \\
18 \\
67 \\
30 \\
82 \\
9 \\
24 \\
62\end{array}$ & $\begin{array}{l}458 \\
313 \\
473 \\
216 \\
396 \\
157 \\
421 \\
368 \\
444 \\
712\end{array}$ & $\begin{array}{r}291 \\
185 \\
355 \\
326 \\
297 \\
64 \\
275 \\
290 \\
511 \\
1,100\end{array}$ & $\begin{array}{r}752 \\
647 \\
1,577 \\
1,389 \\
1,151 \\
346 \\
1,875 \\
1,978 \\
1,994 \\
3,034\end{array}$ & $\begin{array}{r}91 \\
182 \\
48 \\
80 \\
92 \\
35 \\
80 \\
168 \\
43 \\
58\end{array}$ & $\begin{array}{r}995 \\
599 \\
772 \\
999 \\
980 \\
855 \\
2,132 \\
2,159 \\
2,216 \\
2,337\end{array}$ & $\begin{array}{r}1 \\
0 \\
0 \\
0 \\
0 \\
0 \\
0 \\
16 \\
0 \\
7\end{array}$ & $\begin{array}{l}2,683 \\
1,951 \\
3,240 \\
3,028 \\
2,983 \\
1,487 \\
4,866 \\
4,988 \\
5,290 \\
7,310\end{array}$ \\
\hline
\end{tabular}

(a) 1957 and 1958 counts are corrected values. The original published values were the sum of all redds observed, $i . e .$, the sum of all survey counts from fixed-wing aircraft.

Sources: After Watson 1970, 1976; recent data supplied by D.G. Watson, Pacific Northwest Laboratory. 
(Chapman et al. 1983). In the Skagit River, Washington, marked female chinook commonly return to the same redd after displacement by temporary low flows (Stober et al. 1982).

Egg retention in carcasses of female salmon may reveal adverse conditions that limit spawning success. Egg retention by spawned-out females near and below Vernita Bar is apparently low, with less than $2 \%$ retaining over 400 eggs (Chapman et a1. 1983). This indicates that water level changes from power peaking at Priest Rapids Dam do not cause significant spawning failure in the Hanford Reach. However, water level fluctuations do reduce the available spawning area, and the possibility exists that intergravel survival of embryos and emergence of alevins might be impaired.

\subsubsection{Spring-Run and Summer-Run Adu1ts}

Historically, spring chinook salmon consist of an early run destined for the lower Columbia River and a later run destined for the middle and upper Columbia and Snake rivers. However, nearly all summer chinook head for the upper Columbia River (Fulton 1968; Horner and Bjornn 1981b; ODFW and WDF 1983).

Adult spring chinook pass through the Hanford Reach from April through mid-June, and usually spawn in smaller tributaries and upper reaches of principal tributaries between August and early September (Fulton 1968; Horner and Bjornn 1981b). Summer-run fish pass through Hanford from mid-June to midAugust, and usually spawn in large- to medium-sized tributaries and some mainstem areas of the Columbia River from late September to early November (Fulton 1968; Horner and Bjornn 1981c).

Today, runs of spring chinook salmon above McNary Dam are depressed. Prior to construction of most mainstem Columbia River dams (1945 to 1960), the average upriver run was about $23,000 \mathrm{fish}$. However, the annual average has dropped to about 10,200 fish (range 5,100 to $21,400 \mathrm{fish}$ ) at Priest Rapids Dam since 1960 (Horner and Bjornn 1981b). From 1962 to 1980, those spring chinook passing Priest Rapids Dam averaged $26 \%$ (range $11 \%$ to $46 \%$ ) of the combined upper-Columbia and Snake river runs.

Runs of suminer chinook salmon are the most severely depressed of all salmon runs to the Columbia River (ODFW and WDF 1983). Minimum escapement goals 
at Bonneville Dam have not been reached since 1969. Prior to construction of most mainstem Columbia River dams (1945 to 1960), the average upriver run was about 33,600 fish. Since 1960, however, the run has dropped to about 21,300 fish annually (range 13,700 to 29,700 ) at Priest Rapids Dam (Horner and Bjornn 1981c). From 1970 to 1980, those summer chinook passing Priest Rapids Dam averaged $58 \%$ of the combined upper-Columbia and Snake river runs.

The annual sizes of spring and summer chinook runs counted at Priest Rapids Dam from 1960 to 1982 are included in Table 3.2. All juvenile fish originating above Priest Rapids Dam, including hatchery releases, subsequently pass through Hanford on their way to the sea.

\subsubsection{Juvenile Production}

Generally, juvenile fall chinook salmon originating from natural spawning above and in the Hanford Reach migrate seaward in their first year of life (0-age group) (Major and Mighell 1969; Rell 1973). Juvenile surmmer chinook originating above Hanford also migrate in their first year (Horner and Bjornn 1981c), while most juvenile spring chinook migrate as smolts in their second year (1-age group) (Horner and Bjornn 1981b).

The Hanford contribution of juvenile salmonids consists of two main segments: those fish produced from natural spawning in the Hanford Reach and those fish produced from natural spawning and hatchery releases above Hanford. In addition, some hatchery-reared fish are released in the Hanford Reach. There are no accepted estimates of the number of juvenile fall chinook produced by the naturally spawning population in the Hanford Reach.

Chinook salmon smolts passing seaward through the Hanford Reach from above McNary Dam are mixtures of hatchery and wild fish. Thus, outmigration size varies with relative success of natural production and number of hatchery releases. These factors change from year to year.

Few fall chinook have been released over the years at the Leavenworth Hatchery complex (Leavenworth, Entiat and Winthrop National Fish Hatcheries). Current production by the federal hatcheries is almost entirely of spring chinook salmon, according to a plan developed by the interagency crand Coulee Fish Rehabilitation Committee in the 1970's (Mullan 1982). 
About three million (average) spring chinook salmon smolts were released annually from the Federal hatcheries from 1976 to 1979 (Horner and Bjornn 1981b). Total artificial production was scheduled to reach about six million smolts annually in 1981. However, the gene pool of upriver spring chinook stocks has been altered by rearing of eggs taken from the lower and middle Columbia River. Today, the Wenatchee, Entiat and Methow river drainages are the only tributaries above Priest Rapids Dam that still support natural runs of spring chinook salmon (Horner and Bjornn 1981b).

An average of 2.2 million (range 844,800 to $3,824,300$ ) summer chinook smolts were released annually at the Wells Hatchery (RKM 830) between 1968 and 1979 (Horner and Bjornn 1981C). Total artificial production (hatchery plus spawning channels) in the upper Columbia River was scheduled to be about 4.3 million smolts annually by 1980. Today, the Wenatchee, Methow, Similkamean and Okanogan river drainages produce most of the natural runs of summer chinook above Priest Rapids Dam (Horner and Bjornn 1981C).

\subsubsection{Outmigration}

The smolt outmigration in the Columbia River system now occurs up to 2 weeks later than it did before extensive dam construction. Impoundments represent areas of reduced currents; therefore, they tend to delay the seaward migration (Raymond 1968, 1969; Park 1969). Juvenile chinook salmon move about one third as fast through impounded sections of the river as through flowing sections. The delay has ecological implications. A normal, unrestrained outmigration is timed by nature to correspond with physiological changes (smoltification) that lead to development of seawater tolerance (Wedemeyer et al. 1980). Delay may impair the ability of smolts to adapt from fresh to salt water (Mahnken et a1. 1982).

In recent year's, the smolt outmigration from above Hanford has been sampled by gatewell collections at Priest Rapids Dam. However, gatewell collections provide only general estimates of annual outmigration numbers. Since the portion of smolts using the spillways varies with discharge, and spillway discharges vary seasonally and from year to year, there is room for considerable error. Gatewell sampling does identify peak outmigration periods and provides useful comparison of relative smolt abundance among species (Table 3.4). 
TABLE 3.4. Peak Dutmigration Dates(a) for Juvenile Salmonids at Priest Rapids Dam, and Their Percent Relative Abundance for Years Where Data Are Comparable

Fall and

$$
\begin{gathered}
\text { Summer } \\
\text { Chinook }
\end{gathered}
$$

\begin{tabular}{|c|c|c|c|c|c|}
\hline Year & (0-Age Group) & (1-Age Group) & Coho & Sockeye & Steelhead \\
\hline 1965 & Aug 11 & May 19 & May 12 & May 3 & May 20 \\
\hline 1966 & Aug 12 & May 17 & April 29 & May 1 & May 25 \\
\hline 1967 & Aug 8 & May 23 & May 20 & May 1 & May 18 \\
\hline 1976 & Aug 11 & May $14(41 \%)$ & May $19(16 \%)$ & May $19(34 \%)$ & May $14(9 \%)$ \\
\hline 1977 & $\mathrm{ND}^{(\mathrm{c})}$ & May $17(53 \%)$ & May $25(9 \%)$ & May $14(31 \%)$ & May $17(7 \%)$ \\
\hline 1979 & ND & May $19(28 \%)$ & May $23(17 \%)$ & May $21(48 \%)$ & May $18(7 \%)$ \\
\hline 1980 & ND & May $12(56 \%)$ & May $25(11 \%)$ & May $14(20 \%)$ & May $10(13 \%)$ \\
\hline 1981 & Aug 12 & May 15 (50\%) & May $21(4 \%)$ & May $14(40 \%)$ & May $15(6 \%)$ \\
\hline 1982 & JuT 29 & May 7 (64\%) & May $19(1 \%)$ & May $18(28 \%)$ & May $11(7 \%)$ \\
\hline 1983 & Ju1 26 & May $9(39 \%)$ & May 14 (10) & May $5(41 \%)$ & May $9(9 \%)$ \\
\hline 1984 & Aug 13 & May $12(41 \%)$ & May $23(15 \%)$ & May $12(22 \%)$ & May $15(22 \%)$ \\
\hline $\begin{array}{l}\text { Range } \\
\text { of } \\
\text { peak }\end{array}$ & $\begin{array}{l}\text { JuT } 26- \\
\text { Aug } 13\end{array}$ & May $7-23$ & $\begin{array}{l}\text { Apr } 29- \\
\text { May } 25\end{array}$ & May 1-21 & May $9-25$ \\
\hline
\end{tabular}

(a) Peak migration date is the day when $50 \%$ of the total number of juveniles that season were captured.

(b) Relative abundance of chinook salmon (in parentheses) is the combined runs (fall, summer and spring).

(c) $N D=$ No Data; total number of outmigrants could not be estimated accurately with the methods used.

Sources: Hovland et a1. 1982; Weitkamp and McEntee 1982; Parametrix 1984; recent data supplied by $M$. B. Dell, Grant County Public Utility District No. 2, Ephrata, Washington.

Dutmigrants from upriver areas were initially (1977) estimated to travel the 169 kilometers downstream to McNary Dam (through the Hanford Reach and Lake Wallula) in 7 to 15 days, depending on timing and river flow (Faurot 1979). Migration rates were estimated from fish captured, marked, and released at Priest Rapids Dam. Subsequent study revealed that captured and marked fish lingered several days in the release area. Further analys is (1982) indicated 
that the true travel time was 3 days or less for juvenile salmonids actively migrating when they reached Priest Rapids Dam (Weitkamp and McEntee 1982). The rapid migration rate is attributed to swift currents in the Hanford Reach, compared to reduced currents in Columbia River impoundments.

Today, movement of 0 -age group fall and summer chinook salmon from upriver areas occurs through the Hanford Reach over an extended period but typically "peaks" (reaches 50\% of total seasonal passage) in August (Table 3.4, Figure 3.5). 0-age outmigrants passing seaward from above Priest Rapids Dam are usually larger than those produced in the Hanford Reach, indicating that more growth has occurred. The outmigration of the numerically dominant, 1-age spring chinook from upriver peaks near mid-May at Priest Rapids Dam, but extends from April to September (Sims and Miller 1976; 01 son 1981; Hovland et a1. 1982; Weitkamp and McEntee 1982). Most smolts emigrating from upriver apparently pass through the Hanford Reach without lingering in nearshore areas.

Gatewell sampling data indicate that the timing of 0 -age fall chinook salmon outmigration from above Hanford now differs from its timing before dam construction. In 1955, the outmigration of juvenile fall chinook through the Hanford Reach extended from March through July, and there were two distinct downstream movements. The early movement occurred in March and April, and consisted entirely of n-age fry. The second movement occurred in June and July, and consisted largely of 1-age fingerlings (Mains and Smith 1964). The small fry evidently emerged from the gravel and started downstream almost immediately. The larger fingerlings from upstream spawning areas appeared in early July with the first major increase in river discharge.

The 1955 outmigration took place before construction of Priest Rapids Dam in 1959, and before subsequent construction of Wanapum, Rocky Reach and Wells dams above Hanford. The 0-age fish appeared early in 1955, and outmigration was soon completed. In recent years, these fish have appeared later, and outmigration is prolonged. This suggests that conditions in upriver reservoirs may be adverse for small, weakly swimming fry that have recently emerged from streambed gravel.

The horizontal and vertical distribution of juvenile outmigrants in the water column of the Hanford Reach was also examined in 1955. At that time, 

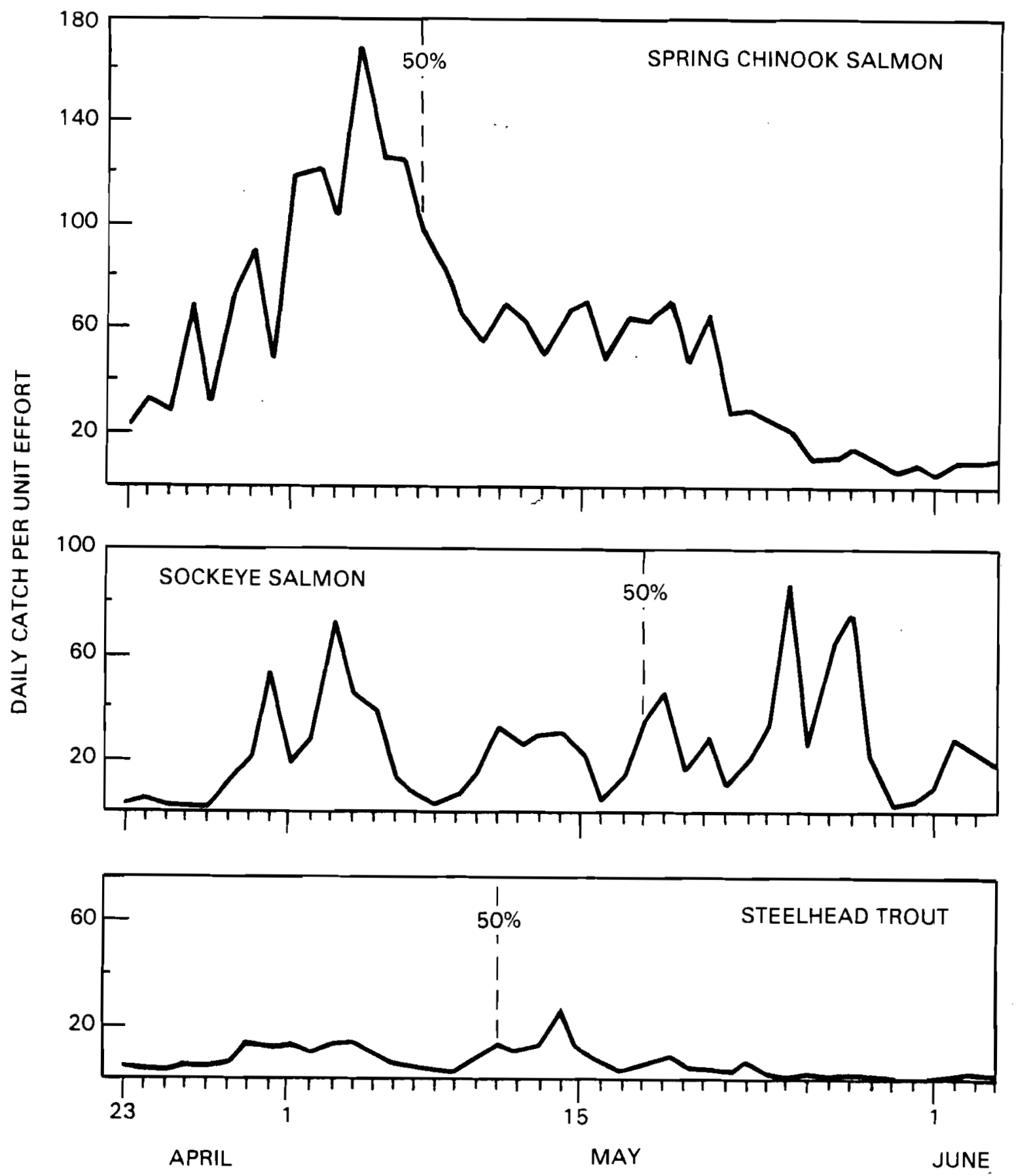

FIGURE 3.5. Outmigration Pattern of Juvenile Spring Chinook and Sockeye Salmon and Steelhead Trout at Priest Rapids Dam in 1982 (after Weitkamp and McEntee 1982) 
stations near the banks accounted for the heaviest catches per unit of effort ( $50 \%$ to $60 \%$ ), but numerous fish were taken at all stations across the river width $(40 \%$ to $50 \%)$. The outmigrants also preferred the surface $20 n e ; 44 \%$ of the catch taken near the surface, $28 \%$ at mid-depth and $29 \%$ near the bottom (Mains and Smith 1964).

In late summer 1983, data were collected on the horizontal and vertical distribution of large, later summer chinook salmon outmigrants in the Hanford Reach. These fish passed primarily through the bottom midchannel area of the river, a finding consistent with studies of large salmonid smolts moving seaward in other rivers (Dauble and Page 1984). Most of these smolts migrated during hours of darkness.

Backwater sloughs and shoreline indentations are temporary foraging sites for 0-age fall chinook in the Hanford Reach (Becker 1973b). Recause currents are reduced in such shoreline areas and many are warmed by insolation, they are favored by fry with limited swimming ability and stamina. Also, food organisms may be more available to fry in shoreline areas than in offshore, mainstream currents.

The major food items of 0-age chinook salmon in the Hanford Reach are aquatic insects, primarily larvae and adult forms of caddisfly (Trichoptera) and midge fly (Chironomidae) (Becker 1973a; Dauble et al. 1980). Feeding trends relate to seasonal availability of different food organisms. Adult caddisfly and midge fly pupae represent the main food itens, by number and volume, of the larger, transitory spring chinook smolts (Gray and Page 1977, 1979a). Caddisfly larvae, fish, spiders and larvae and adult midge flies are also taken. Chinook smolts may prey on smaller chinook fry. Zooplankton, primarily Daphnia, may become important food items for larger outmigrants in June and July.

The normal residence time of emergent fry in shoreline areas of the Hanford Reach is probably brief because progeny of the fall run typically move seaward after spring emergence. Rising water temperatures and high flows in May and June may stimulate outmigration from Hanford. Small numbers of 0-age fry can still be collected in nearshore areas in early july, before water temperatures peak, but virtually all are absent later. 


\subsubsection{Fish Releases}

Two rearing facilities on the Hanford Reach contribute juvenile chinook salmon to the outmigration. One is the spawning channel and hatchery at Priest Rapids Dam, and the other is the Ringold fish-rearing facility at RKM 570 .

A spawning channel was completed in 1963 at Priest Rapids Dam as a mitigation facility for loss of spawning grounds from construction of Priest Rapids and Wanapum dams. However, the channel failed to operate effectively, and both juvenile production and adult returns were poor (Allen and Meekin 1973). It is now used primarily as a rearing facility for juvenile fall chinook salmon produced at the Priest Rapids Hatchery.

The Priest Rapids Hatchery started operation in 1972. It produced an average of 2.6 million (range 1.2 to 5.5 million) 0-age-group fall chinook salmon annually from 1974 to 1982 (Figure 3.6). Production effort was increased dramatically in 1982, and $10.3 \mathrm{million}$ fish were released from the facility in 1983 and 1984. Release usually occurs from mid-May to late June.

Today, juvenile chinook reared at downstream locations are also released at Hanford, e.g., 3.8 million fall chinook salmon from the Ronneville Hatchery in 1984. The goal of fishery management agencies is to increase substantially the number of future spawners, particularly "upriver brights," in the Hanford Reach. These fish will contribute to the commercial, Indian, and sport fisheries.

Artificial production at the Priest Rapids Hatchery depends largely on eggs stripped from adult chinook returning to its fish ladders. Currently, wild fish are also collected from the ladder on the left (east) bank because volunteer returns to the channel and trap on the east bank do not meet hatchery egg quotas. Therefore, annual releases from Priest Rapids represent mixtures of wild and hatchery stocks. Of the fall chinook salmon spawning at Vernita Bar from 1980-1982, an estimated $18 \%$ to $33 \%$ originated at the hatchery (Chapman et a1. 1983). The hatchery fish may tend to concentrate at the upper end of the Hanford Reach near their release site.

The Ringold facility is operated by the Washington Department of Fisheries and Department of Game. Artificial production began in 1962, primarily of fall 


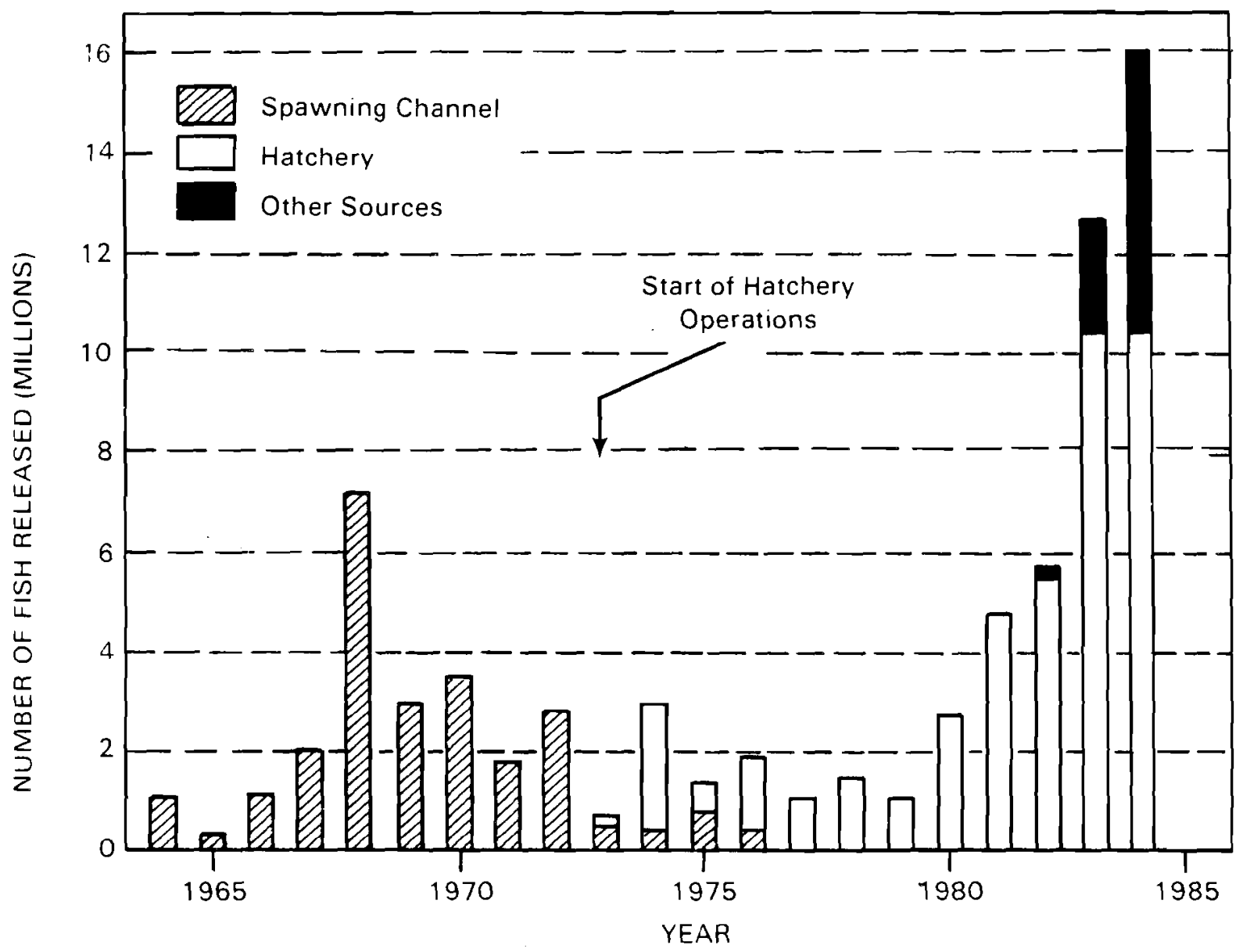

FIGURE 3.6. Releases of Juvenile Fall Chinook Salmon from Priest Rapids Rearing Facilities 1962-1983 (data supplied by M. B. Dell, Grant County Public Utility District No. 2, Ephrata, Washington)

and spring chinook salmon but including some coho salmon and steelhead. Production has varied from year to year (Figure 3.7). Fall chinook salmon are usually released as fry in April, May or June, and spring chinook salmon as yearlings in late winter. Releases of fall chinook yearlings are planned for March 1985 at Ringold.

\subsection{COHO SALMON}

This section describes ecological characteristics of coho salmon runs associated with the Hanford Reach. Population levels of naturally spawning coho salmon in upriver areas are now decimated, and upriver rearing and stocking programs have been de-emphasized. 


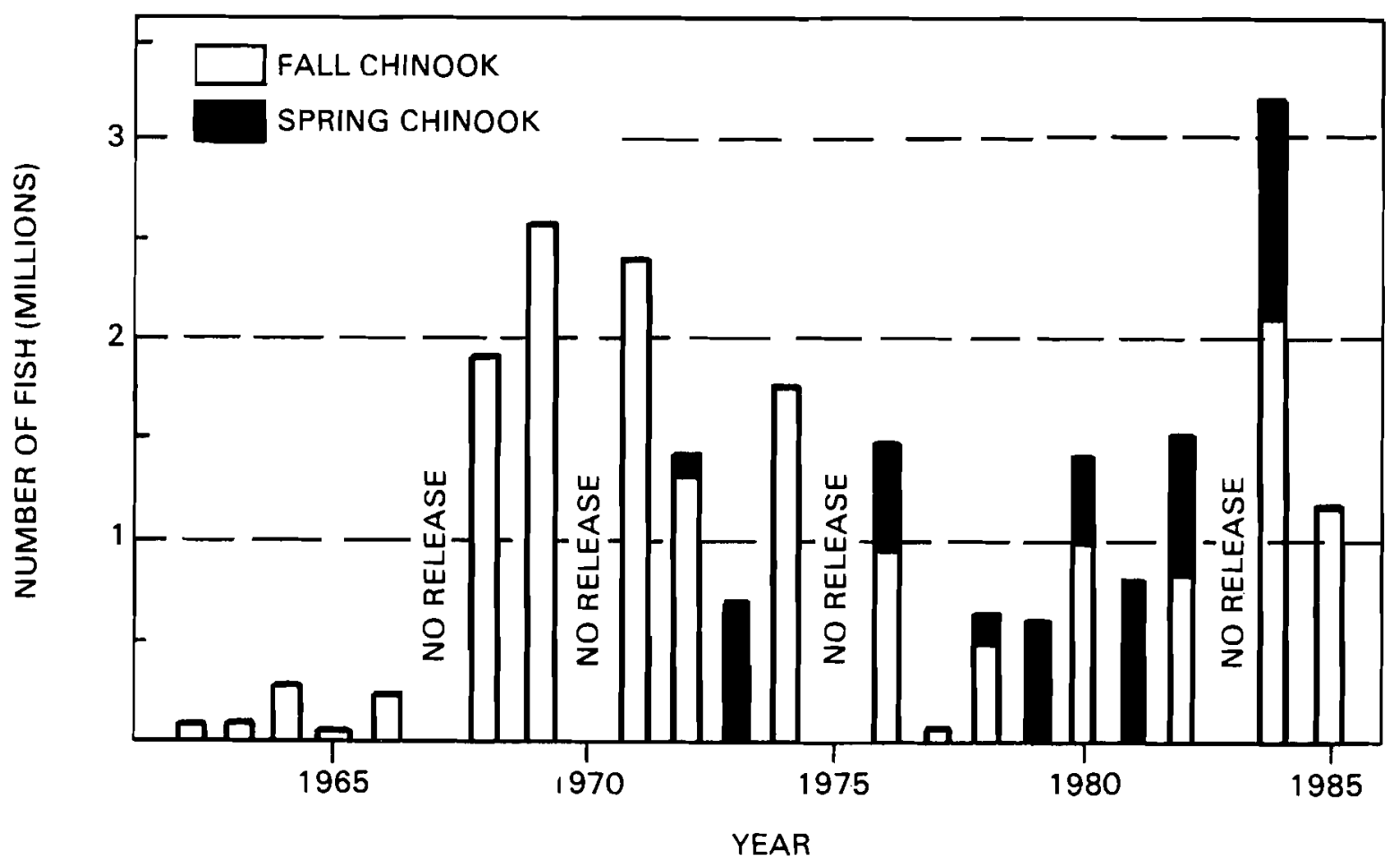

FIGURE 3.7. Releases of Juvenile Chinook Salmon from Ringold Rearing Facilities (data supplied by R. Woodin, Washington Department of Fisheries, 01ympia, Washington)

\subsubsection{Adults}

Historically, adult coho salmon do not spawn in the Hanford Reach. Some migrate through Hanford annually to upstream spawning areas. Coho formerly occurred in several streams of the mid-Columbia River, including the Yakima, Wenatchee and Methow rivers and as far upstream as the Methow River, but were not abundant (Fulton 1970). Early water development projects impacted coho runs because juveniles spend a full year growing in streams before migrating to the ocean (Chapman et al. 1982). Today, most coho salmon entering the Columbia River spawn in small and moderately sized tributary streams below The Dalles Dam (Fulton 1970; Horner and Bjornn 1981a). Population levels are supported by hatchery production because natural runs are depressed (ODFW and WDF 1983).

From 1954 through 1981, those adult coho salmon penetrating upriver passed McNary Dam from August through October, with the peak movement in September (U.S. ACOE 1983). Passage at Priest Rapids Dam occurred a week or two later. Counts of coho adults at Priest Rapids Dam have declined greatly in recent 
years. The counts ranged from 1,000 to 13,000 fish annually from 1966 to 1976 , a result of extensive upriver hatchery production. Counts dropped to less than a thousand for most subsequent years as production was curtailed (Table 3.2 ).

\subsubsection{Juvenile Production}

Natural production of coho salmon in upriver tributaries is limited. Therefore, the number of smolts passing seaward through the Hanford Reach varies primarily in relation to hatchery releases.

Hatchery production of coho above Hanford began in 1942 , but releases did not contribute noticeably to the outmigration until 1966. From 1964 to 1979 , an average of 2.9 million coho smolts (range 400,000 to 9.6 million), including Ringold production, were released annually in the upper Columbia River (Horner and Bjornn 1981a). In response to these releases, over a million coho smolts were estimated to pass seaward over Priest Rapids Dam in 1966 and 1967 (Table 3.5).

TABLE 3.5. Estimated Numbers of Salmonid Smolts Passing Downstream at Priest Rapids Dam 1965-1983, Where Data are Available (estimated by species and run)

\begin{tabular}{|c|c|c|c|c|c|}
\hline Year & $\begin{array}{c}\text { Fall and } \\
\text { Summer } \\
\text { Chinook } \\
\text { (0-Age Group) } \\
\end{array}$ & $\begin{array}{c}\text { Spring } \\
\text { Chinook } \\
\text { (1-Age Group) } \\
\end{array}$ & Coho & Sockeye & Steel head \\
\hline $\begin{array}{l}1965 \\
1966 \\
1967\end{array}$ & $\begin{array}{l}1,700,000 \\
1,400,000 \\
1,500,000\end{array}$ & $\begin{array}{l}170,000 \\
350,000 \\
270,000\end{array}$ & $\begin{array}{r}220,000 \\
1,170,000 \\
1,170,000\end{array}$ & $\begin{array}{l}2,900,000 \\
4,000,000 \\
1,000,000\end{array}$ & $\begin{array}{l}270,000 \\
240,000 \\
266,000\end{array}$ \\
\hline $\begin{array}{l}1976 \\
1977\end{array}$ & $\underset{N D}{2,300}(\mathrm{a})$ & $\begin{array}{l}1,600,000 \\
2,500,000\end{array}$ & $\begin{array}{l}600,000 \\
500,000\end{array}$ & $\begin{array}{l}1,600,000 \\
2,000,000\end{array}$ & $\begin{array}{l}400,000 \\
400,000\end{array}$ \\
\hline $\begin{array}{l}1979 \\
1980 \\
1981\end{array}$ & $\begin{array}{l}\text { ND } \\
\text { ND } \\
\text { ND }\end{array}$ & $\begin{array}{l}2,400,000 \\
3,400,000 \\
3,900,000\end{array}$ & $\begin{array}{l}600,000 \\
300,000 \\
150,000\end{array}$ & $\begin{array}{l}4,000,000 \\
1,200,000 \\
2,300,000\end{array}$ & $\begin{array}{l}350,000 \\
400,000 \\
250,000\end{array}$ \\
\hline 1983 & $1,500,000$ & & & & \\
\hline
\end{tabular}

(a) $\mathrm{ND}=$ No Data; incomplete sampling during outmigration period.

Source: After Park and Bentley 1968; CFWMG 1982; Raemhild et al. 1984. 
The Leavenworth Hatchery complex ceased massive production of juvenile coho salmon in 1974 because of failure to establish a sustaining population in any mid-Columbia tributary streams (Mullan 1982; 1984a). These cutbacks caused the number of outmigrants at Priest Rapids Dam to drop sharply by 1976 and to remain low thereafter (Table 3.5 ). However, some juvenile coho are still released at the Wells Dam Facility, operated by the Washington Department of Game.

The Rocky Reach spawning channels and the rearing ponds at Ringold were the only facilities releasing coho smolts into the upper Columbia River in 1979 (Horner and Bjornn 1981a). The Washington Department of Fisheries recently phased out production of coho salmon in favor of chinook salmon for enhancement of upriver runs. Consequently, the relative abundance of juvenile coho at Priest Rapids Dam dropped to $4 \%$ of all salmonid outmigrants in 1981 and $1 \%$ in 1982 (Table 3.4).

\subsubsection{Outmigration}

Outmigrant coho salmon, primarily 1-age fish, appear at Priest Rapids Dam from April to September with peaks occurring in May (Table 3.4). Juvenile coho move into gatewell collectors at Priest Rapids nam primarily at night (0lson 1981). Migration times of juvenile coho from Priest Rapids Dam to McNary Dam, about 3 days or less, are similar to those of juvenile chinook salmon (Weitkamp and McEntee 1982).

Some coho salmon smolts may overwinter in the Hanford Reach. In spring 1978, several fish were collected at Hanford that appeared to be 2-year-old residents (Gray and Page 1979b). D. D. Dauble (Pacific Northwest Laboratory) suggests that if occasional overwintering occurs, it may represent "residualism" from delayed hatchery release or retarded migration through impounded areas upstream.

The few juvenile coho salmon collected at Hanford consumed primarily fish larvae, midge fly larvae and pupae, and caddisfly larvae and adults (Gray and Page 1979b). Food habits are similar to those of other juvenile salmonids passing through the Hanford Reach. 


\subsubsection{Fish Releases}

Releases of coho salmon at Hanford are limited. At the Ringold rearing facility, production records show four releases of yearling coho from 1969 to 1972, which consisted only of 130,000 to 320,000 fish. The last release was made in 1978, a large group of $1,102,000 \mathrm{fish}$.

Releases at Ringold and elsewhere in the upper Columbia River have consisted almost entirely of mixed early- and late-run coho salmon stocks from the lower Columbia River. Thus, the gene pool of the upriver run was greatly altered (Horner and Bjornn 1981a). Use of inappropriate stocks may have adversely affected the survival of upriver coho runs.

\subsection{SOCKEYE SALMON}

This section describes ecological characteristics of sockeye salmon runs associated with the Hanford Reach. Population levels of sockeye salmon above Hanford now depend entirely on the success of natural spawning in a few streamlake ecosystems.

\subsubsection{Adults}

Adult sockeye salmon, like coho salmon, do not spawn in the Hanford Reach, but migrate through it annually to upstream spawning areas. Virtually all adult sockeye entering the lower Columbia River today are destined for the upper reaches, where the major production areas are Lake Wenatchee on the Wenatchee River and Lake Osoyoos on. the Okanogan River (Allen 1977; ODFW and WDF 1983).

Historically, sockeye salmon returning to the Columbia River were already reduced to a remnant run by the time Grand Coulee Dam was built. The depletion resulted from overharvesting and the damming of rearing lakes (Chapman et a1. 1982). Grand Coulee Dam blocked access to more rearing lakes, particularly those in Canada (Fulton 1970; Mullan 1984b), and lakes in Idaho were subsequently blocked by dams built on the Snake River system.

The Leavenworth National Fish Hatchery (Wenatchee River system) was developed as a mitigation facility for loss of sockeye spawning areas. However, artificial production at this facility was discontinued in 1965 (Wahle et al. 
1979; Allen and Meekin 1980). Consequently, the last major runs of adult sockeye salmon passed McNary Dam in 1966, 1967 and 1968, when they averaged 127,000 fish (U.S. ACOE 1983). There was no commercial sockeye harvest in the lower Columbia River from 1972 to 1983, but a limited season was permitted in 1984 . Runs of sockeye over Priest Rapids Dam surged upward in 1983 and 1984 (Table 3.2).

Adult sockeye salmon pass upstream through the Hanford Reach primarily from June to early September, peaking in July (U.S. ACOE 1983). Since 1979, counts at Priest Rapids Dam have declined, to range from 40 to 50 thousand fish (Table 3.2). Counts of adult sockeye at Priest Rapids Dam are usually higher than counts at MCNary Dam (U.S. ACOE 1983). Since very few sockeye divert to the Yakima River or Snake River, the counts should be nearly equal. Operation of the locks at McNary Dam for barge and boat traffic may permit uncounted sockeye salmon to pass upriver.

\subsubsection{Juvenile Production}

The number of sockeye salmon smolts passing seaward each year through the Hanford Reach now depends entirely on natural reproduction of upstream runs. Sockeye alevins emerge from gravel in April and May, and enter nursery areas in lakes for 1 to 3 years before outmigration (Foerster 1968).

For over 25 years, starting in 1940, large numbers of sockeye smolts were produced at the Leavenworth Hatchery Complex and released in Lake Wenatchee. However, production was abandoned in the late 1960's because of a low 0.04 benefit/cost ratio (Wahle et al. 1979) and severe problems with sockeye salmon virus disease. Some year classes experienced catastrophic losses from the virus, for which there is still no known control (Mullan 1984b).

Estimates of smolts passing Priest Rapids Dam from 1965 to 1982, when data are available, range from 1.0 to $4.0 \mathrm{milli}$ ion (Table 3.5 ). Proportionately, sockeye salmon smolts now represent $20 \%$ to $48 \%$ of all smolts taken in gatewell collections at Priest Rapids Dam (Table 3.4). The contribution of naturally spawning sockeye to the total smolt outmigration remains substantial. 


\subsubsection{Outmigration}

Peak outmigration ( $50 \%$ total passage) of sockeye salmon smolts at Priest Rapids Dam usually occurs in May (Table 3.4), but seasonal movement varies (Figure 3.5). Smolts enter the gatewells at Priest Rapids Dam at all hours of the day, but greatest numbers appear in the afternoon (01son 1981). In terms of relative abundance, numbers of sockeye smolts are usually second to those of chinook salmon in gatewell collections.

Young sockeye salmon feed primarily on zooplankton and phytoplankton in lake nursery areas (Foerster 1968). This preference for plankton is in contrast to the more insectivorous habits of other juvenile salmonids. However, gut analysis from a few sockeye smolts taken at Hanford showed primarily midge fly and caddisfly pupae (Gray and Page 1979a).

The few juvenile sockeye salmon collected at Hanford in June and July (Gray and Page 1979a; Page et al. 1982) represent outmigrants. The Hanford Reach is not a nursery area for juveniles.

\subsubsection{Fish Releases}

No sockeye salmon are artificially reared and released in the Hanford Reach.

\subsection{STEELHEAD}

This section describes ecological characteristics of steelhead runs associated with the Hanford Reach. Population levels of steelhead at Hanford and above Priest Rapids nam now appear to be related to the success of artificial rearing and release programs, combined with habitat improvement in tributaries used for spawning.

\subsubsection{Adults}

Both resident and anadromous forms of steelhead occur in the Hanford Reach. Based on the time that adult anadromous forms appear in the lower Columbia River, they are classified either as winter or summer run. The winter run enters the Columbia River from November through April and spawns primarily 
in tributaries below Bonneville Dam. The summer run enters the river from April through October and spawns primarily in areas above Bonneville Dam (Fulton 1970).

The summer steelhead run is further represented by two groups. The first appears from June to early August, and travels to tributaries throughout the system. The second appears from August to October, and travels to tributaries in the Snake River (ODFW and WDF 1983). Although the upriver runs migrate at different seasons, they both spawn during the winter and spring (Fulton 1970).

Adult steelhead show peak periods of migration through the Hanford Reach, but some migrants are passing through, holding, or spawning at Hanford throughout the year. An upriver run occurs over McNary Dam below Hanford from April through October, but peak movement occurs in August and September (U.S. ACOE 1983). The migration of steelhead over McNary Dam from 1971 to 1982 averaged about 11,000 in August and 24,000 in September. Many of these fish were destined for the Snake River.

The steelhead migration at Priest Rapids Dam above Hanford also peaks in August and September. However, more adult steelhead pass over Priest Rapids Dam and Ice Harbor Dam in October, April and May than over McNary Dam. This suggests that some adult steelhead pause in the Hanford Reach during late fall or winter before continuing their upstream migration (Watson 1973).

From 1962 to 1971, the number of adult steelhead passing Priest Rapids Dam averaged 9,700 fish (Watson 1973). From 1972 to 1982, the numbers passing the same site ranged from 2,000 to 11,000 and averaged about 7,000 fish (Table 3.2). Thus, recent returns have been sustained with some year-to-year variations. In 1983 and 1984, the number of steelhead passing Priest Rapids Dam more than doubled (Table 3.2). This sudden increase is likely due to recent stocking, enhancement and management practices, and to improved spring spill programs that aid survival of downstream migrants.

In addition to runs passing upriver over McNary and Ice Harbor dams, about 10,000 to 15,000 steelhead enter the Yakima River each year, about 4,000 to 5,000 enter the Walla Walla River, and about 2,700 are taken regionally by sport fishermen (Watson 1973). Assuming $20 \%$ mortality for missing fish, an 
average of about 10,000 steelhead may have spawned annually in the Hanford Reach from 1962 to 1971. However, there are no firm data to support this estimate. Steelhead have been reared and released at the Ringold Hatchery since 1962, and a significant sport fishery now occurs on returns to this facility (Allen 1977).

Steelhead collected in the Hanford Reach are usually 3 to 4 years old (U.S. DOE 1982). Since most steelhead in the Mid-Columbia River are produced in hatcheries, they will have only one freshwater annulus when released as smolts.

Steelhead spawn in the Hanford Reach from February through May, from the mouth of the Yakima River to Priest Rapids Dam (Fulton 1970; Watson 1973). Gravid females have been collected at Hanford in late April and early May, spent males in August, and a spent female in February (Page et al. 1976; Gray and Page 1977). Some steelhead and rainbow trout have been collected at Hanford throughout the year.

The portion of steelhead that survive to spawn again is usually small. Repeat spawners range from $5 \%$ to $31 \%$ in some British Columbia streams (Withler 1966), and from 4.4\% to 14\% in Washington State (Wydowski and Whitney 1979). Because of fish passage problems at dams (Collins et al. 1975), the number of adult steelhead that reach the sea and return to spawn a second time at Hanford is probably low.

Estimates of steelhead spawners in the Hanford Reach by aerial enumeration of redds are complicated by high flows and turbidity during the late winter spawning period (Watson 1973). Several sites appear to provide suitable conditions for spawning and egg incubation (Figure 3.8). However, only a few steelhead redds have been detected in the Hanford Reach, primarily in the section extending from Ringold to Priest Rapids Dam.

\subsubsection{Juvenile Production}

Juvenile steelhead usually spend 1 to 3 years in freshwater before passing seaward during the spring and summer. Steelhead outmigrants at Priest Rapids Dam ranged from 240,000 to 400,000 annually during certain years from 1965 to 
A

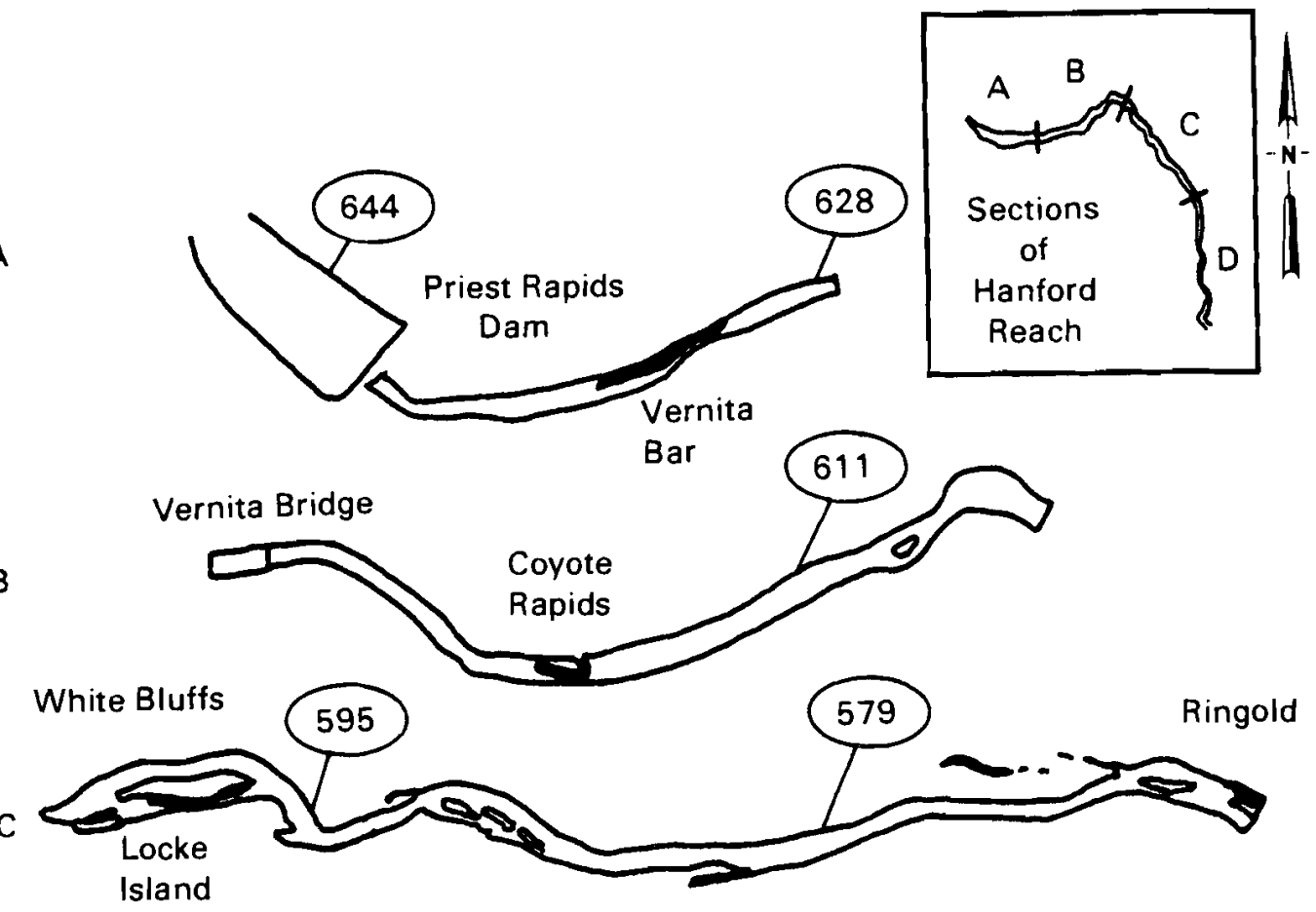

B

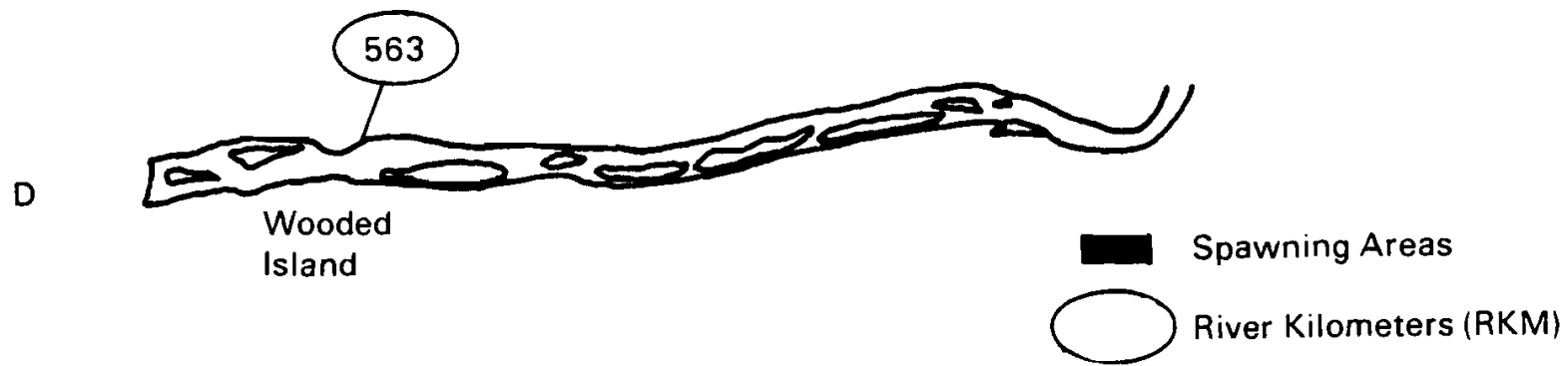

FIGURE 3.8. Likely Spawning Areas for Steelhead in the Hanford Reach (after Fickeisen et al. 1980)

1982 (Table 3.5). Proportionately, steelhead represent from $6 \%$ to $22 \%$ of the annual smolt outmigration at Priest Rapids Dam (Table 3.4).

The total estimated number of steelhead smolts passing seaward from the Hanford Reach each year has been between 2.0 and 2.2 million (Fickeisen et a). 1980). This represents the sum of the outmigration from above Priest Rapids Dam, the contribution from natural spawning in the Hanford Reach, and hatchery releases at Ringold. 


\subsubsection{Outmigration}

The outmigration from above Priest Rapids Dam generally occurs from midApril to early July (Figure 3.5), with a peak (50\% total passage) in May (Table 3.4). Smolts have been collected at Hanford from April through June with peak catches in May (Gray et al. 1976; Gray and Page 1978, 1979a). Marks indicate that most of these fish were produced at upriver hatcheries.

Diel migration patterns of salmonid outmigrants at Priest Rapids Dam tend to vary. Initial studies indicated that most steelhead smolts $(61 \%)$ entered the intake gatewells after dark (Sims and Miller 1976). Recent studies indicate variable movement rates at night and a strong movement after sunrise (01son 1981). In the Snake River, most steelhead smolts (76\%) move from impounded waters at night, and the portion collected in the lighted surface zone (0 to 7.3 meters) declines from day $(74 \%)$ to night (36\%), reflecting this movement (Smith 1974). Steelhead smolts passing downstream at Priest Rapids Dam probably move directly through the Hanford Reach to Lake Wallula and beyond.

Although several thousand adult steelhead potentially spawn at Hanford, few fry have been collected there despite extensive effort (Fickeisen et al. 1980; U.S. DOE 1982). In contrast to chinook fry, steelhead fry apparently do not occupy shoreline areas to any extent at Hanford. This difference may reflect the relative abundance of adult chinook salmon and steelhead spawners.

\subsubsection{Fish Releases}

Juvenile summer-run steelhead are produced at the Ringold Facility. From 146,000 to 201,000 smolts were released annually in the Hanford Reach from 1980 to 1984, usually in April and May (Figure 3.9). The releases represent about $25 \%$ of the steelhead smolts reared artificially from Hanford upstream to Wenatchee (Fickeisen et al. 1980). Most Ringold releases remain locally for about a month, and a few overwinter in the Hanford Reach (Gray and Page 1978). 


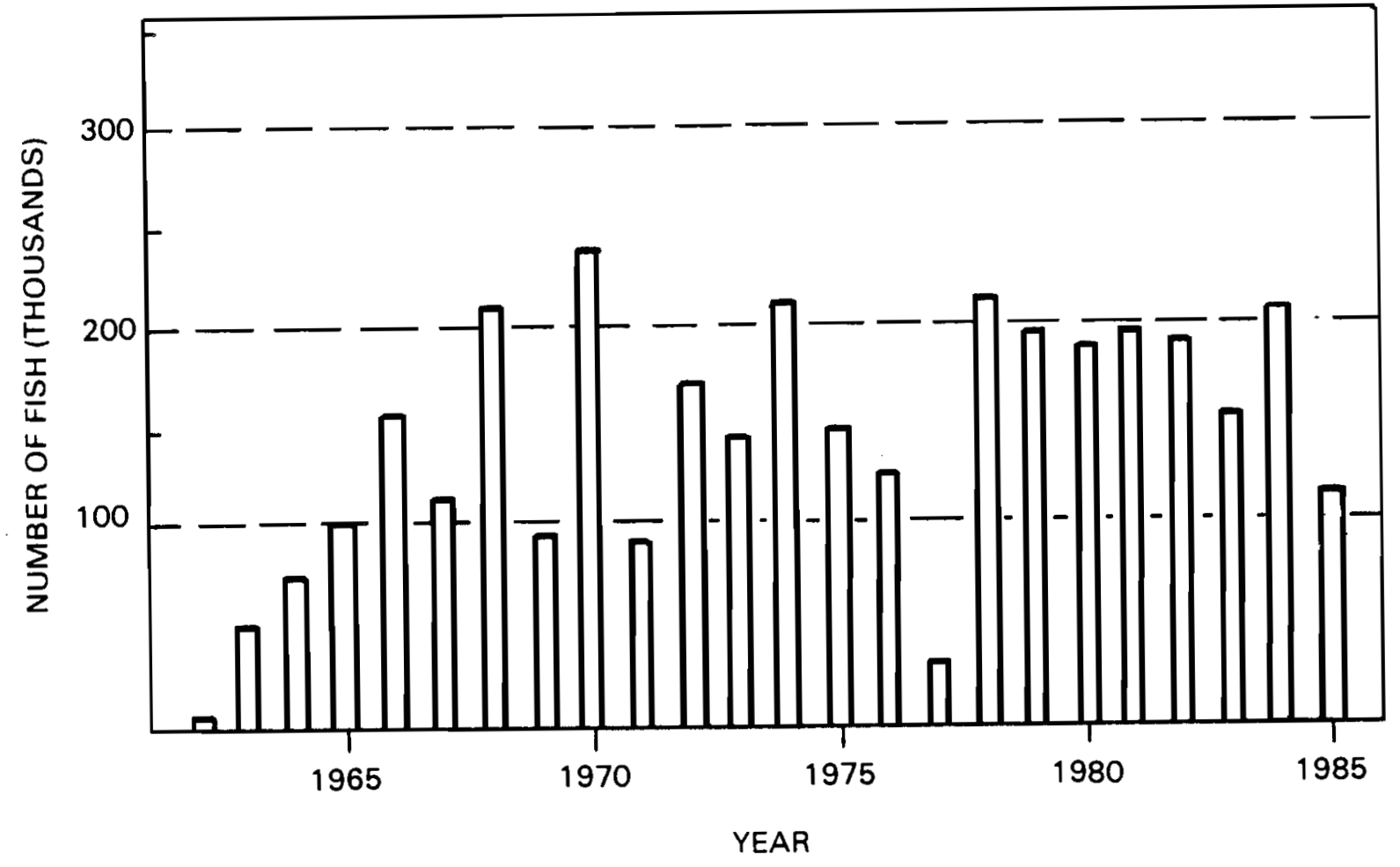

FIGURE 3.9. Releases of Juvenile Steelhead from Ringold Rearing Facilities (data supplied by J. Gearheard, Washington Department of Game, 01 ympia, Washington) 


\subsection{POTENTIAL HABITAT MODIFICATIONS}

A number of present and potential activities could alter the Columbia River habitat in such a way as to adversely affect populations of fall chinook salmon, steelhead and other salmonids associated with the Hanford Reach. These activities can be placed into two general categories: present and possible future activities on the Hanford Site (onsite), and regional growth and development activities in the mid-Columbia River Basin (offsite). Some illustrative examples are briefly discussed in this section. Historical and other background information is provided for perspective on cause-and-effect relationships.

\subsection{HANFORD SITE (ONSITE) ACTIVITIES}

Several contractors now operate various facilities in the 1,476-squarekilometer (570-square-mile) expanse of the Hanford Site, where public access is restricted. Considerable research and development work is sponsored by the U.S. Government through the Department of Energy, with emphasis on nuclear energy technology. A dual-purpose reactor at RKM 611 produces both plutonium (the $N$ Reactor) and electrical power (the Hanford Generating Project or HGP). Other operations sponsored by the government at Hanford in 1984 include a fastflux (sodium) test facility, a basalt waste storage project, a chemical extraction facility for spent nuclear fuel (PUREX), and defense waste management. Emissions of radioactive, hazardous or other materials from plant operations are prevented or kept within Federal guidelines, and monitoring is conducted to detect any fugitive releases to air and offsite water.

At this time, these onsite activities have negligible effects on aquatic resources of the Hanford Reach, largely because operations adhere to protective environmental regulations. For example, chemical and radioactive emissions to air and water are kept well within conservative regulatory standards. Environmental monitoring programs are conducted to assure compliance. Existing federal and state regulations require that the effects of all major construction and operation activities on the Hanford Site be assessed to ensure against 
environmental deterioration. These regulations also require that potential impacts on the environment and its biota be minimal. Three activities at Hanford that illustrate carefully monitored events are first reviewed. They are emissions of heat and radionuclides, and operation of the HGP. Discussion of these existing "controlled" activities is followed by review of a potential future onsite activity at Hanford, a multi-unit power plant complex.

\subsubsection{Direct Releases of Heat and Radionuclides to the River}

The Hanford Site was established in 1943-1945 to produce nuclear materials, primarily plutonium, during World War II. Between 1944 and 1964, the Columbia River at Hanford also received heat from the cooling water discharges of up to nine plutonium production reactors. In 1964 (the last year during which all units were operated), loading from these sources exceeded 23,000 megawatts thermal (MWt) when all reactors were operated at average levels (U.S. DOE 1982). Temperatures of each reactor effluent at the point of discharge then generally exceeded $85^{\circ} \mathrm{C}\left(185^{\circ} \mathrm{F}\right)$. All reactors operated with direct, oncethrough cooling, and discharges were through vertical outfalls to the center of the Columbia River.

These conditions no longer exist. The last single-purpose plutonium production reactor was deactivated in early 1971. Today, discharges to the Columbia River adhere to requirements of a National Pollutant Discharge Elimination System (NPDES) permit. Most heat from the $N$ Reactor is transferred to the HGP as steam for production of electricity in its normal, dual-purpose, operational mode. The $N$ Reactor and HGP, operating simultaneously, release 3,100 MWt to the river. If the $N$ Reactor were operated in a single-purpose mode, about 4,000 MWT would be passed to the Columbia River (U.S. DOE 1982; Ecker et al. 1983). Thus, thermal releases to the Columbia River at Hanford today are many times less than thermal loads discharged from the original plutonium production reactors.

Until early 1971, cooling water discharges from the plutonium-production reactors released radioactive materials directly to the mid-Columbia River. Most of these materials were not fission products from the splitting of uranium and plutonium atoms, but isotopes from neutron bombardment of elements in the cooling water or in the reactor piping (Foster et al. 1961; Foster 1972). 
However, trace amounts of irradiated fuel were occasionally passed to the Columbia River through the cooling water discharge (Robertson and Fix 1977).

Monitoring during those early years revealed no adverse effects from radionuclides on fishery resources of the Columbia River, and exposures to humans were well within acceptable limits (Foster 1972). After cessation of cooling water discharges, measurable concentrations of radioactive materials in the Hanford Reach decreased to extremely low or unmeasurable levels within 1824 months (Cushing et al. 1981), although, the deeper sediment deposits in downstream reservoirs still retain low concentrations of the long-lived radionuclides (Nelson and Haushild 1970; Haushild et al. 1975; Robertson and Fix 1977). The $\mathbb{N}$ Reactor, which operates today (the only plutonium-producing reactor now operating), has a closed primary cooling loop, and bleed-off from this loop is passed through a liquid effluent control system. Therefore, direct release of radioactivity from the $N$ Reactor to the Columbia River is limited.

\subsubsection{Indirect Releases of Radionuclides Through Groundwater}

In the early days of the Hanford operations, large volumes of process cooling water contaminated with low-level radioactivity were generated from processing of irradiated materials to extract uranium and plutonium. Most of the contaminated liquid was deliberately allowed to infiltrate the ground. The ion exchange properties of the soil selectively removed much of the radioactivity, and concentrations were further reduced by diffusion, radioactive decay, and dilution (Sula et al. 1983). Since the liquids tended to move downward and laterally through the soil, some of the more mobile radionuclides reached the unconfined aquifer representing groundwater under the Hanford Site. At present, radioactive decay in the groundwater is proceeding faster than new radioactivity is being added.

The intrasoil movement of radionuclides on the Hanford Site has been closely monitored over the years (ERDA 1975; Eddy et al.. 1983; Greager 1983; Wilbur et al. 1983; Law and Allen 1984) and continues today. Movement of the contaminated groundwater plume is gradually east and southeast towards the Columbia River. Some groundwater entering the Columbia River at Hanford now contains low-level radioactivity, particularly the mobile (but short-lived) 
element tritium. The monitoring program clearly shows that amounts of radioactivity entering the river, while measurable, are well below DOE concentration guides (Sula et al. 1983; Price et al. 1984). Further, the groundwater contribution of radioactivity is diluted by Columbia River water, and soon becomes indistinguishable from radioactivity contributed by natural sources and atmospheric fallout (WSDOE 1980).

All waste management operations at Hanford adhere to Federal and state regulations. Radiation releases to air and water are very low and present no significant hazard to public health and safety (WSDOE 1980; Sula et al. 1983). Today, shutdown of the original production reactors and addition of liquid effluent control systems at $N$ Reactor have substantially reduced direct both heat and radionuclide discharges to the Columbia River (Price et al. 1984).

\subsubsection{Operation of a Steam-Electric Plant}

The Hanford Generating Project (HGP) at RKM 611 is a steam-electric power plant owned and operated by the Washington Public Power Supply System (WPPSS). Steam for the HGP's turbine generators is produced by the $N$ Reactor. Water for once-through cooling of HGP condensers is drawn from the Columbia River. Depending on pumping mode, the temperature of the cooling water (not the discharge plume) may increase $19^{\circ}$ to $24^{\circ} \mathrm{C}$ (Neitzel et al. 1982C). Three potential impacts on salmonids are associated with this type of power generation: entrainment through the plant cooling system, impingement on plant intake screens, and thermal shock from encountering the heated discharge plume.

However, entrainment of juvenile salmonids is not a problem at HGP because these fish are too large to pass through the revolving intake screens. Moreover, impingement on the HGP intake screens was examined and found to be relatively low, except for 0-age group fall chinook salmon (Page et al. 1977, 1978). Implementation of a live fish return and a continuous screen wash on the intake screens has now reduced impingement of these fish to almost zero.

Migrating salmonids may be thermally shocked if they encounter elevated temperatures of a midstream discharge plume. The HGP must have an NPDES permit, but is exempt from federal requirements for closed-cycle cooling systems 
because of its age under Section 316 (a) of the Federal Water Pollution Control Act, as amended by the Clean water Act of 1977 (Greenwood et a1. 1979). However, state water quality standards still apply. Studies showed that the thermal discharge from HGP exceeded state water quality standards under certain conditions of water temperature and flow.

To establish a scientific basis for evaluating the impacts of cooling water discharges, research has been conducted on indigenous aquatic populations of the Hanford Reach for over 5 years (Page et al. 1976; Gray et al. 1976; Gray and Page 1977, 1978, 1979a, 1979b). Findings were presented in a 316 (a) report (WPPSS 1978), which demonstrated a general absence of appreciable harm to aquatic resources of the Hanford Reach (Neitzel et al. 1982c). As a result, the Washington State Department of Ecology, with the concurrence of Region $x$ EPA, granted a waiver of state thermal discharge limits for HGP, with one exception. After 1983, discharge of heated water from HGP to the Columbia River is prohibited each year from July 1 to September 7 , when ambient water temperatures are high, flows are low and the smolt outmigration is underway.

\subsubsection{Multi-Unit Power Plant Complex at Hanford}

Some long-range plans envision the Hanford Site as a future multi-unit power plant complex (Harty and Dowis 1983). Power plants under construction or planned on the Hanford Site must prepare environmental impact statements and comply with Federal and state regulations designed to minimize environmental impacts. WPPSS Nuclear Projects 1, 2, and 4 are sited at RKM 566, about 19 kilometers north of Richland. In 1982, Projects 1 and 4 were mothballed because of reduced projections of future power demand and escalating costs. In 1983, Project 2 entered the testing stage, and it reached full operation in the fall of 1984. The plants are provided with intake structures designed to minimize impingement and entrainment of fish. Recause these plants have closed-cycle cooling and mechanical draft cooling towers, they require considerably less cooling water than plants with direct, once-through cooling. Limited amounts of tower makeup water are drawn from the Columbia River, and some tower blowdown enriched in dissolved solids and containing trace amounts of chlorine residuals is returned to the river (U.S. NRC 1975). 
Adherence to Federal and state regulations is a requirement of the planning, construction, licensing, and operational phases of all power plants in the United States today. Potential environmental impacts of individual plants on regional locales receive close scrutiny. Each current WPPSS project was designed to protect the ecosystem and biota of the Hanford Reach. Thus, WPPSS Project 2, as it is currently operating, is expected to have minimal impact.

A multi-unit complex would present a different environmental situation. Stresses from several plants operating simultaneously might be cumulative on aquatic resources of the Hanford Reach. The effects of combined operational stresses would intensify under chronic, low-flow conditions associated with over-allocation of river water.

Fortunately, anadromous salmonids and other aquatic biota are considered in the assessment and operational phases of all onsite major programs as required by federal and state laws. Environmental requirements make it unlikely that activities on the Hanford Site will alter physical and chemical characteristics of the adjacent Columbia River sufficiently to impact valued fishery resources.

\subsection{REGIONAL (DFFSITE) ACTIVITIES}

The effects of offsite factors are currently minimal, but could intensify as growth and development continue in the mid-Columbia Basin. Some regional changes now being considered have potential future impact, and a number of them are described below. Regional activities include flow fluctuations from peaking power generation at upriver dams, construction of a low-head hydroelectric dam above Richland, reductions of instream flows from irrigation and other diversions, and dredging and commercial navigation in the Hanford Reach.

\subsubsection{Peaking Power Generation at Upriver Dam}

Water level fluctuations are a common result of hydroelectric power generation in western rivers (Geen 1974; Bayha and Koski 1974; Haber et al. 1978; Hildebrand et al. 1980). In the Columbia River system, increased use of 
the peaking mode of power generation and the addition of generating units at dams tend to increase the frequency and extent of water level fluctuations (Bell et al. 1976).

Except for Lake Roosevelt behind Grand Coulee Dam, mid-Columbia River reservoirs have only limited capacities for water storage. Lake Roosevelt can store 5.2 million acre feet. In contrast, the total capacity of all "river run" reservoirs from Hanford to Grand Coulee Dam is only 0.41 million acre feet. Therefore, the whole mid-Columbia reservoir system from Chief Joseph to Priest Rapids is driven by the hydraulic and storage capacities of Grand Coulee Dam. When Priest Rapids Dam is operated to provide maximum power generation during periods of maximum power demand (power peaking), water levels in the Hanford Reach vary hourly. Because storage capacity behind Priest Rapids Dam is limited, daily and weekly fluctuations in water level at Hanford are due to a combination of Priest Rapids operation and systematic releases originating at Grand Coulee Dam.

Water levels in the Hanford Reach can vary up to 2 or 3 meters (6.6 or 9.8 feet) daily (U.S. ERDA 1975; WPPSS 1978). Water level fluctuations cause stranding of adult and juvenile fish along shorelines subject to alternating flooding and dewatering. Young 0 -age fall chinook salmon produced in the Hanford Reach are susceptible to stranding during the spring months (Becker et al. 1981). The spawning of adult fall chinook salmon at Vernita Bar during October and November may also be affected (Bauersfeld 1978). Spawning at high flows can lead to exposure and dewatering of redds at low flows.

Considerable field and laboratory research has been conducted to eliminate or minimize effects on chinook salmon spawning from operation of Priest Rapids Dam (Parametrix, Inc. et a1. 1979; Chapman et a1. 1981, 1983; Weitkamp et al. 1982; Neitzel et a1. 1984). This research has identified operational techniques that permit successful spawning of fall chinook salmon, and has examined intergravel conditions that promote survival of eggs and alevins during periodic drawdowns. The ecological information obtained from this research, properly applied, will make power generation at Priest Rapids Dam compatible with spawning requirements of adult salmonids and minimize impacts on intragravel development of eggs and alevins. 


\subsubsection{Potential Hydroelectric Dam on the Hanford Reach}

One alternate use of the Hanford Reach considered by the U.S. Army Corps of Engineers is construction of a dam (the proposed Ben Franklin Dam) above Richland at RKM 560. The dam would have a nominal full-pool elevation of 122 meters above mean sea level, impound the present flowing river to Priest Rapids Dam, and convert most of the Hanford Reach to a run-of-the-river reservoir (U.S. ACOE 1969).

A number of ecological impacts would result from dam construction and operation. The dam would inundate most spawning and rearing areas of anadromous salmonids in the Hanford Reach and virtually eliminate the surviving run of fall chinook salmon. It would also reduce the survival rate of spring and summer chinook, coho, and sockeye salmon produced above Hanford; destroy steelhead spawning and rearing habitat; inundate ponds used to rear salmonids at Ringold; and contribute directly to other impacts from environmental alteration (Harty 1979; Fickeisen et al. 1980). The additional reservoir created behind the dam would further slow the seaward migration of juvenile salmonids and perhaps adversely affect the critical smoltification process (Wedemeyer et al. 1980).

At the present time, plans for constructing the dam have been shelved because of adverse environmental impacts and an unfavorable cost/benefit ratio. The possibility remains, however, that a dam might be constructed on the Hanford Reach in the future if societal needs and perceptions of value change.

\subsubsection{Irrigation and Instream Flow Reduction}

The primary consumptive use of Columbia River water is for agricultural irrigation, and this use will probably increase in future years. However, other factors contribute to periodic low flows in the Columbia River ecosystem. The adverse ecological effects resulting from withdrawal of water and low river flows are complex.

Instream flow reduction in the Columbia River has become a concern of the U.S. Army Corps of Engineers (U.S. ACOE 1976a, 1976b), as well as fishery management agencies (NPPC 1982). Instream flow reduction results from withdrawal of water for irrigation or pumped storage projects, and storage of water in 
upriver reservoirs to enhance irrigation or power generation. Diverting large quantities of Columbia River water to the southwestern United States remains a possibility. Offstream pumping to a storage reservoir is also planned as a mitigation measure to help maintain flows in a salmon-producing tributary, the Umatilla River.

Today, the largest consumptive user of Columbia River water is the Columbia Basin Irrigation Project, which now irrigates about 530,000 acres, or about half of the project's full estimated potential. Some irrigation water is returned to the Columbia River via surface runoff and underground seepage. However, quality of water used for irrigation can be impaired through the addition of fertilizers, pesticides, other chemicals, and organic wastes. Measures to maintain water quality are not required because a 1977 amendment exempts agricultural waste water from requirements of the Clean Water Act.

A related feature of irrigation along the middle and upper Columbia River is infiltration of soil layers by moisture, which increases the likelihood of mudslides on steep slopes. Several slides have recently occurred on the high east bank of the Hanford Reach in Franklin County, presumably from soil supersaturation. Mudslides increase turbidity, lowering the quality of river water below the site, and may affect the upstream migration path of adult salmonids.

Fish passage problems at dams for adult and juvenile salmonids become acute during low-flow years. Also, water rights for irrigation are subject to maximum allocation during drouth, a societal factor that complicates a power and fishery management problem.

Mortality of outmigrating salmonids is high when most of the spring and summer river discharge is passed through power-generating turbines (Collins et al. 1975). For example, flow/survival estimates for yearling chinook salmon at Bonneville Dam were developed by fishery agencies for comparisons between 1979 (average flows 255,000 cfs), 1980 (261,000 cfs) and 1981 (215,0n cfs). Survival was nearly doubled by increasing flows from 215,000 to 260,000 cfs (CRWMG 1982).

The problem of passing adult salmonids upriver through fishways at dams is also compounded during low-flow periods (Collins et al. 1962; Weaver 1963; 
Leman and Paulik 1966; Bell et al. 1976). Adults may be prevented from entering fish ladders, and upstream migration is slowed. Moreover, water temperatures above normal are associated with low flows during the summer and fall. Low flows and warmer river temperatures increase the threat of infectious disease from such pathogens as Flexibacter columnaris to returning adult fish and possibly to seaward migrants (Becker and Fujihara 1978).

Today, after extensive development, the Columbia River can no longer be viewed as a surplus resource. Future commitments of water will cause adverse effects on other river uses (U.S. ACOE 1976a). The impact of low flows on anadromous salmonid resources of the mid-Columbia River remains a valid environmental concern (U.S. ACOE 1976b). Part of the recommended solution is a water budget that provides a minimum flow based on forecasted runoff for January through July at selected dams, including Priest Rapids nam. The water budget was created primarily to protect salmonid outmigrants (NPPC 1982).

In the past, anadromous salmonids have received low priority in conflicts among users of Columbia River water. However, the Northwest Power Planning Council, established on Apri1 28, 1981, pursuant to the Pacific Northwest Flectric Power Planning and Conservation Act of 1980 (Public Law 96-501), changed this situation. The Council is required by law to develop and conduct a comprehensive program to protect, mitigate, and enhance fish and wildlife along the Columbia River and its tributaries (Hemmingway 1983). Maintenance of instream flows during smolt outmigration via the water budget, combined with habitat improvement projects, are mitigation methods developed for this purpose.

\subsection{DREDGING AND COMMERCIAL NAVIGATION}

Sporadic efforts have been made to obtain federal funding for navigation locks in Priest Rapids Dam and other upstream dams as far as Wenatchee, and to dredge the Hanford Reach to enhance comnercial traffic. Excavation of a navigation channel through Hanford would alter the existing river channel, and would destroy sections of the stream bed with a gravel composition uniquely suited for salmonid spawning. A number of other impacts can be projected (Allen and Hardy 1980; Simpson et al. 1982). For example, the biomass of 
benthic invertebrates available for fish food would be reduced. Dredge spoils deposited on the bank would alter or destroy existing riparian habitats, and bow waves from large navigation vessels would continually wash the shoreline, resuspend silt, and strand juvenile fish. Therefore, excavation and use of the Hanford Reach for commercial navigation is incompatible with the spawning of salmonids.

In January 1980 the U.S. Army Corps of Engineers held an open discussion on two "management plans" for the Hanford Reach (Ben Franklin Dam and navigation), along with two alternatives. The alternatives were to retain present river management policies or to classify the Hanford Reach as a "wild and scenic river." Present river management policies may be adequate for maintaining salmonid populations in the Hanford Reach. A "wild and scenic river" classification, which includes construction of limited public access and recreational facilities, might increase public use. However, additional protective regulations would then 1 imit further encroachment. 


\subsection{ASSESSMENT}

The anadromous species most likely to be affected by human-induced modifications of habitat in the Hanford Reach is the fall chinook salmon. This assessment reviews the status of fall chinook salmon in the flowing midColumbia River and evaluates the effect of potential modifications in the Hanford Reach.

\subsection{FALL CHINOOK SALMON AT HANFORD}

Chinook salmon from the Columbia River Basin once comprised the largest and most important spawning population of chinook salmon in the world (Ricker 1959). Population levels of anadromous salmonids above McNary Dam have been greatly reduced. Fall chinook that spawn at Hanford contribute substantially to the surviving runs of anadromous fish in the Columbia River Basin. The Hanford population is important in many ways:

- The fish are "upriver brights," a race low in abundance elsewhere in the Columbia River system.

- Future increases in abundance of chinook salmon above Priest Rapids Dam are limited by lack of mainstream spawning areas, modification of rearing areas due to stream fluctuations, and high juvenile mortality rate at dams.

- Management agencies now trap most fall chinook salmon moving upriver at the Priest Rapids fish ladder for hatchery rearing programs.

- Enhancement programs by the State of Washington for fall chinook salmon in the Columbia River and its tributaries above Priest Rapids Dam are now reduced.

- Federal hatcheries above Hanford now concentrate on production of spring chinook salmon.

Habitat destruction in the Columbia River ecosystem has made operation of an extensive hatchery program necessary. Historically, the Federal government has assumed responsibility for supporting salmonid production facilities on the Columbia River as mitigation for losses from hydroelectric projects. Future 
hatcheries will likely be funded by electric-rate-payers through the Bonneville Power Administration. However, hatchery programs are costly, often plagued by low returns, and may provide only for minimal sustenance of the managed stocks.

The role of salmonid hatcheries on the Columbia River has been to substitute artificial production for natural production. The substitute fish may not be the same kind genetically as those lost (Cleaver 1977), and their quality may be less than wild fish. Experimental studies indicate that the character of wild salmonid stocks will function to increase their probability for survival. These attributes are controlled largely by genetic factors, the frequencies of which can be modified in a single generation by the artificial environment of hatcheries (McIntyre and Reisenbichler 1977). Many resource managers in the Pacific Northwest believe that maintaining genetic pools in populations that spawn naturally is a top priority (Bjornn 1977; Reisenbichler and McIntyre 1977; Salo and Sober 1977).

Fall chinook salmon spawn naturally in the Hanford Reach. But they are not true "wild fish," if defined as "members of a naturally produced and maintained population existing in a natural setting," because hatchery releases supplement natural production.

The fall chinook salmon population in the Hanford Reach today represents a mixed gene pool (Utter et al. 1982; also according to F. M. Utter, NMFS, Seattle, Washington, 1984). There are several possible reasons. For example, the run originated from misplaced stocks during construction of dams on the mid-Columbia River; the Priest Rapids hatchery has used eggs taken from downriver stocks and from intercepted upriver stocks as well as from Priest Rapids stocks; and large numbers of juveniles reared at other hatchery facilities have been released at Hanford. Massive releases from other sources, as practiced today with "Bonneville brights," will prevent the genetic makeup of fall chinook salmon in the Hanford Reach from stabilizing. While annual introductions of hatchery fish may have commercial (and political) value, development of a "wild fish" (sensu stricto) population is prevented.

The loss of spawning areas in the mid-Columbia River from dam construction, followed by elimination of many distinct breeding stocks, shows the need to preserve remaining spawning habitat and to maintain stock integrity. That 
the Hanford Reach has become a major spawning area for fall chinook salmon reflects the innate adaptability of the species in the face of heavy exploitation and habitat changes.

\subsection{EFFECTS ON THE HANFORD REACH}

An assessment of actual (occurring now) or potential (may occur in the future) activities on salmonid resources of the Hanford Reach can be made on the basis of the discussion in Section 4. Major effects are associated with changes that might occur in the future, particularly effects that alter or degrade the riverine environment (Figure 5.1).

Construction of a dam above Richland that would inundate the Hanford Reach, and dredging and commercial navigation in the Hanford Reach, have

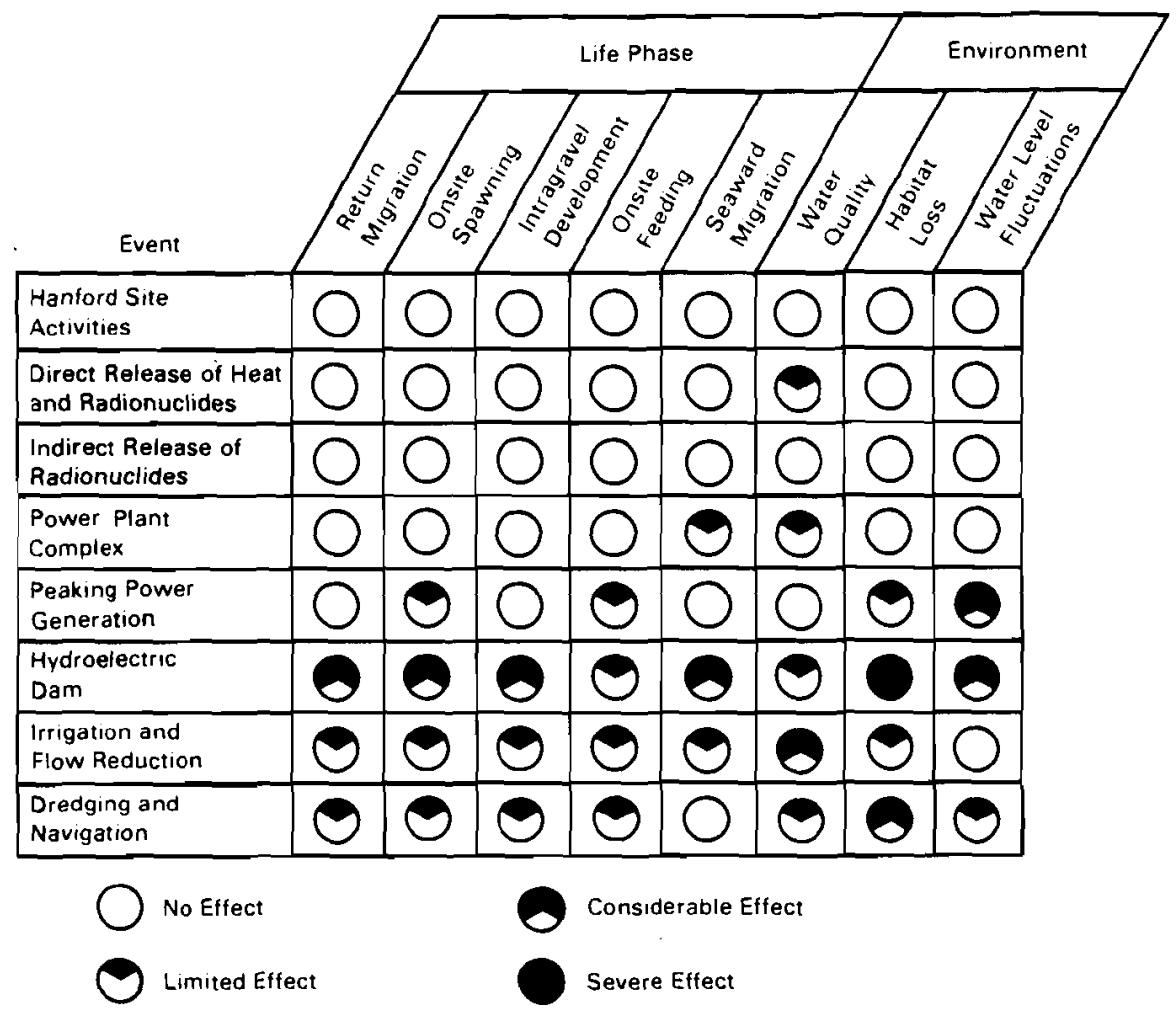

FIGURE 5.1. Assessment of Effects from Present or Potential Activities on Salmonid Resources of the Hanford Reach, Based on Life Cycle Phase and Environment 
potential to adversely impact anadromous salmonids. Implementation of the projects may be precluded by existing environmental statutes.

The maintenance of adequate instream flows in the Hanford Reach is also crucial for survival of anadromous salmonid runs. Reduced flows often intensify potential adverse effects from other instream uses, for example, the use of a stream as a diluent for waste heat, cooling tower blowdown, low-level radioactivity, and waste water from agricultural, domestic, municipal, and industrial sources.

Water quality is often a function of stream flow. Low flows often mean impaired water quality, and can shift an environmental stress, or combination of stresses, from acceptable to unacceptable. Over the long term, the chemical characteristics of Columbia River water must remain unimpaired to protect salmonids and other aquatic resources of the Hanford Reach. Future growth and development in the Columbia Basin, and strong competition for a finite water supply, will compound the problem of maintaining water quality and instream flows that provide adequate protection.

In 1983 and 1984, runs of adult fall chinook salmon, sockeye salmon, and steelhead over McNary Dam showed impressive increases. These increases may reflect the success of recent fishery management policies, particularly success in reducing mortality of smolts at dams during outmigration. Any policy that effectively increases the ratio of returns per parent spawner will also increase the need to maintain the Hanford Reach as a natural spawning area. Given the present precarious status of salmonid runs in the Columbia River Basin, enhancement, of naturally spawning populations must receive high priority among resource managers. 


\section{REFERENCES}

Allen, K. 0., and J. W. Hardy. 1980. Impacts of Navigational Dredging on Fish and Wildlife: A Literature Review. FWS/0BS-80/07, U.S. Fish and Wildiffe Service, Biological Services Program, Washington, D.C. 81 pp.

Allen, R. L. 1977. "Status of the Upper Columbia River Salmon and Steelhead Runs." In Columbia River Salmon and Steelhead, E. Schwiebert (ed.), p. 2330. Spec. Publ. No. 10, American Fisheries Society, Bethesda, Maryland.

Allen, R. L., and T. K. Meekin. 1973. An Evaluation of the Priest Rapids Chinook Salmon Spawning Channel, 1963-1971. Tech. Rept. No. 11, Washington Department of Fisheries, 01ympia, Washington. $52 \mathrm{pp}$.

Allen, R. L., and T. K. Meekin. 1980. Columbia River Sockeye Salmon Study, 1971-1974. Prog. Rept. No. 120, Washington Department of Fisheries, 01ympia, Washington. $75 \mathrm{pp}$.

Armacost, L. V. 1979. "Lower Snake River Fish and Wildlife Compensation." In The Mitigation Symposium: A National Workshop on Mitigating Losses of Fish and Wildlife Habitats, pp. 408-413. Gen. Tech. Rept. RM-65, U.S. Dept. of Agriculture, Fort Collins, Colorado.

Banks, J. W. 1969. "A Review of the Literature on the Upstream Migration of Adult Salmonids." J. Fish. Biol. 1:85-136.

Bauersfeld, K. 1978. The Effect of Daily Flow Fluctuations on Spawning Fall Chinook in the Columbia River. Tech. Rept. No. 38, Washington Department of Fisheries, Olympia, Washington. 32 pp.

Raxter, R. M. 1977. "Environmental Effects of Dams and Impoundments." Annu. Rev. Ecol. Syst. 8:255-283.

Baxter, R. M., and P. Claude. 1980. "Environmental Effects of Dams and Impoundments in Canada: Experience and Prospects." Can. Bull. Fish. Aquatic Sci. No. 205, Ottawa. $34 \mathrm{pp}$.

Bayha, K., and C. Koski. 1974. Anatomy of a River. An Evaluation of Water Requirements for the Hell's Canyon Reach of the Snake River. Pacific Northwest River Basins Commission, Vancouver, Washington. 203 pp.

Beak Consultants, Inc. 1980. Preoperational Environmental Monitoring Studies Near WNP 1,2, and 4, August 1978 Through March 1980. WPPSS Columbia River Ecology Studies, Vol. 7. Beak Consultants, Inc., Portland, Oregon.

Becker, C. D. 1973a. "Columbia River Thermal Effects Study: Reactor Effluent Problems." J. Water Pollut. Control Fed. 45:850-869. 
Becker, C. D. 1973b. "Food and Growth Parameters of Juvenile Chinook Salmon, Oncorhynchus tshawytscha, in Central Columbia River." Fish. Bu11. 71:387400.

Becker, C. D., D. H. Fickeisen, and J. C. Montgomery. 1981. Assessment of Impacts from Water Level Fluctuations on Fish in the Hanford Reach, CoTumbia River. PNL-3813, Pacific Northwest Laboratory, Richland, Washington. 53 pp.

Becker, C. D., and M. P. Fujihara. 1978. "The Bacterial Pathogen Flexibacter Columnaris and Its Epizootiology Among Columbia River Fish. A Review and Synthesis." Monograph No. 2, American Fisheries Society, Washington, D.C. $92 \mathrm{pp}$.

Bel1, M. C. 1973. Fisheries Handbook of Engineering Requirements and Biological Criteria. Fisheries-Engineering Research Program, U.S. Army Corps of Engineers, North Pacific Division, Portland, Oregon.

Bell, M. C., Z. E. Parkhurst, R. G. Porter, and M. Stevens. 1976. Effects of Power Peaking on Survival of Juvenile Fish at Lower Columbia and Snake River Dams. Contract No. DACW57-75-C-0173, U.S. Army Corps of Engineers, North Pacific Division, Portland, Oregon.

Bentley, W. W., and H. L. Raymond. 1976. "Delayed Migrations of Yearling Chinook Salmon Since Completion of Lower Monumental and Little Goose Dams on the Snake River." Trans. Am. Fish. Soc. 105:422-424.

Bjornn, T. C. 1977. "Wild Fish Production and Management." In Columbia River Salmon and Steelhead, E. Schwiebert (ed.), pp. 65-71. Spec. Public. No. 10, American Fisheries Society, Bethesda, Maryland.

Brockson, R. W., M. Fraser, and S. G. Hildebrand. 1982. "The Effects of Selected Hydraulic Structures on Fisheries and Limnology." CRC Crit. Rev. Environ. Control 12:69-89.

Brown, L. R., and P. B. Moyle. 1981. "The Impact of Squawfish on Salmonid Populations: A Review." N. Am. J. Fish. Mgt. 1:104-111.

Chapman, D., J. M. Van Hyning, and D. H. McKenzie. 1982. Alternative Approaches to Base Run and Compensation Goals for Columbia River SaTmon and Steelhead Resources. Prepared for Chelan County, Grant County, and Douglas County Public Utility Districts by Battelle, Pacific Northwest Laboratories, Richland, Washington.

Chapman, D., D. Weitkamp, T. Welsh, and E. Gullekson. 1981. Vernita Bar Spawning Survey 1979-1980. Doc. 81-0115-004F, Pubi ic Utility District No. 2 of Grant County, Ephrata, Washington. $67 \mathrm{pp}$. 
Chapman, D. W., D. E. Weitkamp, T. L. Welsh, and T. H. Schadt. 1983. Effects of Minimum Flow Regimes on Fall Chinook Salmon Spawning at Vernita Bar 19781982. Report to Grant County Public Utility District No. 2, Doc. No. 83-0715-008D, prepared by Don Chapman Consultants, Inc., McCa11, Idaho, and Parametrix Inc., Bellevue, Washington. $123 \mathrm{pp}$.

Cleaver, R. F. 1977. "Role of Hatcheries in the Management of Columbia River Salmon." In Columbia River Salmon and Steelhead, E. Schwiebert (ed.), pp. 89-92. Spec. Publ. No. 10, American Fisheries Society, Bethesda, Maryland.

Collins, G. B., W. J. Ebel, G. E. Monan, H. L. Raymond, and G. K. Tanonaka. 1975. The Snake River Salmon and Steelhead Crisis. Processed Report, NMFS, Northwest Fisheries Center, Seattle, washington. $30 \mathrm{pp}$.

Collins, G. B., J. R. Gauley, and C. H. Elling. 1962. "Ability of Salmonids to Ascend Fishways." Trans. Am. Fish. Soc. 91:1-7.

Columbia River Water Management Group (CRWMG). 1982. 1981 Annual Report, Committee on Fisheries Operations. CRWMG, Portland, Oregon.

Coutant, C. C. 1973. Behavior of U1trasonic Tagged Chinook Salmon and Steelhead Trout Migrating Past Hanford Thermal Discharges (1967). BNWL-1530, Pacific Northwest Laboratory, Richland, Washington. $14 \mathrm{pp}$.

Cramer, F. K., and R. C. 01 igher. 1964. "Passing Fish Through Hydraulic Turbines." Trans. Am. Fish. Soc. 93:243-259.

Cushing, C. E., D. G. Watson, A. J. Scott, and J. M. Gurtisen. 1981. "necrease of Radionuclides in Columbia River Biota Following Closure of Hanford Reactors." Health Phys. 41:59-67.

Dauble, D. D., R. H. Gray, and T. L. Page. 1980. "Importance of Insects and Zooplankton in the Diet of 0-Age Chinook Salmon (Oncorhynchus tshawytscha) in the Central Columbia River." Northwest Sci. 54: 253-258.

Dauble, D. D., and T. L. Page. 1984. Fish Distribution Studies Near N Reactor, Summer 1983. UNI-2754, prepared for UNC NucTear Industries by Pacific Northwest Laboratory, Richland, Washington. 54. pp.

Dewaard, B. 1981. Reproduction and Ecology of Canada Geese on the Hanford Reservation, 1953-1980. Special Report, Environmental Sciences Department, Pacific Northwest Laboratory, Richland, Washington. $87 \mathrm{pp}$.

Ebe1, W. J. 1969. "Supersaturation of Nitrogen in the Columbia River and its Effects on Salmon and Steelhead Trout." Fish. Bull. 68:1-11.

Ebel, W. J. 1977. "Major Passage Problems." In Columbia River Salmon and Steelhead, E. Schwiebert (ed.), pp. 33-39. Spec. Publ. No. 10, American Fisheries Society, Bethesda, Maryland. 
Ebel, W. J., H. L. Raymond, G. E. Monan, W. E. Farr, and G. K. Tanonaka. 1975. Effects of Atmospheric Gas Supersaturation Caused by Dams on Salmon and Steelhead Trout of the Snake and Columbia Rivers. Report, National Marine Fisheries Service, Seattle, Washington. $75 \mathrm{pp}$.

Ecker, R. M., R. G. Parkhurst, F. L. Thompson, and G. Whelan. 1983. N Reactor Thermal Plume Characterization During Pu-Only Mode of Operation. UNI-2618, prepared for United Nuclear Industries by Pacific Northwest Laboratory, Richland, Washington. 125(+) pp.

Eddy, P. A., L. S. Prater, and J. R. Reiger. 1983. Ground-Water Surveillance at the Hanford Site for CY-1982. PNL-4659, Pacific Northwest Laboratory, Richland, Washington. 39(+) pp.

Faurot, D. 1979. The Mid-Columbia Juvenile Salmonid Outmigration, 1977. Report for Chelan, Douglas and Grant County Public Utility Districts of Washington and for the National Marine Fisheries Service, Seattle, Washington. $20 \mathrm{pp}$.

Fickeisen, D. H., D. D. Dauble, D. A. Neitzel, W. H. Rickard, R. L. Skaggs, and J. L. Warren. 1980. Aquatic and Riparian Resource Study of the Hanford Reach, Columbia River, Washington. Prepared for U.S. Army Corps of Engineers, Seattle District, by Battelle, Pacific Northwest Laboratories, Richland, Washington.

Foerster, R. E. 1968. "The Sockeye Salmon Oncorhynchus nerka." Bul1. 162, Fish. Res. Board Can., Ottawa. 422 pp.

Foster, R. F. 1972. "The History of Hanford and Its Contribution of Radionuclides to the Columbia River." In The Columbia River Estuary and Adjacent Ocean Waters, Bioenvironmental Studies, A. T. Pruter and D. L. Alverson (eds.), pp. 3-18. University of Washington Press, Seattle, Washington.

Foster, R. F., R. L. Junkins, and C. E. Linderoth. 1961. "Waste Control at the Hanford Plutonium Production Plant." J. Water Pollut. Control Fed. $33: 511-529$.

Fredd, L. C. 1966. Analysis of Differences in Fish Counts at Columbia River Dams, 1957-1965. DA-35-026-CIVENG-65-44, Fish Commission of Oregon, PortTand, Oregon. $50 \mathrm{pp}$.

French, R. R., and R. J. Wahle. 1966. "Studies of Loss and Delay of Salmon Passing Rock Island Dam, Columbia River, 1954-1956." Fish. Bull. 65:339-368.

Fujihara, M. P., and F. P. Hungate. 1971. "Chondrococcus columnaris Disease of Fishes: Influence of Columbia River Fish Ladders." J. Fish. Res. Board Can. 28:533-536. 
Fulton, L. A. 1968. "Spawning Areas and Abundance of Chinook Salmon (Oncorhynchus tshawytscha) in the Columbia River Basin--Past and Present." Spec. Sci. Rept.--Fish. No. 571, U.S. Fish and Wildlife Service, Washington, D.C. $26 \mathrm{pp}$.

Fulton, L. A. 1970. "Spawning Areas and Abundance of Steelhead Trout and Coho, Sockeye, and Chum Salmon in the Columbia River Basin--Past and Present." Spec. Sci. Rept--Fish. No. 618, National Marine Fisheries Service, Washington, D.C. 37 pp.

Geen, G. H. 1974. "Effects of Hydroelectric Development in Western Canada on Aquatic Ecosystems." J.Fish. Res. Board Can. 31:913-927.

Gray, G. A., G. M. Sonnevil, H. C. Hansel, C. W. Huntington, and D. E. Palmer. 1984. Feeding Activity, Rate of Consumption, Daily Ration and Prey Selection of Major Predators in the John Day Pool. Annual Report 1982, prepared for BonneviTle Power Administration by U.S. Fish and Wildlife Service, Cook, Washington. $81 \mathrm{pp}$.

Gray, R. H., and D. D. Dauble. 1977. "Checklist and Relative Abundance of Fish Species from the Hanford Reach, Columbia River." Northwest Sci. $51: 208-215$.

Gray, R. H., and T. L. Page. 1977. Aquatic Ecological Studies Near WNP 1, 2 and 4, September 1975 Through March 1976. WPPSS Columbia River Ecology Studies, Vol. 3. Prepared for Washington Public Power Supply System under Contract No. 2311201335 with United Engineers and Constructors by Battelle, Pacific Northwest Laboratories, Richland, Washington.

Gray, R. H., and T. L. Page. 1978. Aguatic Ecological Studies Near WNP 1, 2 and 4, March Through December 1976. WPPSS Columbia River Ecology Studies, Vol. 4. Prepared for Washington Public Power Supply System under Contract No. 2311201335 with United Engineers and Constructors by Battelle, Pacific Northwest Laboratories, Richland, Washington.

Gray, R. H., and T. L. Page. 1979a. Aguatic Ecological Studies Near WNP 1, 2 and 4, January Through December 1977. WPPSS Columbia River Ecology Studies, Vo1. 5. Prepared for Washington Public Power Supply System under Contract No. 2311203104 by Battelle, Pacific Northwest Laboratories, Richland, Washington.

Gray, R. H., and T. L. Page. 1979b. Aquatic Ecological Studies Near WNP 1, 2 and 4, January Through August 1978. WPPSS Columbia River Ecology Studies, Vol. 6. Prepared for Washington Public Power Supply System under Contract No. 2311203104 by Battelle, Pacific Northwest Laboratories, Richland, Washington.

Gray, R. H., T. L. Page, and E. G. Wolf. 1976. Aquatic Ecological Studies Conducted Near WNP 1, 2 and 4, September 1974 Through September 1975. WPPSS Columbia River Ecology Studies, Vol. 2. Prepared for Washington Public Power Supply System under Contract No. 2311201335 with United Engineers and Constructors by Battelle, Pacific Northwest Laboratories, Richland, Washington. 
Greager, E. M. 1983. UNC Environmental Surveillance Report for the 100 Areas--FY 1983. UNI -2640, prepared for U.S. Department of Energy by UNC Nuclear Industries, Richland, Washington. $38 \mathrm{pp}$.

Greenwood, D. R., G. L. Kingsbury, and J. G. Cleland. 1979. A Handbook of Key Federal Regulations and Criteria for Multimedia EnvironmentaT Control. EPA600/7-79-175, U.S. Environmental Protection Agency. Available from National Technical Information Service, Springfield, Virginia. 271 pp.

Groves, A. B., G. B. Collins, and P. S. Trefethen. 1968. "Roles of 01 faction and Vision in the Choice of Spawning Site by Homing Adult Chinook Salmon (Oncorhynchus tshawytscha)." J. Fish. Res. Board Can. 25:867-876.

Haber, D. F., B. Moore, and W. Hicks. 1978. A Review of the Impacts of Fluctuating Flows on the Lower Clearwater River and Recominendations for Future Studies. Contract No. DACW68-76-M-2586, Idaho Water Resources Research Institute, University of Idaho, Moscow, Idaho. 35 pp.

Harty, H. 1979. The Effects of Ben Frankl in Dam on the Hanford Site. PNL2821, Pacific Northwest Laboratory, Richland, Washington. $215 \mathrm{pp}$.

Harty, H., and W. J. Dowis. 1983. Electric Power Transmission for a Hanford Nuclear Energy Center (HNEC). PNL-4685, Pacific Northwest Laboratory, RichTand, Washington.

Haushild, W. L., G. R. Dempster, Jr., and H. H. Stevens, Jr. 1975. "Distribution of Radionuclides in the Columbia River Streambed, Hanford Reservation to Longview, Washington." Geological Survey Prof. Paper, 433-0, U.S. Government Printing Office, Washington, D.C. $27 \mathrm{pp}$.

Hemmingway, R. 1983. "The Northwest Power Planning Counci1: Its Origins and Future Role." Environ. Law 13:673-698.

Hildebrand, S. G., R. R. Turner, L. D. Wright, A. T. Szluha, B. Tschantz, and S. Tam. 1980. Analysis of Environmental Issues Related to Small-Scale Hydroelectric Development. III. Water Level FTuctuation. ORNL-TM-7453, Pub1. No. 1591, Environmental Sciences Division, Oak Ridge National Laboratory, Oak Ridge, Tennessee. $78(+)$ pp.

Horner, N., and T. C. Bjornn. 1979. Status of Upper Columbia River Fall Chinook Salmon (Excluding Snake River Populations). Prepared for U.S. Fish and WiTdife Service by Idaho Cooperative Fishery Research Unit, University of Idaho, Moscow, Idaho. $45 \mathrm{pp}$.

Horner, N., and T. C. Bjornn. 1981a. Status of Upper Columbia and Snake River Coho Salmon in Relation to the Endangered Species Act. Prepared for U.S. Fish and Wildlife Service by Idaho Cooperative Fishery Research Unit, University of Idaho, Moscow, Idaho. $45 \mathrm{pp}$. 
Horner, N., and T. C. Bjornn. 1981b. Status of Upper Columbia and Snake River Spring Chinook Salmon in Relation to the Endangered Species Act. Prepared for T.S. Fish and Wildlife Service by Idaho Cooperative Fishery Research Unit, University of Idaho, Moscow, Idaho. $63 \mathrm{pp}$.

Horner, N., and T. C. Bjornn. 1981C. Status of Upper Columbia and Snake River Summer Chinook Salmon in Relation to the Endangered Species Act. Prepared for U.S. Fish and Wildlife Service by Idaho Cooperative Fishery Research Unit, University of Idaho, Moscow, Idaho. $58 \mathrm{pp}$.

Hovland, G. B., R. S. Kindley, M. T. Rudnicki, M. B. Dell, and J. D. Pock. 1982. The Mid-Columbia Juvenile Salmonid Outmigration in 1981 at Priest Rapids Dam. PubTic Utility District No. 2 of Grant County, Ephrata, Washington. $27 \mathrm{pp}$.

Jaske, R. T. and J. B. Goebel. 1967. "Effects of Dam Construction on Temperatures of Columbia River." J. Am. Water Works Assoc. 59:935-942.

Jaske, R. T., and M. 0. Synoground. 1970. Effect of Hanford Plant Operations on the Temperature of the Columbia River 1964 to Present. BNWL-1345, Pacific Northwest Laboratory, Richland, Washington.

Kaczynski, V. W., and D. W. Moos. 1979. "Strategies for Mid-Columbia Fish Production." In The Mitigation Symposium: A National Workshop on Mitigating Losses of Fish and Wildlife Habitats, pp. 289-295. Gen. Tech. Rept. RM-65, U.S. Dept. of Agriculture, Fort Collins, Colorado.

Law, A. G., and R. M. Allen. 1984: Results of the Separations Area GroundWater Monitoring Network for 1983. RH0-RE-SR-84-24P. Prepared for U.S. Department of Energy by Rockwell Hanford Operations, Richland, Washington.

Lehman, B., and G. J. Paulik. 1966. "Spill-Pattern Manipulation to Guide Migrant Salmon Ijpstream." Trans. Am. Fish. Soc. 95:397-407.

Mahnken, C., E. Prentice, W. Waknitz, G. Monan, C. Sims, and J. Williams. 1982. "The application of Recent Smoltification Research to Public Hatchery Releases: An Assessment of Size/Time Requirements for Columbia River Hatchery Coho Salmon (Oncorhynchus kisutch)." Aquaculture 28:251-268.

Mains, E. M., and J. M. Smith. 1964. "The Distribution, Size, Time and Current Preferences of Seaward Migrant Chinook Salmon in the Columbia and Snake Rivers." Washington Department of Fisheries, Fish. Res. Papers 2:5-43.

Major, R. L., and J. L. Mighe11. 1969. "Egg-To-Migrant Survival of Spring Chinook Salmon (Oncorhynchus tshawytscha) in the Yakima River, Washington." Fish. Bull. 67:347-359.

McIntyre, J. D., and R. R. Reisenbichler. 1977. "An Effect of Interbreeding Hatchery and Wild Anadromous Salmonids." In Columbia River Salmon and Steelhead, E. Schwiebert (ed.), pp. 93-94. Spec. Publ. No. 10, American Fisheries Society, Bethesda, Maryland. 
Meekin, T. K., and R. L. Allen. 1974. Nitrogen Saturation Levels in the MidColumbia River, 1965-1971. Tech. Rept. No. 12, Washington Department of Fisheries, Olympia, Washington.

Monan, G. E. and K. L. Liscom. 1976. Radio-Tracking Studies of Summer Chinook and Steelhead Trout at and Between Bonneville and The Dalles Dam, 1975. Contr. No. DACW 57-75-F-0548, Progress Rept. to U.S. Army Corps of Engineers, Portland, Oregon. $51 \mathrm{pp}$.

Mullan, J. W. 1982. Administrative Report, Spring Chinook Salmon Program, Leavenworth, Entiat and Winthrop Hatcheries. U.S. Fish and Wildlife Service, Fisheries Assistance Office, Leavenworth, Washington. 20 pp.

Mullan, J. W. 1984a. Overview of Artificial and Natural Propagation of Coho Salmon (Oncorhynchus kisutch) in the Mid-Columbia River. U.S. Fish and WiTdTife Service, Fisheries Assistance Office, Leavenworth, Washington. 37 pp.

Mullan, J. W. 1984b. Determinants of Sockeye Salmon Abundance in the Columbia River. U.S. Fish and Wildife Service, Fisheries Assistance Office, Leavenworth, Washington. $159 \mathrm{pp}$.

Neitzel, D. A., T. L. Page, and R. W. Hanf, Jr. 1982a. "Mid-Columbia River Microflora." J. Freshwater Ecol. 1:495-505.

Neitzel, D. A., T. L. Page, and R. W. Hanf, Jr. 1982b. "Mid-Columbia River Zooplankton." Northwest Sci. 52:112-118.

Neitze1, D. A., T. L. Page, and D. D. Dauble. 1982c. "Once-Through Cooling on the Columbia River - The Best Available Technology?" Impact Assess. Rev. $3: 43-58$.

Neitzel, D. A., C. D. Becker, C. S. Abernethy, D. W. Carlile, and E. W. Lusty. 1984. Laboratory Simulations of Chinook Salmon Redd Dewatering: An Assessment of Potential Impacts at Vernita Bar. Prepared for Public Utility District No. 2 of Grant County, Ephrata, Washington, by Battelle, Pacific Northwest Laboratories, Richland, Washington.

Nelson, J. L., and W. L. Haushild. 1970. "Accumulation of Radionuclides in Bed Sediments of the Columbia River Between the Hanford Reactors and McNary Dam." Water Resour. Res. 6:130-137.

Netboy, A. 1974. The Salmon, Their Fight For Survival. Houghton Miff1in Co., Boston, Massachusetts. $613 \mathrm{pp}$.

Northwest Power Planning Council (NPPC). 1982. Columbia River Basin Fish and Wildlife Program. Adopted Pursuant to Section $4(\mathrm{~h})$ of the Pacific Northwest Electric Power Planning and Conservation Act of 1980 (P.L. 96-501). NPPC, Portland, Oregon. 
01 son, F. W. 1981. The Migration and Behavioral Characteristics of Juvenile Salmonids at Priest Rapids Dam, Spring 1980. Report for Public Utility Districts of Grant, Douglas, and Chelan Counties by CH2M Hill, Bellevue, Washington. $49 \mathrm{pp}$.

Oregon Department of Fish and Wildlife, and Washington Department of Fisheries (ODFW and WDF). 1983. Columbia River Fish Runs and Fisheries 1960-1981. Oregon Department of Fish and Wildtife, Portland, Oregon. 83 pp.

Page, T. L., D. D. Dauble, and D. A. Neitzel. 1982. Columbia River Aquatic Ecologial Studies Near the Skagit/Hanford Nuclear Project: Final Report. Prepared for Northwest Energy Services Company by Battelle, Pacific Northwest Laboratories, Richland, Washington. $82 \mathrm{pp}$.

Page, T. L., R. H. Gray, and E. G. Wolf. 1976. Final Report on Aquatic Ecological Studies Conducted at the Hanford Generating Project 1973-1974. WPPSS Columbia River Ecologial Studies, Vol. 1. Prepared for Washington State Public Power Supply System under Contract No. 2311201335 with United Engineers and Constructors by Battelle, Pacific Northwest Laboratories, Richland, Washington.

Page, T. L., R. H. Gray, and D. A. Neitzel. 1977. Fish Impingement and Screen Passage Studies at Hanford Generating Project. BN-SA-775, Battelle, Pacific Northwest Laboratories, Richland, Washington. 22 pp.

Page, T. L., D. A. Neitzel, and R. H. Gray. 1978. "Comparative Fish Impingement at Two Adjacent Water. Intakes on the Mid-Columbia River." In 4th National Workshop on Impingement and Entrainment, L. D. iensen (ed.), pp. 257-266. E. A. Communications, MelvilTe, New York.

Parametrix, Inc. 1984. 1983 Gatewe11 Sampling Wanapum and Priest Rapids Dams. Doc. No. 84-0106-001D, prepared for Public Utility District No. 4 of Grant County, Ephrata, Washington by Parametrix, Inc., Bellevue, Washington.

Parametrix, Inc., D. Chapman, and T. Helsh. 1979. Vernita Bar Spawning Survey 1978-79. Doc 79-1221-36F, prepared for Public Utility District No. 2 of Grant County, Ephrata, Washington. 45 pp.

Park, D. L. 1969. "Seasonal Changes in Downstream Migration of Age-Group 0 Chinook Salmon in the Ipper Columbia River." Trans. Am. Fish. Soc. 98:315317.

Park, D. L., and W. W. Bentley. 1968. A Summary of the 1967 Outmigration of Juvenile Salmonids in the Columbia Basin: Progress Report. Biological Laboratory, U.S. Bureau Commercial Fisheries, Seattle, Washington.

Price, K. R., J. M. V. Carlile, R. L. Dirkes, and M. S. Trevathan. 1984. Environmental Surveillance at Hanford for CY 1983. PNL-5038, Pacific Northwest Laboratory, Richland, Washington. $50 \mathrm{pp}$. 
Puget Sound Power and Light Company (Puget Power). 1982. Skagit/Hanford Nuclear Project, Application for Site Certification/Environmental Report, Vol. 1. U.S. Department of Energy, Richland Operations Office, Richland, Washington.

Puget Sound Power and Light Company (Puget Power) et al. 1982. Draft Environmental Statement Related to the Construction of Skagit/Hanford Nuclear Project, Units 1 and 2, Docket Nos. STN 50-522 and STN 50-523. NUREG-0894, U.S. Nuclear Regulatory Commission, Washington, D.C., and Washington State Energy Facility Site Evaluation Council, Olympia, Washington.

Raemhi1d, G. A., S. Kueh1, and A. Murphy. 1984. Hydroacoustic Assessment of Downstream Migrating Juvenile Salmonids at Priest Rapids Dam in Summer 1983. Prepared for Grant County Public Itility Distric No. 2, Ephrata, Washington, and Department of Energy, Bonneville Power Administration, Portland, Oregon by Biosonics, Inc., Seattle, Washington.

Raymond, H. L. 1968. "Migration Rates of Yearling Chinook Salmon in Relation to Flows and Impoundments in the Columbia and Snake Rivers." Trans. Am. Fish. Soc. 97:356-359.

Raymond, H. L. 1969. "Effect of John Day Reservoir on the Migration Rate of Juvenile Chinook Salmon in the Columbia River." Trans. Am. Fish. Soc. 98:513-514.

Raymond, H. L. 1979. "Effects of Dams and Impoundments on Migrations of Juvenile Salmon and Steelhead from the Snake River, 1966 to 1975." Trans. Am. Fish. Soc. 108:505-529.

Reisenbichler, R. R., and J. D. McIntyre. 1977. "Genetic Differences in Growth and Survival of Juvenile Hatchery and Wild Steelhead Trout, Salmo gairdneri." J. Fish. Res. Board Can. 34:123-128.

Rickard, W. H., W. C. Hanson, and R. E. Fitzner. 1982. "The Non-Fisheries Biological Resources of the Hanford Reach of the Columbia River." Northwest Sci. 56:62-75.

Ricker, W. E. 1959. Evidence for Environmental and Genetic Influence on Certain Characters Which Distinguish Stocks of the Pacific Salmons and Steelhead Trout. Report, Fish. Res. Board Can., Biological Station, Nanaimo, British Columbia. 103 pp.

Robeck, G. G., C. Henderson, and R. C. Palange. 1954. Water Quality Studies on the Columbia River. Report, U.S. Dept. Health, Education and Welfare, Cincinnati, Ohio. 99 pp.

Robertson, D. E., and J. J. Fix. 1977. Association of Hanford Origin Radionuclides with Columbia River Sediment. BNWL-2305, Pacific Northwest Laboratory, Richland, Washington. $36(+) \mathrm{pp}$. 
Salo, E. 0., and Q. J. Stober. 1977. "Man's Impact on the Columbia River Stocks of Salmon." In Assessing the Effects of Power-Plant-Induced Mortality on Fish Populations, W. Van WinkTe (ed.), pp. 36-45. Pergammon Press, New York.

Seufert, F. 1980. Wheels of Fortune. Oregon Historical Society, Portland, Oregon. $259 \mathrm{pp}$.

Simpson, P. W., J. R. Newman, M. A. Keirn, R. M. Matter, and P. A. Guthrie. 1982. Manual of Stream Channelization Impacts on Fish and Wildlife. FWS/OBS - 82/24, U.S. Fish and WildTife Service, Biological Services Program, Washington, D.C. $154 \mathrm{pp}$.

Sims, C. W., and D. R. Miller. 1976. Migrational Characteristics of Juvenile Salmonids in the Mid-Columbia River During 1976. Report for Chelan, Douglas, and Grant County Public Utility Districts of Washington and for the National Marine Fisheries Service, Seattle, Washington. $18 \mathrm{pp}$.

Smith, C. L. 1979. Salmon Fishers of the Columbia. Oregon State University Press, Corvallis, Oregon. $117 \mathrm{pp}$.

Smith, J. R. 1974. "Distribution of Seaward-Migrating Chinook Salmon and Steelhead Trout in the Snake River Above Lower Monumental Dam." Mar. Fish. Rev. 36:42-45.

Stober, Q. J., S. C. Crumley, D. E. Fast, E. S. Killebrew, R. Woodin, G. Engman, and G. Tutmark. 1982. Effects of Hydroelectric Discharge Fluctuations on Salmon and Steelhead in the Skagit River, Washington. FRI-UW-8218, prepared for Seattle Department of Lighting by the Fisheries Research Institute, University of Washington, Seattle. 202 pp.

Stone, W. A., J. M. Thorp, 0. P. Gifford, and D. J. Hoitink. 1983. Climatological Survey for the Hanford Area. PNL-4622, Pacific Northwest Laboratory, Richland, Washington.

Sula, M. J., J. M. V. Carlile, K. R. Price, and W. D. McCornack. 1983. Environmental Survey at Hanford for CY 1982. PNL-4657, Pacific Northwest Laboratory, Richland, Washington. $54 \mathrm{pp}$.

Sylvester, R. 0. 1959. "Water Quality Study of Wenatchee and Middle Columbia River Before Dam Construction." Spec. Sci. Rept.- Fish. No. 290. 116 pp.

Thompson, R. B. 1959. "Food of the Squawfish Ptychocheilus oregonensis (Richardson) of the Lower Columbia River." Fish. BuTl. 158:43-58.

Thompson, W. F. 1951. An Outline for Salmon Research in Alaska. Circular No. 18, Fisheries Research Institute, University of Washington, Seattle. 49 pp. 
Turbak, S. C., D. R. Reichle, and C. R. Shriner. 1981. Analys is of Environmental Issues Related to Small-Scale Hydroelectric Development: Fish Mortality Resulting From Turbine Passage. Pub1. 1597, Environmental Sciences Division, Oak Ridge National Laboratory, Oak Ridge, Tennessee.

U.S. Army Corps of Engineers (U.S. ACOE). 1969. Ben Franklin Lock, Dam and Reservoir, Vols. 1 and 2. U.S. ACOE, Seattle District, Seattle, Washington.

U.S. Army Corps of Engineers (U.S. ACOE). 1976a. Columbia River and Tributaries, Irrigation Depletions, Instream Flow Study. CRT 29, U.S. ACOE, Wa11a Walla District, Walla Walla, Washington.

U.S. Army Corps of Engineers (U.S. ACOE). 1976b. Columbia River and Tributaries, Irrigation Depletions/Instream Flow Study. U.S. ACOE, Walla Walla District, Walla Walla, Washington.

U.S. Army Corps of Engineers (U.S. ACOE). 1983. Annual Fish Passage Report 1982. Columbia River Projects, Snake River Projects, Oregon and Washington. U.S. ACOE, North Pacific Division, Portland, Oregon.

U.S. Department of Energy (U.S. DOE). 1982. 316(a) Demonstration for Test of $\mathrm{N}$ Reactor in Plutonium-Only Mode of Operation. U.S. DOE, Richland Operations Office, Richland, Washington.

U.S. Energy and Research Development Administration (U.S. ERDA). 1975. Final Environmental Statement, Waste Management Operations, Hanford Reservation, Richland, Washington. ERDA-1538 (2 Vols.). Available from National Technical Information Service, Springfield, Virginia.

U.S. Nuclear Regulatory Commission (U.S. NRC). 1975. Final Environmental Impact Statement Related to Construction of Washington Public Power Supply System Nuclear Projects 1 and 4, Docket Nos. 50-460 and 50-513. NUREG$75 / 012$, Office of Nuclear Reactor Regulation, Washington, D.C.

Utter, F. M., W. J. Ebel, G. M. Milner, and D. J. Teel. 1982. Population Structures of Fall Chinook Salmon, Oncorhynchus tshawytscha, of the MidColumbia and Snake Rivers. Processed Report No. 82-10, NWAFC, National Marine Fisheries Service, Seattle, Washington. 14 pp.

Van Hyning, J. M. 1973. "Factors Affecting the Abundance of Fall Chinook Salmon in the Columbia River." Res. Repts., Fish Commission of Oregon. $4: 1-87$.

Wahle, R. J., R. 0. Koski, and R. Z. Smith. 1979. "Contribution of 1960-1963 Brood Hatchery-Reared Sockeye Salmon, Oncorhynchus nerka, to the Columbia River Commercial Fishery." Fish. Bu11. 77:229-242.

Ward, J. V., and J. A. Stanford. 1979. The Ecology of Regulated Streams. Plenum Press, New York. 398 pp. 
Washington Public Power Supply System (WPPSS). 1977. WPPS Nuclear Project No. 2, Environmental Report, Operating License Stage, Docket No. 50-397. WPPSS, Richland, Washington.

Washington Public Power Supply System (WPPSS). 1978. Supplemental Information on the Hanford Generating Project in Support of a $316(a)$ Demonstration. WPPSS, Richland, Washington.

Washington State Department of Ecology (WSDOE). 1977. Washington State Water Quality Standards, Chapter 173-201. WSDOE, Olympia, Washington.

Washington State Department of Ecology (WSDOE). 1980. Surface Impoundment Inventory and Assessment Program in Washington State. DOE 80-5, WSDOE, Otympia, Washington. $46 \mathrm{pp}$.

Watson, D. G. 1970. Fall Chinook Salmon Spawning in the Columbia River near Hanford 1947-1969. BNWL-1515, Pacific Northwest Laboratory, Richland, Washington. $40 \mathrm{pp}$.

Watson, D. G. 1973. Estimate of Steelhead Trout Spawning in the Hanford Reach of the Columbia River. Prepared for U.S. Army Corps of Engineers by Bat telle, Pacific Northwest Laboratories, Richland, Washington. 30 pp.

Watson, D. G. 1976. Temporal and Spatial Fall Chinook Salmon Redd Distribution Near Hanford, 1962-1976. BNWL-2163, Pacific Northwest Laboratory, RichTand, Washington. $6 \mathrm{pp}$.

Weaver, C. R. 1963. "Influence of Water Velocity Upon Orientation and Performance of Adult Migrating Salmonids." Fish. Bu11. 63:87-121.

Wedemeyer, G. A., R. L. Saunders, and W. C. Clarke. 1980. "Environmental Factors Affecting Smoltification and Early Marine Survival of Anadromous Salmonids." Mar. Fish. Rev. (June):1-14.

Weitkamp, D., D. Chapman, T. Welsh, and T. Shadt. 1982. 1980 Vernita Bar Spawning Survey, Final Report. Doc. No. 82-0910-019F, Public Utility District No. 2 of Grant County, Ephrata, Washington. 68 pp.

Weitkamp, D. E., and M. Katz. 1980. "A Review of Dissolved Gas Supersaturation Literature." Trans. Am. Fish. Soc. 109:659-702.

Weitkamp, D. E., and D. M. McEntee. 1982. 1982 Gatewell Sampling, Wanapum and Priest Rapids Dams. Doc. No. 82-1124-26D1, prepared for Public Utility District No. 2 of Grant County by Parametrix, Inc., Bellevue, Washington. $37 \mathrm{pp}$.

Whelan, G., and C. A. Newbi11. 1983. Update of Columbia River Flow and Temperature Data Measured at Priest Rapids Dam and Vernita Bridge. PNL-4868, prepared for UNC Nuclear Industries, Inc. by Battelle, Pacific Northwest Laboratories, Richland, Washington. 34(+) pp. 
Whetten, J. T., J. C. Kelley, and L. G. Hanson. 1969. "Characteristics of Columbia River Sediment and Sediment Transport." J. Sediment. Petrology 39:1149-1166.

Wilbur, J. S., L. S. Prater, and P. A. Eddy. 1983. "Ground-Water Monitoring Programs at the Hanford Site, Washington State." In Proc. 4th DOE Environmental Protection Information Meeting, August 1983, pp. 489-506. Washington, D.C.

Wildung, R. E., R. C. Routson, and R. L. Schmidt. 1972. Seasonal Changes in Particle Size Distribution, Composition, and Strontium Exchange Capacity of Particulate Matter Suspended in the Columbia River. BNWL-1638, Pacific Northwest Laboratory, Richland, Washington. $26 \mathrm{pp}$.

Withler, J. L. 1966. "Variability in Life History Characteristics of Steelhead Trout, Salmo gairdneri, Along the Pacific Coast of North America." J. Fish. Res. Board Can. 23:365-393.

Wydowski, R. S., and R. R. Whitney. 1979. Inland Fishes of Washington. University of Washington Press, Seattle, Washington. $220 \mathrm{pp}$. 
DISTR IBUTION

No. of

Copies

OFFSITE

30 DOE - Technical Information Center

DOE Public Document Reading Room GA-142

Forrestal Building 1000 Independence Avenue S.W. Washington, DC 20585

R. L. Watters

Ecological Research Division, ER-75

Office of Health and

Environmental Research

Office of Energy Research

Washington, DC 20545

J. Dorigan

Ecological Research Division, ER-75

Office of Health and

Environmental Research

Office of Energy Research

Washington, DC 20545

D. Heyward Hamilton

Ecological Research Division, ER-75

Office of Health and

Environmental Research

Office of Energy Research

Washington, DC 20545

H. M. McCammon

Ecological Research Division, ER-75

Office of Health and

Environmental Research

Office of Energy Research

Washington, DC 20545
No. of

Copies

W. S. Osburn, Ur.

Ecological Research Division, ER-75

Office of Health and

Environmental Research

Office of Energy Research

Washington, DC 20545

S. E. Auerbach

Oak Ridge National Laboratory

P. 0. Box X

Oak Ridge, TN 37830

Milo C. Bell

University of Washington

College of Fisheries WA-10

Seattle, WA 98195

D. L. Beyer

Envirosphere Co. 10800 N.E. 8th St.

Bellevue, WA 98004

T. C. Bjornn, Leader

Idaho Cooperative Fish.

Research Unit

University of Idaho

Moscow, ID 83843

G. R. Bouck

Division of Fish and Wildlife

Bonneville Power Administration

P.0. Box 3621

Portland, OR 97208

E. L. Brannon

University of Washington

110 Fisheries Center

Seattle, WA 98195

D. W. Chapman

Chapman and Associates

P.0. Box 1362

McCall, ID 83638 
No. of

Copies

J. Chrisman

Northwest Power Planning Council

850 S.W. Broadway

Suite 1100

Portland, OR 97205

Columbia River Intertribal Fish Commission

2705 E. Burnside St., Suite 114

Portland, OR 97214

M. B. Dell

Public Utility District \#2, Grant County

P.0. Box 878, 30 C Street S.W.

Ephrata, WA 98823

W. J. Ebel

National Marine Fisheries Service

Northwest and Alaska Fisheries Center

2725 Montlake Blvd E.

Seattle, WA 98112

M. W. Erho

Douglas Co. Public Utility District

1151 N. Main St.

E. Wenatchee, WA 98801

D. R. Evans

National Marine Fisheries Service

847 N.E. 19th Avenue

Portland, OR 97208

J. Gearheard

Department of Game

600 N. Capital Way

Olympia, WA 98504
No. of

Copies

G. A. Gray

USFWS, National Fishery

Research Center

Willard Substation

Star Route

Cook, WA 98605

F. Hahn

Department of Ecology

MS PV-11

Olympia, WA 98504

T. F. Hakonson

Group LS-6

Los Alamos National Laboratory

P.0. Box 1663

Los Alamos, NM 87545

A Hausrath, President Idaho Environmental Council

P.0. Box 1708

Idaho Falls, ID 83401

D. R. Heinle

$\mathrm{CH}_{2} \mathrm{M} \mathrm{Hill}$

1500 114th Avenue S.E.

Bellevue, WA 98004

H. F. Horton

Department of Fisheries and Wildlife

Oregon State University

Corvallis, OR 97331

J. S. Isakson

Dames and More

P. 0. Box C-25901

Seattle, WA 98125

Russell Jim, Councilman

Attention: E. Reber

Yakima Indian Nation

P.0. Box 151

Toppenish, WA 98948 
No. of

Copies

M. Karr, Manager

Water Budget Center

2705 E. Burnside Street

Portland, OR 97214

J. W. Kincheloe

USFWS

1309 N.E. 13th St.

Vancouver, WA 98665

K. Kurko

Seattle City Light

Environmental Affairs Division 1015 3rd Avenue

Seattle, WA 98104

B. D. Leman

Chelan Co. Public Utility District

P. 0. Box 1231

Wenatchee, WA 98801

J. A. Lichatowich

Oregon Department of Fish and Wild ife

303 Extension $\mathrm{Ha} 11$

Oregon State University

Corvallis, OR 97331

W. M. McMonies, President Oregon Environmental Council 2321 S. W. Sherwood Dr.

Portland, OR 97201

E. P. Manary

Assistant Director, Salmon

Department of Fisheries

115 General Administration Building

Olympia, WA 98504

0. D. Markham

Radiological and Environmental Sciences Laboratory

P.0. Box 2108

Idaho Falls, ID 83401
No. of

Copies

B. S. Miller

Fisheries Research Institute

College of Fisheries

University of Washington

Seatt le, WA 998195

G. Milner

National Marine Fisheries

Service

Northwest Fisheries Center

2725 Montlake Blvd East

Seattle, WA 98112

D. W. Moos

State Department of Ecology

Mail Stop PV-11

Olympia, WA 98504

J. E. Mudge

Washington Public Power Supply System

Mail Drop 1020, P.0. Box 968

Richland, WA 99352

J. A. Mullan

USFWS, Leavenworth National

Fish Hatchery

Rt. 1, Box 123-A

Leavenworth, WA 98826

R. E. Nakatani

Fisheries Research Institute

College of Fisheries

University of Washington

Seattle, WA 98195

W. R. Nelson

USFWS, National Fishery

Research Center

Willard Substation

Star Route

Cook, WA 98605

T. J. Novotny

National Marine Fisheries

Service

2725 Mont lake Blvd. E.

Seattle, WA 98112 
No. of

Copies

J. R. Palensky

Northwest Power Planning

Council

850 S.W. Broadway

Suite 1100

Portland, OR 97205

D. L. Park

National Marine Fisheries

Service

Northwest and Alaska Fisheries

Center

2725 Montlake Blvd. E.

Seattle, WA 98112

G. B. Pauley

Washington Coop. Fish.

Research unit

School of Fisheries

University of Washington

Seattle, WA 98195

J. Pavletich, Executive Director

Trout Unlimited, NSSC

2100 Bay Avenue

Aberdeen, WA 98520

R. W. Phillips

U.S. Forest Service

P. 0. Box 3623

Portland, OR 97034

D. E. Phinney

Habitat Management

Department of Fisheries

115 General Administration

Building

01 ympia, WA 98504

W. S. Platts

U.S. Forest Service

316 E. Myrt le

Boise, ID 83702
No. of

Copies

H. L. Raymond

National Marine Fisheries

Service

Northwest and Alaska Fisheries

Center

2725 Montlake Blvd. E.

Seattle, WA 98112

D. W. Reiser

Bechtel Group, Inc.

Fifty Beale Street

P.0. Box 3965

San Francisco, CA 94119

M. J. Schneider

Northwest Power Planning Council

850 S.W. Broadway

Suite 1100

Portland, OR 97205

C. B. Schreck, Leader Oregon Cooperative Fish. Research Unit

Oregon State University

Corvallis, OR 97331

B. Shuey, President

Washington Environmental

Council, Inc.

1010 Fourth and Pike Building

Seattle, WA 98101

H. D. Smith

Department of Fisheries and Oceans

Pacific Biological Station

Nanaimo, B.C.

Canada V9R $5 \mathrm{~K} 6$

M. Smith, Director

Savannah River Ecology Laboratory

Drawer E

Aiken, SC 29801 
No. of

Copies

G. C. Sorenson

Washington Public Power Supply System

3000 George Washington Way

Richland, WA 99352

Q. J. Stober

Fisheries Research Institute

College of Fisheries

University of Washington

Seattle, WA 98195

A. Troppman, President

Washington State Sportsmen's Council

245 N. Garfield

Wenatchee, WA 98801

R. L. Tuck, Di rector

Fish and Wildlife Resource Mgt. P.0. Box 151

Toppenish, WA 98948

F. M. Utter

National Marine Fisheries Service

Northwest Fisheries Center

2725 Montlake Blvd East

Seattle, WA 98112

G. E. Wedemeyer

USFWS, National Fishery

Research Center

Building 204, Naval Station

Seattle, WA 98115

D. E. Weitkamp

Parametrix, Inc.

13020 Northup Way

Bellevue, WA 98004

T. L. Welsh

Box 159

McCal1, ID 83638
No. of

Copies

R. G. White, Leader

Montana Cooperative Fish. Research Unit

Biology Department

Montana State University

Bozeman, MT 59717

R. R. Whitney, Leader

Washington Cooperative Fish. Research Unit

College of Fisheries

University of Washington

Seattle, WA 98195

G. Winans

National Marine Fisheries

Service

Northwest Fisheries Center

2725 Montlake Blvd East

Seattle, WA 98112

R. M. Woodin

Department of Fisheries

Habitat Management

Rm 115 General Administration Building

01 ympia, WA 98504

A. Wright

Public Utility District \#2, Grant County

P.0. Box 878, 30 C. Street S.W. Ephrata, WA 93323

S. Wright

Division of Fisheries Management

Department of Game

600 N. Capitol Way

01 ympia, WA 98504

W. H. Young, Director

Oregon State Department of

Environmental Quality

1234 S.W. Morrison

Portland, OR 97205 
No. of

Copies

ONSITE

2 DOE Richland Operations Office

K. W. Bracken/P. K. Clark

R. E. Gerton/D. R. Elle

78 Pacific Northwest Laboratory

W. J. Bair

C. D. Becker (40)

P. A. Beedlow

L. L. Cadwe 11

C. E. Cushing

D. D. Dauble

D. W. Dragnich

P. A. Eddy

C. E. Elderkin

D. H. Fickeisen

H. Gray

J. M. Hales

H. H. Harty
No. of

Copies

P. C. Hays

S. F. Liebetrau

W. D. McCormack

D. H. McKenzie

D. A. Neitzel

C. A. Newbill

T. L. Page

L. S. Prater

K. R. Price

W. H. Rickard

L. E. Rogers

R. L. Skaggs

J. A. Stottlemyre

J. A. Strand

W. L. Templeton

B. E. Vaughan

D. G. Watson

G. Whelan

R. E. Wildung

Technical Information MH (5)

Publishing Coordination (2) 